UNIVERSIDADE DE SÃO PAULO

FACULDADE DE FILOSOFIA, LETRAS E CIÊNCIAS HUMANAS

DEPARTAMENTO DE LETRAS CLÁSSICAS E VERNÁCULAS

PROGRAMA DE LITERATURA BRASILEIRA

A CONSTRUÇÃO DO AMOR

UMA ANÁLISE DO ROMANCE IAIÁ GARCIA DE MACHADO DE ASSIS

Áriston Moraes Rodrigues

Orientadora: Prof. ${ }^{a}$ Dr. ${ }^{a}$ Cilaine Alves Cunha

VERSÃO CORRIGIDA

SÃo PAULO

2011 


\section{ÁRISTON MORAES RODRIGUES}

\section{A CONSTRUÇÃO DO AMOR}

UMA ANÁLISE DO ROMANCE IAIÁ GARCIA DE MACHADO DE ASSIS

Dissertação de mestrado apresentada ao Programa de Pós-Graduação em Literatura Brasileira da Faculdade de Filosofia, Letras e Ciências Humanas da Universidade de São Paulo como requisito para a obtenção do título de Mestre em Literatura Brasileira.

Orientadora: Prof. ${ }^{a}$ Dr. ${ }^{a}$ Cilaine Alves Cunha

\section{VERSÃO CORRIGIDA}

SÃO PAULO

2011 
À minha mãe 


\section{AGRADECIMENTOS}

Sem o apoio das pessoas que cito em seguida, este trabalho não poderia ter sido elaborado e, por isso, registro aqui os meus agradecimentos: à professora Cilaine Alves Cunha pela orientação e, sobretudo, por partilhar o seu amplo conhecimento e domínio sobre literatura e sociedade oitocentistas; à professora Berta Waldman pelas conversas e atenção dispensada; à Dayane Esteves Nogueira, funcionária do departamento de pósgraduação da FFLCH-USP, pela paciência com a qual atendeu a todas as minhas ligações com dúvidas sobre procedimentos técnicos e acadêmicos; a todos os parentes e amigos que, a despeito da distância física, apoiaram-me e encorajam-me nos momentos difíceis e, dentre tantas pessoas queridas, destaco alguns nomes que, por motivos diversos, atuaram diretamente no meu processo de pós-graduação: Eline Pereira, Diego Maurílio, Martha Pimenta, Nayara Romero, Patrícia Antunes, Tatianne Gonçalves, Wane Amaral, Wellington Migliari e Manuella Miki. Sou extremamente grato pela inestimável ajuda de todos vocês! Agradeço ainda à minha mãe pelo apoio e dedicação de sempre, e também, a companhia e o auxílio do João Eduardo, que compartilhou comigo todos os momentos dessa pós-graduação.

Muito obrigado! 


\section{RESUMO}

Este trabalho analisa como se comportam as personagens femininas do romance Iaiá Garcia, a partir das suas escolhas amorosas, no âmbito do sistema de favor e cooptação do Segundo Reinado. Para tanto, a análise do estado amoroso em contrapartida aos valores da sociedade clientelista ganha destaque neste trabalho, permitindo compreender a oposição entre as duas principais figuras femininas do romance, Estela e Iaiá Garcia. Como o proposto pelo narrador, as duas personagens simbolizam o "passado" e o "futuro" do comportamento social em meados do século XIX e, assim, servem como meio para a discussão, no romance, das relações afetivas intrinsecamente ligadas à questão matrimonial no decurso histórico do Segundo Reinado. Esta análise mostra que essa oposição é uma fórmula encontrada pelo escritor para desacreditar o valor do amor como um sentimento imanente ao homem.

Palavras-chave: amor, interesse, matrimônio, clientelismo, Estela, Iaiá Garcia 


\begin{abstract}
This research analyzes the behaviors of female characters in the novel Iaia Garcia, by looking at their choices related to love issues, within the system of mutual favors and cooptation prevalent in Brazil during the Second Empire period. A contrastive analysis between love and social patronage values is carried out in order to understand the opposition between the two main female characters in the novel, Estela and Iaiá Garcia. According to the novel's narrator, these characters represent the "past" and the "future" of the social behavior in the middle of the nineteenth century, and, thus, they are used as a means to discuss, within the novel, affective relations inextricably linked to issues of marriage during the history of the Second Empire in Brazil. This analysis shows that that opposition is a way used by Machado de Assis to deny the value of love as an inherent human feeling.
\end{abstract}

Keywords: love, interests, marriage, patronage, Estela, Iaiá Garcia 


\section{SUMÁRIO}

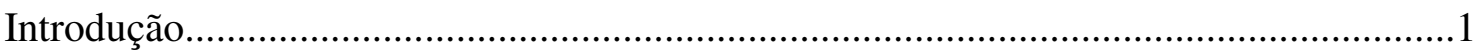

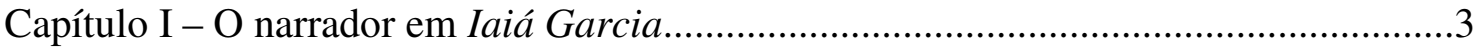

Capítulo II - Estela: a austeridade em defesa da dignidade pessoal.............................27

Capítulo III - Iaiá: a ação racionalmente orientada...................................................53

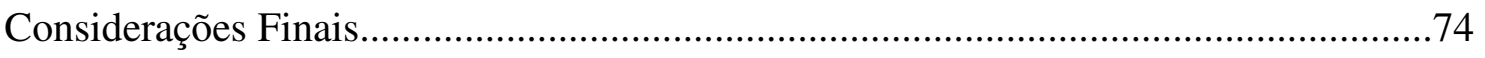

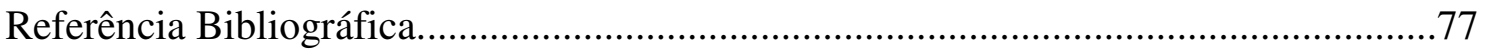




\section{INTRODUÇÃO}

Este trabalho detém-se sobre o romance Iaiá Garcia, procurando analisar em que medida Machado de Assis, ao se debruçar sobre as razões que levam alguns personagens a escolher o seu par amoroso, problematiza o modo de ação e reação das suas criações no interior do sistema de favor e cooptação. Para tanto, a abordagem do matrimônio representa um fator de relevância neste trabalho, porque, por meio da união conjugal, o sistema patriarcal pôde, no decorrer dos tempos, sustentar o elo patrimonial entre as famílias abastadas, reforçando o poder do pater familias. Porém, com a "adaptação do ideário burguês"1 ao sistema clientelista brasileiro, houve um abrandamento desse padrão conjugal, dando liberdade de escolha ao indivíduo. Nesse sentido, ao tratar do desejo e sentimentos das jovens aspirantes ao casamento, Machado faz convergir no romance as "duas naturezas humanas", o que lhe permite discutir as relações humanas na sua criação literária.

$\mathrm{Na}$ conjugação do interesse social e do desejo feminino, o "olhar do narrador"3 machadiano parece "ora desculpar, ora acusar" os comportamento humanos no âmbito do sistema patriarcal, traçando o movimento da sociedade brasileira na sua lenta transição ao longo da segunda metade do século XIX. Assim, o romance Iaiá Garcia, publicado em 1878, discute essas transformações no tempo histórico brasileiro, pois, a trama tem como fio condutor as relações afetivas guiadas pelo poder patriarcal e o clientelismo que imperava na sociedade brasileira. Os pares amorosos da narrativa sofrem a dupla interferência prevista pelo escritor: da força do sistema social e da pulsão íntima, privilegiando, aí, a figura feminina.

Nessa perspectiva, este trabalho destaca a representação da figura feminina em Iaiá Garcia, a fim de analisar a relação entre amor e casamento a partir da oposição entre as duas personagens principais do romance: Estela e Iaiá Garcia; dois perfis femininos

\footnotetext{
${ }^{1}$ Cf. SCHWARZ, Roberto. Ao vencedor as batatas: forma literária e processo social nos inícios do romance brasileiro. 5. ed. São Paulo: Livraria Duas Cidades / Editora 34, 2000. 236 p. (Coleção Espírito Crítico).

${ }^{2}$ MACHADO DE ASSIS. Ressurreição. In: Machado de Assis: obra completa em quatro volumes. Organização Aluizio Leite et al. 2. ed. Rio de Janeiro: Nova Aguilar, 2008. v. 1, p. 235-236. (Fortuna Crítica / Romances).

${ }^{3}$ Cf. BOSI, Alfredo. Machado de Assis: o enigma do olhar. São Paulo: Ática, 1999. 228 p
} 
distintos, como propõe o narrador: uma parece vir do "passado" e a outra ir para o "futuro". Sinalizando essa diferenciação temporal, o narrador descreve o temperamento e o comportamento dessas duas mulheres diante da convenção moral da sociedade do Segundo Reinado, permitindo ao autor avaliar criticamente amor e interesse social.

Dividido em três partes, este trabalho elabora no seu primeiro capítulo uma discussão sobre o ponto de vista ambíguo assumido pelo narrador machadiano neste romance, na busca de esclarecer a tentativa do autor em criar uma forma de evidenciar as contradições das personagens. Para isso, examinar-se-á a descrição da personagem Luís Garcia durante o primeiro capítulo do romance, que explicita as bases da rede social interposta na narrativa. Já no segundo capítulo, a análise se debruça sobre a descrição de Estela, personagem que porta uma noção aguda de sua própria honra e um temperamento austero. Essa postura da personagem, ao longo da narrativa, indica a sua visão do amor como um sentimento imanente ao ser humano e, por isso, contrário às relações de cooptação da sociedade em que vive. Assim, seus princípios morais põemna em conflito com a estrutura social, apontando para a metáfora de que ela seria uma mulher do passado.

No terceiro e último capítulo, o trabalho se detém sobre a personagem de Iaiá Garcia, da qual o narrador descreve o lento amadurecimento desde pequena até a idade adulta. $\mathrm{O}$ acompanhamento desse processo permite-lhe indicar as transformações da garota que, esperta, aprende rapidamente as regras da cooptação e do favor, passando, com isso, a agir racionalmente em nome de seu interesse. O amadurecimento de Iaiá, além de refletir um comportamento em conformidade com o "futuro" social, serve ao narrador como maneira de discutir a relação afetiva dos indivíduos de uma sociedade que se adapta às transformações sociais do final do século XIX. 


\section{CAPÍtUlO I}

\section{O NARRADOR EM IAIÁ GARCIA}

Questão fundamental em Iaiá Garcia, a perspectiva do narrador em terceira pessoa sustenta-se sob uma tênue divisão entre neutralidade e imparcialidade narrativa. Esses dois ângulos, a interseção entre opinar e descrever, torna a compreensão do romance tortuosa, porque o narrador intrometido dispersa seus comentários em meio à imparcialidade narrativa, revelando a neutralidade textual pretendida por ele como um instrumento ainda limitado. No "drama que o livro pretende narrar", apesar da sua participação ativa, enquanto de um ponto de vista onisciente, ele tende a fazer algum esforço para ser imparcial. Nesse aspecto, sua interferência direta na trama do romance aparece moderadamente e com variação desproporcional em relação a cada capítulo.

Interessado em mostrar as peculiaridades do caráter das personagens, pontuando a mobilidade psicossocial de cada uma, ele usa, em primeira instância, o expediente da imparcialidade narrativa como maneira de retratar a vida e comportamentos das suas criaturas. Ao fazer uso desse recurso ele demonstra querer assumir um ponto de vista neutro em relação a elas, das quais se distancia, descrevendo-as objetivamente. Consequentemente, a sua posição tende a assumir o ponto de vista do observador desinteressado, comprometido com a imparcialidade, ainda que esta não seja absoluta, o narrador está em busca da construção de uma personagem capaz de mostrar-se ao leitor por meio do dinamismo de suas ações.

No entanto, essa distância guardada em relação às personagens diminui ao se perceber comentários dispersos ao longo de Iaiá Garcia, quando a proximidade do narrador com a sua criatura ganha espaço no enredo, orientando o entendimento do leitor. Grosso modo, o ponto de vista sobre as personagens sustenta-se por meio da onisciência e de julgamentos morais narrativos, delineando a marca da subjetividade no romance. Os comentários e a onisciência apontam para a instância do narrador como um elemento impositivo. Apesar de tentar omitir o seu ponto de vista, quando se põe a descrever

\footnotetext{
${ }^{4}$ MACHADO DE ASSIS. Iaiá Garcia. Op. cit., p. 514.
} 
imparcialmente, o narrador do quarto romance de Machado de Assis tem certa eleição pessoal por algumas personagens, visto na definição dos seus caracteres. Com isso, observa-se uma sobreposição do estilo narrativo parcial e imparcial na condução do enredo de Iaiá Garcia.

Distribuído em duas partes delimitadas temporalmente pelo fim da Guerra do Paraguai, o romance narra a trajetória de dois envolvimentos afetivos que se interligam na arquitetura social das famílias Garcia e Gomes. Na primeira parte do livro a narração se concentra no envolvimento entre a agregada Estela e o filho da sua protetora Valéria Gomes, Jorge. Marcado pelos preconceitos sociais que Valéria sustenta a todo custo, o enlace afetivo entre os jovens não se consolida, pois Jorge, impelido por seus sentimentos em relação à agregada de sua casa e pelo interesse social de sua mãe, parte para as frentes de batalha na Guerra do Paraguai. O distanciamento dos amantes abre espaço na trama para um segundo momento narrativo, no pós-guerra. Nesse momento, Estela, já casada com outro homem, Luís Garcia, vê a sua enteada, Iaiá Garcia, envolver-se em um relacionamento afetivo com seu antigo amor, Jorge.

No intento de ressaltar essa partição da narrativa, delimitando as transformações socioculturais que a integram, no primeiro capítulo de Iaiá Garcia o leitor é inserido no contexto em que vive a família Garcia. Por meio da descrição do ambiente da casa e seus moradores, o narrador trata de criar o cenário do primeiro núcleo familiar do romance, sobretudo, delimitando os aspectos psicossociais de seu patriarca.

\footnotetext{
Luís Garcia era funcionário público. Desde 1860 elegera no lugar menos povoado de Santa Teresa uma habitação modesta, onde se meteu a si e a sua viuvez. Não era frade, mas queria como eles a solidão e o sossego. A solidão não era absoluta, nem o sossego interrompido; mas eram sempre maiores e mais certos que cá embaixo. Os frades que, na puerícia da cidade, se tinham alojado nas outras colinas, desciam muita vez, - ou quando o exigia o sacro ministério, ou quando o governo precisava da espada canônica, - e as ocasiões não eram raras; mas geralmente em derredor de suas casas não ia soar a voz da labutação civil. Luís Garcia podia dizer a mesma coisa; e, porque nenhuma vocação apostólica o incitava a abrir a outros a porta de seu refúgio, podia dizer-se que fundara um convento em que ele era quase toda a comunidade, desde prior até noviço. ${ }^{5}$
}

A descrição no romance começa por forcejar a imagem de Luís Garcia como um homem socialmente isolado e avesso ao trato social. Esta estilização da personagem já

\footnotetext{
${ }^{5}$ Ibidem, p. 509.
} 
se anuncia nos dois primeiros períodos do excerto que tratam da figura do funcionário público. A função burocrática, que começa a se desenvolver no Brasil em meados do século XIX ${ }^{6}$, representa os incipientes postos de trabalho surgidos, com a Independência do Brasil, a partir da pressão social ocasionada pelo desenvolvimento econômico dos pequenos comerciantes e dos banqueiros brasileiros conscientes do prestígio oriundo de suas atividades. $\mathrm{O}$ aumento crescente do poder político desses estratos econômicos, no seio da sociedade de proprietários rurais, moveu lentamente a expansão de novas classes sociais, alargando o antigo "binômio senhor e escravo", . Com o desenvolvimento comercial das cidades, a camada livre, até então socialmente constituída por agregado ou vendeiro na estrutura da propriedade rural $^{8}{ }^{8}$ aos poucos conseguiu obter vínculos sociais assalariados para se sustentar, possibilitando o seu relativo afastamento do sistema de favor comum e imperativo até o final do Segundo Reinado.

Prescindindo da manifestação pessoal do narrador, a descrição atribui status social à personagem que, como funcionário público, pode ter certa independência financeira. Por meio da renda de um trabalho regulamentado pelo Estado, ele pode se refugiar em uma casa própria, ainda que modesta, no lugar menos povoado do morro da Santa Teresa, na tentativa de evitar a dependência ao patriarca, à qual, no seu passado imediato, ele tivera ligação, como afirma o narrador no início do segundo capítulo: “[...] o pai de Luís Garcia devera alguns obséquios [ao desembargador Gomes] e a quem este prestara outros." ${ }^{9}$ Dessa maneira, o pai de Garcia foi também um homem inserido nas relações clientelistas, comum à história social do país.

Contudo, não interessa ao narrador perscrutar o passado da personagem. O seu interesse recai sobre o autoisolamento de Garcia no morro e, com isso, a geografia da cidade ganha relevo. "As colinas", citadas no texto, metaforicamente, fazem menção à eleição dos frades, do início da colonização do Rio de Janeiro, pelos pontos elevados e ermos da cidade como local para a instalação dos primeiros mosteiros. Essas escolhas refletiam a idealização do afastamento da "labutação civil", pelos clérigos, que apenas

\footnotetext{
${ }^{6}$ Cf. STEIN, Ingrid. Figuras femininas em Machado de Assis. Rio de Janeiro: Paz e Terra, 1984. 146 p. (Coleção Literatura e Teoria Literária).

${ }^{7}$ FAORO, Raymundo. Machado de Assis: a pirâmide e o trapézio. 2. ed. São Paulo: Editora Nacional, 1976. p. 33.

${ }^{8}$ Cf. FRANCO, Maria Sylvia de Carvalho. Homens livres na ordem escravocrata. 3. ed. São Paulo: Livraria Kairós, 1983. 235 p.

${ }^{9}$ MACHADO DE ASSIS. Iaiá Garcia. Op. cit., p. 514.
} 
desciam dos morros para atender alguma demanda pública comum ao sacerdócio, ou ainda, à ligação política relacionada ao poder secular dos homens vinculados à corte imperial na cidade baixa. ${ }^{10}$ Neste espaço, onde fervilha a vida social em seu dinamismo, encontram-se, majoritariamente, os homens públicos, livres e escravos, organizados em torno da ordem civil. Assim, opondo o lugar da sagrada liturgia e o do poder civil, o narrador delimita a diferença espacial da cidade, cujos morros são habitados por moradores em busca de solidão e tranquilidade. Trata-se de um local onde as querelas oriundas das relações sociais pouco afetariam a privacidade de seus lares. Com base nesse mesmo ideal, Luís Garcia, ao mudar-se para Santa Teresa, funda para si “[...] um convento em que ele era quase toda a comunidade, desde prior até noviço."11 Nesse aspecto, as descrições do narrador, associando a vida de Luís Garcia à dos primeiros frades da cidade, constituem um elemento importante para se compreender o desejo da personagem em busca do isolamento social.

Porém, antes que essa comparação personifique a personagem delimitada apenas pelo veio de uma necessidade de reclusão social, o narrador pondera: “A solidão [de Luís Garcia em Santa Teresa] não era absoluta, nem o sossego interrompido [sic]; mas eram sempre maiores e mais certos que cá embaixo." "12 Sua interferência altera o ritmo neutro da descrição do enredo, propondo a comparação entre a vida da personagem no morro e na baixada fluminense. Na primeira parte da frase citada, o narrador intrusivo sentencia o caráter relativo da solidão absoluta de Garcia e, na segunda parte, o ponto de vista do discurso se altera por meio do uso da expressão "que cá embaixo". Por meio dela é possível perceber o deslocamento do nível textual do campo objetivo para o subjetivo na voz do narrador. Sem usar qualquer pronome ou alusão direta à pessoa do discurso, ele transcreve um comentário disperso na exposição do enredo. Usando o discurso

\footnotetext{
10 "Os religiosos que chegaram ao Rio de Janeiro ocuparam os locais mais altos da cidade. Os jesuítas foram os primeiros a chegar, em 1567, e se instalaram no morro do Castelo, onde fundaram o seu primeiro colégio. Os beneditinos, que chegaram no ano de 1589, ocuparam o morro de São Bento, e edificaram no morro o seu mosteiro, consagrando a igreja a Nossa Senhora de Montserrat. Os franciscanos chegaram em 1592 e alojaram-se na ermida de Santa Luzia, dividindo com os jesuítas as bases do morro do Castelo, onde permaneceram por 15 anos. Quando os franciscanos ergueram o seu próprio convento, a eles foi oferecido o morro de Santo Antônio. Independente da ordem religiosa a que pertencessem, os sacerdotes frequentemente se envolviam em questões políticas e militares referentes à Coroa portuguesa." ROMANCES EM HIPERTEXTO: Iaiá Garcia: Banco de dados preparado por Marta de Senna. In: FUNDAÇÃO CASA DE RUI BARBOSA. Machado de Assis.net: no ar desde 2007. Disponível em: <http://www.machadodeassis.net/hiperTx_romances/obras/iaiagarcia.htm>. Acesso em: 9 Jan. 2011.

${ }^{11}$ MACHADO DE ASSIS. Iaiá Garcia. Op. cit., p. 509.

${ }^{12}$ Ibidem, p. 509, grifo nosso.
} 
indireto livre, o narrador disfarça a sua voz, colocando-se no pensamento da personagem para falar do ponto de vista do outro. Assim, com a expressão "cá embaixo", o narrador identifica o lugar de onde fala, distante das colinas, onde a cidade vive os enlaces sociais comuns aos centros urbanos e, também, afirma e reforça o entendimento da vida de Luís Garcia como distante da clausura social.

Essa assertiva da diferença de modos de vida no Rio de Janeiro abre espaço para o narrador também elencar a diferença entre a almejada vida pacata da personagem e a de retiro dos antigos frades da cidade. Estes sacerdotes, isolados nos conventos, abrigo para a vida espiritual, desciam das colinas para legitimar os atos do Estado civil com o poder da sua "espada canônica", ou quando mandava o "sacro ministério", sem, geralmente, terem a sua privacidade nos morros incomodada pela voz civil. O envolvimento dos frades com o mundo profano limitava-se ao convívio no espaço da Corte, na cidade baixa, ficando o convento usualmente restrito ao sacerdócio. Já Luís Garcia, apesar de habitar um simulacro cristão distante da Corte, não tinha vocação religiosa. Os seus esforços para se afastar da vida social poderiam lhe render certa tranquilidade, mas não a paz de um lar clerical.

Mesmo distanciado fisicamente do centro de gravitação social fluminense, por meio de recursos próprios, Luís Garcia faz parte de um contingente de homens que mantêm relações sociais mínimas. A sua posição social mantém vínculos do homem mundano em busca da sobrevivência e acaba por trazer à sua porta a "voz da labutação civill", com seus obséquios oferecidos e prestados. Apesar de seus esforços para fugir do contato com a sociedade, o seu convívio social é reduzido, mas não cessa. A solidão no morro, que para os frades representa a clausura, para ele significa uma tentativa de refúgio por meio da distância espacial, que apenas lhe oferece uma redução do potencial de contato com as relações travadas na cidade.

A intromissão do narrador, pontuando a inquietação das relações sociais da cidade baixa, traduz as transformações sociais ambientadas no Brasil a partir da segunda metade do século XIX. Historicamente, esta é a época na qual o Rio de Janeiro inicia a sua urbanização e, também, vê surgir e multiplicarem-se as camadas sociais intermediárias, ligadas “[...] sobretudo ao pequeno comércio, às atividades burocráticas, 
jornalísticas, literárias e políticas." ${ }^{, 13}$ No meio desses novos matizes sociais, abrem-se as perspectivas para homens como Luís Garcia, sem bens, propriedades ou tradição familiar. Com profissão definida, mesmo sem lhe garantir grandes somas, ele possui meios para se distanciar do sistema de favor e cooptação, do arbítrio e caprichos dos poderosos. ${ }^{14}$ A sua vida diferencia-se do rumo de muitos homens livres associados aos ricos proprietários rurais em busca de proteção e recursos pessoais. ${ }^{15}$ No entanto, ele não abre mão dessa estrutura, dando continuidade ao processo social ao prestar e receber obséquios. Dessa maneira, a construção de uma personagem solidamente refratária ganha um contorno ambíguo no qual a conveniência social sobressai ao desejo de Garcia, mostrando uma conduta pessoal obscura, a qual o narrador continua a descrever:

\begin{abstract}
No momento em que começa essa narrativa, tinha Luís Garcia quarenta e um anos. Era alto e magro, um começo de calva, barba rapada, ar circunspecto. Suas maneiras eram frias, modestas e corteses; a fisionomia um pouco triste. Um observador atento podia adivinhar por trás daquela impassibilidade aparente ou contraída as ruínas de um coração desenganado. Assim era; a experiência, que foi precoce, produzira em Luís Garcia um estado de apatia e ceticismo, com seus laivos de desdém. $O$ desdém não se revelava por nenhuma expressão exterior; era a ruga sardônica do coração. ${ }^{16}$
\end{abstract}

Luís Garcia não representa o tipo de homem elegante, afortunado, como Jorge. Este possuía "[...] bigode negro e basto, obra comum da natureza e do cabeleireiro [...]", que lhe conferia "[...] ao rosto a expressão viril [...]"17 Ao contrário, a aparência do primeiro deles ganha traços de uma figura mediana, avessa a modismos e convenções do homem da classe dominante. Quadragenário, Luís Garcia trazia a barba raspada e possuía ar circunspecto e postura social fria, mas também cortês. A metáfora da "mediania" aos poucos compõe o traço caricatural de homem ascético, à qual acrescenta-se um pouco de tristeza. Nessa mistura, o pouco se torna muito quando o narrador novamente formula um irônico juízo de valor, destacando a percepção de haver, por trás da fisionomia de Luís Garcia mais que severidade, havia supostamente o sofrimento acarretado por um passado misterioso, como o dos heróis românticos atormentados.

\footnotetext{
${ }^{13}$ STEIN, Ingrid. Op. cit., p. 19

${ }^{14}$ Cf. SCHWARZ, Roberto. Op. cit.

${ }^{15}$ Cf. FRANCO, Maria Sylvia de Carvalho. Op. cit.

${ }^{16}$ MACHADO DE ASSIS. Iaiá Garcia. Op. cit., p. 509, grifo nosso.

${ }^{17}$ Ibidem, p. 517.
} 
Os sentimentos reclusos da personagem são avaliados, então, pela óptica intrusiva do narrador que, ao nomeá-los, substitui a escolha semântica enxuta que vinha usando na descrição da personagem pela empolada oração: “Um observador atento podia adivinhar por trás daquela impassibilidade aparente ou contraída as ruínas de um coração desenganado." ${ }^{18}$ Apelando ironicamente ao romantismo de traços melodramáticos, a sentença empregada pelo narrador insinua o sentimento oculto da personagem. A causa derradeira do comportamento avesso à sociedade de Luís Garcia estaria diretamente ligada a algum desgosto ocorrido no passado; alguma questão existencial que, como elemento motriz da sua vida, teria desencadeado o seu distanciamento social. Já de um ponto de vista neutro, o narrador afirma que Garcia tivera sim um desengano afetivo, uma experiência de vida precoce, sugerindo ao leitor um acontecimento impactante e indelével na alma da personagem. Fonte da conduta cética e apática, ele perduraria na figura taciturna de Garcia ao longo dos seus quarenta e um anos de vida, sustentandolhe certo rancor pela condição humana. Nódoa do tempo, esse sentimento não desenvolve questionamentos e nem exterioriza seu desprezo pela humanidade, recluso como uma "ruga sardônica do coração". À sociedade, Luís Garcia somente se expressa por meio de gestos calculados e cordiais, sem lhe mostrar uma alma profundamente abalada.

Esse aspecto subjetivo da personalidade de Garcia, sua dor existencial profunda, no final do primeiro capítulo, é retomado e explicitado pelo narrador: "nenhuma ambição, cobiça ou peleja vinha toldar-lhe a serenidade da alma. A última dor séria que tivera foi a morte da esposa, ocorrida em 1859, meses antes de ir-se ele esconder em Santa Teresa." ${ }^{19}$ Do ponto de vista onisciente, o narrador confirma a tranquilidade buscada por Garcia no morro, como consequência do abalo afetivo sofrido pela personagem para, em seguida, comentar ironicamente: "O tempo, esse químico invisível, que dissolve, compõe, extrai e transforma todas as substâncias morais, acabou por matar no coração do viúvo, não a lembrança da mulher, mas a dor de a haver perdido." ${ }^{20}$ Dessa fala, podese concluir que Garcia não sofre com a perda da esposa; situação ironicamente concluída, mais adiante no texto, pelo narrador.

\footnotetext{
${ }^{18}$ Ibidem, p. 509, grifo nosso.

${ }^{19}$ Ibidem, p. 514.

${ }^{20}$ Ibidem, p. 514.
} 
Importa dizer que as lágrimas derramadas nessa ocasião honraram a esposa morta, por serem conquista sua. Luís Garcia não casara por amor nem interesse; casara porque era amado. Foi um movimento generoso. A mulher não era de sua mesma índole; seus espíritos vinham de pontos diferentes do horizonte. Mas a dedicação e o amor da esposa abriram nele a fonte da estima. Quando ela morreu, viu Luís Garcia que perdera um coração desinteressado e puro; consolou-o a esperança de que a filha havia herdado uma parcela dele. ${ }^{21}$

Luís Garcia não casou "por amor nem por interesse". Fleumático e "descrente" na sociedade, como descreve o narrador, seu enlace foi motivado pelo amor que o outro tem por ele. Ironicamente, o "movimento generoso" de sua parte em ceder ao casamento, mesmo sem amar, tinha por objetivo os cuidados e "a dedicação" oferecida pela futura esposa. $\mathrm{O}$ amor dessa mulher apaixonada e desinteressada alimentou nele o sentimento de amor-próprio, máscara do egoísmo, sem lhe alterar, ao longo do convívio mútuo, os sentimentos, a face do homem preocupado apenas consigo mesmo. Esse traço de personalidade impede-o de ver a esposa de uma maneira afetiva e apenas após a morte da mulher, quando o narrador informa que Garcia viu a perda de um "coração desinteressado e puro", ele reconhece nela algum valor pessoal. Em outras palavras, na visão de Garcia, da relação de estima nutrida pela esposa ele apenas perdera a "dedicação" de uma mulher apaixonada, mas o consolava a esperança da Iaiá vir a herdar esse traço da personalidade da mãe, diminuindo o valor dessa perda.

A Garcia a conveniência de ter uma mulher dedicada impõe-se como condição primeira na relação matrimonial. Assim, a ironia do narrador em relação a tropo romântico, ao dizer que a personagem tinha em si as "ruínas de um coração desenganado", não passa de um gracejo com o lugar comum do homem de coração partido. A idealização romântica em relação à subjetividade, destacando-se nela a "dor da alma",22, é tripudiada. Garcia não sofria por um grande amor perdido, apenas cultua, em uma casa erma onde recebe "poucos amigos", a "melancolia da solidão",23. Dessa maneira, Machado de Assis aplica no modo de ser da personagem o culto romântico do sofrimento que, incorporado à cultura, tornara-se um clichê e, por isso, o apego à dor já

\footnotetext{
${ }^{21}$ Ibidem, p. 514.

${ }^{22}$ Cf. STAEL-HOLSTEIN, Anne Louise Germaine de. De la littérature : considérée dans ses rapports avec les instituitions sociales. [Paris: s.n.], 1800.398 p. Disponível em: $<$ http://books.google.com.br/books?id=EnAGAAAAQAAJ\&printsec=frontcover\&dq=De+La+litt\%C3\% A9rature+:+consid\%C3\% A9r\%C3\%A9e+dans+les+rapports+avec+les+institutions+sociales\&hl=ptBR\&ei=1FETen2DozJcZvkpYEO\&sa=X\&oi=book_result\&ct=result\&resnum $=2 \& v e d=0 C C 4 Q 6 A E w A Q \# v=$ onepa ge\&q\&f=false $>$ Acesso em: 4 Fev. 2011.

${ }^{23}$ MACHADO DE ASSIS. Iaiá Garcia. Op. cit., p. 510.
} 
estava esgarçado. O narrador, por sua vez, ao mostrar essa veneração privada do sentimento da personagem e a sua vida social distante da clausura, destaca o padecimento humano como tributo comum ao homem, que na sociedade moderna, teria de se haver, além de seus sentimentos, com os conflitos da experiência social. Na caracterização de Luís Garcia, essa perspectiva coloca o homem livre diante da necessidade do trabalho e das determinações sociais em confronto com suas motivações subjetivas.

\begin{abstract}
Por fora, havia só a máscara imóvel, o gesto lento e as atitudes tranqüilas. Alguns poderiam temê-lo, outros detestá-lo, sem que merecesse execração nem temor. Era inofensivo por temperamento e por cálculo. Como um célebre eclesiástico, tinha para si que uma onça de paz vale mais que uma libra de vitória. Poucos lhe queriam deveras, e esses empregavam mal a afeição, que ele não retribuía com afeição igual, salvo duas exceções. Nem por isso era menos amigo de obsequiar. Luís Garcia amava a espécie e aborrecia o indivíduo. Quem recorria a seu préstimo, era raro que não obtivesse favor. Obsequiava sem zelo, mas com eficácia, e tinha a particularidade de esquecer o benefício, antes que o beneficiado o esquecesse. $^{24}$
\end{abstract}

Por isso, Garcia afivela à face uma "máscara imóvel" com expressões modestas e frias. Valia-lhe mais não possuir vantagens a se indispor socialmente para obtê-las e, por não gostar do favor, "ele não retribuía com afeição igual" àqueles que lhe queriam ("salvo duas exceções", que mais à frente o leitor fica sabendo tratarem-se da filha e de Raimundo). Assim, de volta ao mesmo paralelo do início do capítulo, quando a vida de Garcia é comparada à dos frades, o narrador parodia o ditado católico: "E sabeis que uma onça de obra, feita no meio das trevas e securas com a ponta do espírito, vale mais que cem libras feitas entre consolações e devotos sentimentos. ${ }^{, 25}$ Traduzindo a estrutura sintática, tem-se que: uma luta árida, com empenho do espírito, vale mais que a acomodação proposta pelo reconforto da palavra ou pela afeição despendida. Por meio desse procedimento jocoso, o narrador alcança na figura da personagem a expressão de

\footnotetext{
${ }^{24}$ Ibidem, p. 509-510.

25 "A referência parece adaptada de uma frase de São Francisco de Sales, citada pelo Padre Manuel Bernardes (1644-1710), em Luz e Calor. [...] Ainda não foi localizada a referência na obra de São Francisco de Sales (1567-1622), cuja obra mais importante é a Filoteia ou Introdução à vida devota, conjunto de conselhos e doutrinas destinados ao amadurecimento da fé católica e da devoção dos fiéis." ROMANCES EM HIPERTEXTO: Iaiá Garcia: Banco de dados preparado por Marta de Senna. In: FUNDAÇÃO CASA DE RUI BARBOSA. Machado de Assis.net: no ar desde 2007. Disponível em: $<$ http://www.machadodeassis.net/hiperTx_romances/obras/iaiagarcia.htm>. Acesso em: 9 Jan. 2011.
} 
seu esforço para se autopreservar, em sendo passiva, ao afirmar que para ela "[...] uma onça de paz vale mais que uma libra de vitória." ${ }^{26}$

A máxima do narrador reflete e reafirma a repulsa da personagem pelos inconvenientes e desgastes pessoais gerados pelo sistema de cooptação no seu contexto social de funcionário público de escalão médio. A conquista de algum obséquio poderia torná-lo devedor de algum favor, desagradando-lhe este procedimento social, mas "nem por isso era menos amigo de obsequiar". Àqueles que recorriam aos seus préstimos "obsequiava sem zelo, mas com eficácia", esquecendo-se do "benefício" prestado antes mesmo do esquecimento pelo "beneficiado". Essa particularidade do caráter de Garcia pode gerar o espanto do leitor, porque a vida da personagem é descrita por meio do desequilíbrio entre o ato de prestar um favor e seu subsequente esquecimento. Em meio à natureza da relação clientelista, o narrador diz que Luís Garcia atende aos pedidos de obséquios como se nada quisesse ou esperasse em troca, situação incomum nesse gênero de transação. No entanto, esse comportamento aparentemente modesto e solícito, sempre preferindo "uma onça de paz", se contradiz, mais adiante no romance, porque, de bom grado, ele aceita o dote dado à sua filha como "benefício" prestado por Valéria.

O súbito esquecimento dos benefícios prestados por Luís Garcia aparece no enredo como um mecanismo de suposta fuga da realidade clientelista. Ele conhece e está inserido na totalidade dos problemas da sociedade, tem expectativas de conquistar algum benefício pessoal, no entanto, prefere agir como se as relações de dependência não afetassem a sua vida. Visto na sua "máscara imóvel" e em sua indiferença e contrariedade ao sistema de cooptação e favor, o seu comportamento parece estar acima da mundanidade do homem médio. Observando-o, no entanto, em ação, no convívio social, ele se mostra contraditório, em um misto de interesse e conveniência.

Ao omitir o interesse do funcionário público em prestar um obséquio sem contar com a contrapartida do préstimo, o narrador deixa em suspenso o comportamento da personagem, como faz com a informação sobre quem seriam as suas duas afeições na vida. Tentando afastar-se das suas criações, ele prefere deixar que parte do comportamento das personagens seja a fonte da compreensão do leitor, não obstante, ele, por vezes, assuma o pensamento da sua criação, ou mesmo a critique. Ao final, sua

\footnotetext{
${ }^{26}$ MACHADO DE ASSIS. Iaiá Garcia . Op. cit., p. 509.
} 
intenção é desvendar a psicologia de cada uma de suas personagens aos olhos do leitor. Com esse intuito, o narrador volta-se a descrever a vida de Luís Garcia em sua casa, seus modos e espaço físico-social, ampliando a percepção sobre a personagem.

[Regadas as plantas do quintal], [...] recolhia-se e ia trabalhar antes do almoço, que era às oito horas. Almoçado, descia a passo lento até à repartição, onde, se tinha algum tempo, folheava rapidamente as gazetas do dia. Trabalhava silenciosamente, com a fria serenidade do método. Fechado o expediente, voltava logo para casa, detendo-se raras vezes em caminho. ${ }^{27}$

Sucessivamente suas atividades cotidianas são descritas enfatizando sua maneira sistemática e metódica de agir, como um burocrata. Na descrição do narrador, nada parece deslocar ou afligir a rotina de Garcia. Seu cotidiano de horários estritos e atividades diárias indica a monotonia de um sujeito sem grandes aspirações e ambições. O ritmo mecânico de suas atividades ilustra ainda o desinteresse do homem pela ação social, ao mesmo tempo em que confere o tom realista da narração, aludindo a aspectos da vida prosaica no romance.

São aspectos que não se prendem aos conflitos centrais, mas também não desdizem deles, nem da verossimilhança externa - uma disposição ao mesmo tempo solta e unificada, contingente e necessária, de que depende a poesia do romance realista e que neste sentido contam entre os seus elementos formais. Não falta nem mesmo a prova dos nove, o dó de peito deste equilíbrio, que é a incorporação ocasional e por assim dizer fluente de algum grande episódio da história pátria [a Guerra do Paraguai] à trama da ficção, oportunidade em que a forma literária presume abertamente ser a forma da realidade. ${ }^{28}$

A partir desta argumentação, pode-se inferir que Luís Garcia difere sensivelmente das anteriores personagens machadianas. Elencando Félix em Ressurreição, Estevão e Luís Alves em A mão e a luva, e Estácio em Helena, têm-se uma galeria de homens representantes de estratos sociais dominantes, personificados por meio de seus títulos e/ou pelo seu grau de bacharel. São homens em torno dos trinta anos de idade, que têm à disposição o tempo livre, pois estão distantes do labor do dia-a-dia; o ócio era-lhes um privilégio e distinção de homem de posses. O trabalho, como no caso de Jorge em Iaiá Garcia, ainda representante desse núcleo, ocupa a mínina parte do tempo livre, "apenas o bastante para ter o nome no portal do escritório e no almanaque de Laemmert." 29

\footnotetext{
${ }^{27}$ Ibidem, p. 510.

${ }^{28}$ SCHWARZ, Roberto. Op. cit., p. 154-155.

${ }^{29}$ MACHADO DE ASSIS. Iaiá Garcia . Op. cit., p. 518.
} 
Figura de exceção, Estevão, em A mão e a luva, representa o "bacharel proletário",30 que necessita do emprego para sobreviver. Porém, a despeito da sua origem humilde, o narrador apenas usa a referência ao trabalho para reforçar o sofrimento amoroso do jovem. Vivendo um amor incorrespondido por Guiomar, ele se ausenta “[...] uma inteira e comprida semana [...] [do] escritório onde trabalhava [...]”31 e da sociedade por não conseguir suportar a dor da paixão. "Por alto [...] [Estevão] pensou três vezes em morrer, duas em fugir à cidade, quatro em ir afogar a sua dor mortal naquele ainda mais mortal pântano de corrupção em que apodrece e morre tantas vezes a flor da mocidade.”32 $\mathrm{O}$ amor nutrido por Guiomar era maior e mais intenso que sua vida social e, romanticamente estilizado, o jovem, como os outros protagonistas masculinos, tem a profissão e o trabalho à margem de si.

Por sua vez, Luís Garcia representa uma personagem de relevo na série dos quatro romances iniciais de Machado de Assis, porque possui uma ocupação social com afazeres e rotinas características e verossímeis ao cidadão comum do século XIX. Suas preocupações parecem estar voltadas para questões da vida prática e mediana, fugindo da óptica ultraromantizada de um Estevão, ou da vaidade de tantas outras personagens oriundas da camada abastada. Garcia é descrito como um homem de classe média, que, a despeito de possuir um trabalho para sobreviver, ainda se vê rodeado pelas relações de cooptação da antiga estrutura proprietária, das quais pretende se manter distante, mas delas se vale ou mesmo as reproduz em sua vida. Assim, a descrição da sua rotina dentro do lar explora melhor esse posicionamento ambíguo.

\footnotetext{
Ao chegar a casa [após o expediente], já o preto Raimundo lhe havia preparado a mesa, - uma mesa de quatro a cinco palmos -, sobre a qual punha o jantar, parco em número, medíocre na espécie, mas farto e saboroso para um estômago sem aspirações nem saudades. Ia dali ver as plantas e reler algum tomo truncado, até que a noite caía. Então, sentava-se a trabalhar até às nove horas, que era a hora do chá. ${ }^{33}$
}

No intuito de expor a posição social de Luís Garcia, o narrador aprofunda a descrição de sua casa também por meio de índices que criam a ilusão de realidade. ${ }^{34}$ Descrita em detalhes contingenciais, a mesa cria a ilusão de realidade no enredo, prestando-se a

\footnotetext{
${ }^{30}$ Cf. FAORO, Raymundo. Op. cit.

${ }^{31}$ MACHADO DE ASSIS. A mão e a luva. Op. cit. p. 356.

${ }^{32}$ Ibidem, p. 356.

${ }^{33}$ Idem, Iaiá Garcia. Op. cit., p. 510, grifo nosso.

${ }^{34}$ Cf. SCHWARZ, Roberto. Op. cit.
} 
reforçar as características de poucas ambições e aspirações, como o seu jantar "parco em número, medíocre na espécie”. Os desejos de Luís Garcia não vão além do limite de uma vida confortável e segura, sem ostentação ou extravagância. Nesse sentido, a "mediocridade" da sua refeição contribui imageticamente com o ritmo de vida insosso.

Metaforicamente, o narrador diz que Garcia ocupa a posição de pequeno burguês de ambição e aspirações médias, de vida uniforme e conformada com o pouco que the chega às mãos. O seu passado, independentemente de como tivera sido, não lhe traz nenhuma lembrança ou agitação da alma capaz de mover a sua existência em direção a um ideal. Apoiada na máxima de sempre valer mais "uma onça de paz" à vitória, a regularidade imprimida na vida da personagem torna-se um elemento essencial como caracterização do homem mediano, abstraído de elementos políticos ou de discussões sociais. Com uma existência alienada, ele segue a sua rotina apática e reconfortante.

\begin{abstract}
Não somente o teor da vida tinha essa uniformidade, mas também a casa participava dela. Cada móvel, cada objeto, - ainda os ínfimos - parecia haver-se petrificado. A cortina, que usualmente era corrida a certa hora, como que se enfadava se lhe não deixavam passar o ar e a luz à hora costumada; abriam-se as mesmas janelas e nunca outras. A regularidade era o estatuto comum. E se o homem amoldara as cousas a seu jeito, não admira que amoldasse também o homem. ${ }^{35}$
\end{abstract}

Sem se demorar sobre cada móvel da casa, mas afirmando que cada qual legitima o estilo metódico de Garcia, o narrador se detém no movimento das cortinas. Dando vida ao objeto inanimado, a cortina, numa prosopopeia, enfada-se por não cumprir o ritual de sua abertura diária. A casa se torna uma extensão da personalidade do seu proprietário. Cada espaço, cada móvel, cada objeto, está sob a influência do ritmo metódico e estrito da vida de Luís Garcia. O movimento coordenado entre a regularidade de comportamento da personagem e o mundo a sua volta mostra-se esquemático, monótono, assegurando uma vida sem transtornos pessoais, mediana e conformista. Essa atmosfera torna-se mais evidente quando o narrador desenvolve o tipo de relação existente entre Garcia e o seu serviçal.

Raimundo parecia feito expressamente para servir Luís Garcia. Era um preto de cinquienta anos, estatura mediana, forte, apesar de seus largos dias, um tipo de africano, submisso e dedicado. Era escravo e livre. Quando Luís Garcia o herdou de seu pai, - não avultou mais o espólio, - deu-lhe logo carta de liberdade. Raimundo, nove anos mais velho que o senhor, carregara-o ao

\footnotetext{
${ }^{35}$ MACHADO DE ASSIS. Iaiá Garcia. Op. cit., p. 510.
} 
colo, e amava-o como se fora seu filho. Vendo-se livre, pareceu-lhe que era um modo de o expelir de casa, e sentiu um impulso atrevido e generoso. Fez um gesto para rasgar a carta de alforria, mas arrependeu-se a tempo. Luís Garcia viu só a generosidade, não o atrevimento; palpou o afeto do escravo, sentiu-lhe o coração todo. Entre um e outro houve um pacto que para sempre os uniu.

- És livre, - disse Luís Garcia -; viverás comigo até quando quiseres.

Raimundo foi dali em diante um como espírito externo de seu senhor; pensava por este e refletia-lhe o pensamento interior em todas as suas ações, não menos silenciosas que pontuais. Luís Garcia não dava ordem nenhuma; tinha tudo à hora e no lugar competente. Raimundo, posto fosse o único servidor da casa, sobrava-lhe tempo, à tarde, para conversar com o antigo senhor, no jardinete, enquanto a noite vinha caindo. Ali falavam de seu pequeno mundo, das raras ocorrências domésticas, do tempo que devia fazer no dia seguinte, de uma ou outra circunstância exterior. Quando a noite caía de todo e a cidade abria os seus olhos de gás, recolhiam-se eles a casa, a passo lento, à ilharga um do outro. ${ }^{36}$

A caracterização do narrador não poupa palavras ao descrever a relação de Luís Garcia e seu empregado. Raimundo é tratado por Garcia como propriedade adquirida há longa data. Escravo doméstico da família, chegou a embalar Luís quando criança e, quinquagenário, continua forte, "um tipo de africano, submisso e dedicado". A descrição do narrador remete à condição do homem afrodescendente que, submetido à violência da escravidão, atende seu senhor e proprietário com dedicação forjada pelo regime escravocrata. Nesse sentido, a fala do narrador, no início da citação, afirmando que Raimundo parecia feito para servir Garcia, ironiza o comportamento do funcionário público ao vê-lo usando do mesmo expediente de exploração de um proprietário.

Assim, passados anos na casa do antigo senhor como escravo doméstico, Raimundo fez parte do "espólio" paterno de Luís Garcia, como reforça o narrador em discurso direto, o qual, supostamente, Garcia, adulto e incorporando a vida do homem de estrato médio, vem mudar ao conceder a alforria a Raimundo, que passa, então, à condição de "escravo e livre". Nesta expressão aspada, o paradoxo ironiza e evidencia a alforria como um instrumento vazio de sentido, porque ela não muda a condição de Raimundo: alforriado, mas privado de liberdade. Literalmente sem eira nem beira e qualquer perspectiva futura, ao ver-se expelido da casa, e por extensão da família à qual serviu por toda a vida, o escravo, em um momento de revolta e impulsivamente, insinua rasgar a carta que o "liberta" e ao mesmo tempo lhe retira o seu único abrigo.

\footnotetext{
${ }^{36}$ Ibidem, p. 510.
} 
Dessa atitude de Raimundo, o narrador, em discurso indireto livre, afirma que Luís Garcia "viu só a generosidade, não o atrevimento", evidenciando a afirmação de superioridade de Luís enquanto senhor. Afinal, a atitude de ver apenas a generosidade de Raimundo, mas fazendo alusão à situação como um atrevimento, comprova a incorporação pelo funcionário público, mesmo sendo ele relativamente desprivilegiado na sociedade, da óptica patriarcal. No jogo político entre as forças sociais em luta, ele não se une a um possível aliado, o escravo completamente desprivilegiado; pelo contrário, reforça o vínculo de exploração, conforme afirma o narrador: "Raimundo, posto fosse o único servidor da casa, sobrava-lhe tempo à tarde." Com isso, Machado de Assis destaca como o cidadão médio, nos seus atos e pensamentos, reproduz o sistema escravocrata.

Simpático a Raimundo, o narrador, pouco adiante no enredo, volta a essa questão da vida da personagem como serviçal da casa de Garcia, reafirmando a usurpação do trabalho escravo. Na cena, Raimundo brinca com a filha de Luís no quintal da casa:

\footnotetext{
- Raimundo - dizia esta -, você gosta de santo de comer?

Raimundo empertigava o corpo, abria um riso, e dando aos quadris e ao tronco o movimento de suas danças africanas, respondia cantarolando:

- Bonito santo! santo gostoso!

- E santo de trabalhar?

Raimundo, que já esperava o reverso, estacava subitamente, punha a cabeça entre as mãos, e afastava-se murmurando com terror:

- Eh... eh... não fala nesse santo, Iaiá! não fala nesse santo!

- E santo de comer?

- Bonito santo! santo gostoso!

E o preto repetia o primeiro jogo, depois o segundo, até que Iaiá, aborrecida, passava a outra coisa. ${ }^{37}$
}

O jogo consiste em uma espécie de farsa burlesca, na qual Raimundo desdenha o "santo de trabalhar" e, metaforicamente, deixa clara a sua posição diante da condição de escravo e "único servidor", sobrecarregado pelo trabalho doméstico da casa dos Garcia. Metaforicamente, ele diz à filha de Garcia que seria melhor não falar de labor em um local onde ele está sempre assoberbado com afazeres.

Contudo, Luís Garcia ignora os sentimentos do antigo escravo doméstico, visto como um dependente em condição de "espólio" testamental, e sua ameaça de revolta. Raimundo é a sua segunda afeição na vida - como mais adiante no romance informará o

\footnotetext{
${ }^{37}$ Ibidem, p. 512.
} 
narrador - e dele o senhor apenas vê a generosidade. O escravo o embalara quando criança e vivera com ele sob o mesmo teto muito anos. Quando, então, Raimundo ameaça rasgar a sua carta de alforria, Garcia somente vê uma relação permeada de carinho do escravo, abstraída da dependência social. Ao dizer a Raimundo que fique na casa, ele reafirma as antigas relações de favor e cooptação da cultura patriarcal. Paradoxalmente "escravo e livre", Raimundo segue sua rotina de vida na velha conhecida casa do senhor, sem usufruir da sua liberdade enquanto legítima independência pessoal.

[Com o cair da noite], Raimundo acendia as velas, ia buscar a marimba, caminhava para o jardim, onde se sentava a tocar e a cantarolar baixinho umas vozes de África, memórias desmaiadas da tribo em que nascera. $\mathrm{O}$ canto do preto não era de saudade; nenhuma de suas cantilenas vinha afinada na clave pesarosa. Alegres eram, guerreiras, entusiastas; por fim calava-se. $\mathrm{O}$ pensamento, em vez de volver ao berço africano, galgava a janela da sala em que Luís Garcia trabalhava e pousava sobre ele como um feitiço protetor. Quaisquer que fossem as diferenças civis e naturais entre os dois, as relações domésticas os tinham feito amigos. ${ }^{38}$

$\mathrm{Na}$ casa de Garcia, Raimundo ainda mantém alguns hábitos antigos, como "cantarolar baixinho umas vozes da África"; e, se por um lado, como informa a descrição, esse costume não representa a saudade de uma época distante, por outro, ele afirma a força de resistência contra a perda de seus laços de origem. O empregado preserva os costumes de sua nação, suas crenças e seus valores íntimos, mesmo estando em condição adversa ao modo de sua vida na África. As vozes alegres e guerreiras cantadas por Raimundo preservam a memória do seu povo. Nessa interpretação, o narrador revisita o movimento romântico, valorizando na personagem a força da tradição de origem como fonte inspiradora, mas evitando-lhe o clamor nacionalista, inclusive negando a ideia de "banzo". As cantilenas de Raimundo não instigam tristeza e sofrimento, como não se voltam à expressão da dor, como certo romantismo. Suas músicas são fonte de inspiração; alegres e guerreiras, são parte da história do afrodescendente que luta interiormente para defender a memória ancestral.

Não obstante, o narrador termina a descrição do vínculo entre Raimundo e Garcia, afirmando que "quaisquer que fossem as diferenças civis e naturais" "as relações domésticas os tinham feito amigos". A voz narrativa explicita a proposição clara de

\footnotetext{
${ }^{38}$ Ibidem, p. 511.
} 
haver entre eles uma relação calcada no "binômio senhor e escravo",39, e, assim, nada mudara na vida de ambos depois da carta de alforria. Ao ofertar a sua casa como suposto "abrigo" para Raimundo, Luís Garcia troca proteção por serviços domésticos. O "antigo escravo doméstico" serve-lhe de mordomo em troca de proteção, casa, e subsistência, e, ao final, essas ocupações não alteram a antiga condição social de Raimundo. Irônico, o narrador já havia dito antes de iniciar a descrição que "Raimundo parecia feito expressamente para servir Luís Garcia." ${ }^{40}$

A narração, que em princípio parece recontar a história de uma amizade, afastada do jugo social, perpassa as relações de dependência as quais Garcia pretende evitar para si. O distanciamento crítico do narrador em relação a Luís Garcia manifesta-se no fato de este deixar evidente as suas contradições em seu modo de agir e o juízo de valor implícito na descrição textual pode se desdobrar e caracterizar as personagens. Com isso, o narrador, ao marcar a posição e atitude de cada personagem (senhor e escravo), informa que mesmo as formas mais simples e ternas de relação estão postas na mira do sistema social. Nesse sentido, após aceitar o "obséquio" da moradia oferecida por Garcia, Raimundo convive com o seu "antigo senhor", partilha com ele as tarde no jardim da casa, em situação de dependência permeada de afeto. A vida doméstica de Garcia, então, revela uma face da personagem que o narrador aos poucos, e de maneira alternada, põe à baila do enredo.

"Entretanto, das duas afeições de Luís Garcia, Raimundo era apenas a segunda; a primeira era [...] filha" 41 , Lina, ou como a chamavam no âmbito doméstico e no colégio, Iaiá Garcia. Para ela a vida de Luís se abre em sorrisos e ternuras e, com ela, a casa da família Garcia torna-se festiva. A ligação íntima e afetiva de pai e filha afasta qualquer centelha de tristeza que pudesse haver na alma de Luís. Seus sentimentos, jamais postos em público, são revelados no seu comportamento e na própria face; seu "[...] rosto [...] acendia-se de um reflexo de juventude, que lhe dissipava as sombras acumuladas pelo tempo." 42 Do ponto de vista supostamente neutro, o narrador demonstra um elevado nível de felicidade e cumplicidade entre ambos, capaz de dissipar o perfil soturno, a face austera e indiferente de Garcia. Assim, quando sobe o morro aos finais semanas, porque

\footnotetext{
${ }^{39}$ Cf. FAORO, Raymundo. Op. cit.

${ }^{40}$ MACHADO DE ASSIS. Iaiá Garcia. Op.cit., p. 510, grifo nosso.

${ }^{41}$ Ibidem, p. 511.

${ }^{42}$ Ibidem, p. 512.
} 
estuda em um internato da cidade baixa, a garota, com a total atenção paterna, pode demonstrar seus novos conhecimentos.

\begin{abstract}
- Papai quer ouvir tocar piano? - disse [...] [Iaiá] um dia. - Olhe, é assim. E com os dedos na borda da mesa, executava um trecho musical sobre teclas ausentes. Luís Garcia sorriu, mas um véu lhe empanou os olhos. Iaiá não tinha piano! Era preciso dar-lhe um, ainda com sacrifício. Se ela aprendia no colégio, não era para tocar mais tarde em casa? Esse pensamento enraizou-selhe no cérebro e turbou o resto do dia. No dia seguinte, Luís Garcia encheu-se de valor, pegou da caderneta da Caixa Econômica e foi retirar o dinheiro preciso para comprar um piano. Eram da filha as poucas economias que ajuntava; o piano era para ela igualmente; não lhe diminuía a herança. ${ }^{43}$
\end{abstract}

Levando a cabo a descrição da relação familiar de Garcia, o narrador mostra como este homem conduzia a sua casa. "[...] Luís Garcia pagava-se do sacrifício contemplando a satisfação da filha." 44 Todos os resultados dos seus esforços e trabalho, suas economias, são dedicados à Iaiá, pois o seu amor paternal almeja satisfazer as vontades da garota. A felicidade da filha aparece no texto como preocupação primeira de Garcia, mesmo que isso represente um percalço financeiro à família, dada a condição social mediana na qual vivem. Esse aspecto ganha maior relevo no romance quando Iaiá Garcia compara o piano, "vasto móvel” "tão novo e lustroso", com o qual fora presenteada pelo pai, “[...] com os outros móveis da casa, modestos, usados, encardida a palhinha das cadeiras, roído do tempo e dos pés um velho tapete, contemporâneo do sofá". ${ }^{45}$ Os objetos contrastados inscrevem, definitivamente, a família em um estrato social médio, com algumas possibilidades e recursos, já que, com sacrifícios, Garcia paga pelo sonho da filha.

\footnotetext{
${ }^{43}$ Ibidem, p. 513

${ }^{44}$ Ibidem, p. 513.

${ }^{45}$ Ibidem, p. 513.

${ }^{46}$ Ibidem, p. 513.
}

Iaiá confiou um dia ao pai a idéia que tinha de ser mestra de piano. Luís Garcia sorria a esses planos da meninice, tão frágeis e fugidios como suas impressões. Também ele os tivera aos dez anos. Que lhe ficara dessas primeiras ambições? Um resíduo e nada mais. Mas assim como as aspirações daquele tempo o fizeram feliz, era justo não dissuadir a filha de uma ambição, aliás inocente e modesta. Oxalá não viesse a ter outras de mais alto vôo! Demais, que lhe poderia ele desejar, senão aquilo que a tornasse independente e lhe desse os meios de viver sem favor? Iaiá tinha por si a beleza e a instrução; podia não ser bastante para lhe dar casamento e família. Uma profissão honesta aparava os golpes possíveis da adversidade. Não se podia dizer que Iaiá tivesse talento musical: que importa? Para ensinar a gramática da arte, era suficiente conhecê-la. ${ }^{46}$ 
O cuidado paternal de Garcia que o narrador mostrara anteriormente, aparece reavaliado pela sua onisciência a respeito da consciência do funcionário público, porque, além de satisfazer o desejo de Iaiá, ele tem em mente a preocupação com o futuro da filha e articula uma maneira de garantir alguma segurança à garota caso ela não viesse a se casar. Na dinâmica social do século XIX, a preocupação de Garcia converge sobre a estabilidade social de Iaiá: sem dote, ela não conseguiria um marido, e, se solteira, não teria a quem recorrer na ausência paterna. Nessas condições, saber dedilhar o piano, a despeito da suposta falta de talento, representa para a menina um futuro como mestra desse instrumento musical e, também, uma das raras e incipientes alternativas femininas como meio de automanutenção. Por fim, essa ambição de Garcia converge com seu desejo em ver a filha livre das amarras da dependência social, da qual ele não se libertara.

Ao longo do primeiro capítulo, a aversão de Luís Garcia ao convívio social e ao sistema de favor pode sugerir um "[...] modelo [de comportamento] que implica embate interior e recusa de ceder quer ao império das emoções, quer à atração do interesse." ${ }^{, 47}$ No entanto, a validade dessa compreensão no enredo pode e deve ser confrontada com os comentários e intrusões do narrador, mas também com as atitudes contraditórias da personagem. Por meio desse conjunto, o narrador permite que as suas criaturas exponham seus sentimentos e angústia, mostrando-se ou em conflito com a realidade a sua volta, ou em contradição, quando, então, o narrador exibe sua ironia, dando a ver a adesão e reprodução a esta figura de linguagem.

Nesse sentido, o primeiro capítulo de Iaiá Garcia tem início com a leitura, por Luís Garcia, do bilhete de Valéria, contendo a mensagem: "Sr. Luís Garcia. Peço-lhe o favor de vir falar-me hoje, de uma a duas horas da tarde. Preciso de seus conselhos, e talvez de seus obséquios. Valéria". ${ }^{48} \mathrm{O}$ texto curto, mas objetivo, põe a narrativa em curso, porque, a partir dele, desencadeiam-se as relações sociais de favor entre os núcleos familiares ao longo da extensão do romance. O conteúdo dessa missiva representa um grande avanço na compreensão do lugar de cada personagem no romance, pois, o

\footnotetext{
${ }^{47}$ BOSI, Alfredo. Op. cit., p. 49.

${ }^{48}$ MACHADO DE ASSIS. Iaiá Garcia. Op.cit., p. 509.
} 
próprio narrador ao final do capítulo, afirma que "[...] a carta veio chamá-lo [Luís Garcia] ao drama que o livro pretende narrar."49

Sem esclarecer quem é Valéria, a narrativa passa da carta ao diálogo no qual Luís Garcia pede espontaneamente a Raimundo que confirme o pedido do encontro com a matriarca Gomes. Na sequência, o narrador se apropria do discurso, até o final do capítulo, a fim de demonstrar a aversão de Garcia às relações de cooptação e favor, bem como suas características interiores; e, se como afirma o narrador, o funcionário público usa de todo expediente para manter-se afastado das relações clientelistas, ao pedido da viúva Gomes ele se desprende da sua aversão pessoal. No momento em que recebe a carta com o apelo da senhora, sem demonstrar qualquer indício de hesitação ou constrangimento à solicitação de "conselhos" e "obséquios", ele age imediatamente como uma resposta positiva. Essa atitude positiva em relação ao pedido de um favor permite entrever a contradição na vida do homem livre, refratário ao mundo social. Algo em seu ânimo move-o em sentido oposto ao discurso narrativo que lhe atribui um perfil ascético e contrário ao sistema de favor. Afinal, a carta o chama para a possibilidade de prestar um obséquio e, com isso, inserindo-o dentro da estrutura social que tanto lhe repugna. $\mathrm{O}$ seu ato de prontidão e solicitude denuncia seu vínculo de dependência para com essa mulher. ${ }^{50}$

\footnotetext{
Valéria Gomes era viúva de um desembargador honorário, falecido cerca de dois anos [1864] [...] Não havia entre eles relações assíduas ou estreitas; mas a viúva e seu finado marido sempre o tiveram em boa conta e o tratavam com muito carinho. Defunto o desembargador, Valéria recorrera duas ou três vezes aos serviços de Luís Garcia; contudo, era a primeira vez que o fazia com tamanha solenidade. ${ }^{51}$
}

A descrição da relação das famílias Gomes e Garcia denota o status de Valéria como uma mulher de posição social privilegiada em relação a Luís, por ser ela viúva de um "desembargador honorário". O título do seu falecido marido coloca-a no constelado mundo das famílias privilegiadas que unem as posses pessoais a uma função pública de notoriedade. A matriarca Gomes tem uma posição de destaque social, ainda que não seja membro da nobreza, mas que lhe dá a distinção de classe. Proprietária, vivendo de aluguel, a sua insígnia do status familiar ganha um forte contorno na narrativa por meio

\footnotetext{
${ }^{49}$ Ibidem, p. 514.

${ }^{50}$ Cf. SCHWARZ, Roberto. Op. cit.

${ }^{51}$ MACHADO DE ASSIS. Iaiá Garcia. Op. cit., p. 514.
} 
da declaração, a Luís Garcia, da motivação para enviar o filho às frentes de batalha da Guerra do Paraguai:

- Jorge está formado - disse ela -, mas não tem queda para a profissão de advogado nem para a de juiz. Goza por enquanto a vida; mas os dias passam, e a ociosidade faz-se natureza com o tempo. Eu quisera dar-lhe um nome ilustre. Se for para a guerra, poderá voltar coronel, tomar gosto às armas, segui-las e honrar assim o nome de seu pai. ${ }^{52}$

Valéria recorre ao obséquio de Garcia para convencer Jorge a se alistar na Guerra do Paraguai como militar. A ida do rapaz às frentes de batalha, para ela, surge como uma solução eficaz e gloriosa de dois problemas domésticos que poderiam afetar o estofo social familiar: a união afetiva de seu filho com a agregada da casa (Estela) e a vida de "casquilho" de Jorge, que não coroava com nenhum louro o sobrenome paterno. A Guerra do Paraguai, então, serve à matriarca como fronteira à aproximação entre a agregada e o filho, e como garantia aos Gomes de uma patente militar, “[...] um posto de alferes ou tenente; [...] major ou coronel"53; honraria de prestígio do Segundo Reinado, envolto em sua “[...] imensa rede de títulos, comendas e patentes [que] doura a sociedade, revelando debaixo dos embelecos, rigoroso mecanismo de coesão e forças",54 usado para a automanutenção do poder imperial.

Consonante com essa dinâmica social, quando recorre aos obséquios de Luís Garcia, a matriarca Gomes apenas vale-se da relação, de longa data, gerada pela disparidade social entre ambas as famílias com a finalidade de angariar apoio na execução de seu capricho pessoal, tendo em vista a manutenção de seu status social. Nesse contexto, o início do segundo capítulo retoma o pedido da viúva, escrito em tom de ajuda e desamparo na carta a Luís Garcia. A relação entre ambos torna-se evidente, porque apesar da "hora aprazada" ser incômoda para Garcia, afinal seus "hábitos de trabalho mal sofriam interrupção" ${ }^{, 55}$, ele comparece ao encontro. Pertencente a camadas médias do século XIX escravocrata, o seu comportamento regrado, refratário e arredio às circunstâncias sociais, acaba não sendo suficiente para afastá-lo das relações de dependência; situação que o alinha ao plano histórico no qual a transição da "velha

\footnotetext{
52 Ibidem, p. 515.

${ }^{53}$ Ibidem, p. 515.

${ }^{54}$ Cf. FAORO, Raymundo. Op. cit., p. 29.

${ }^{55}$ MACHADO DE ASSIS. Iaiá Garcia. Op. cit., p. 514.
} 
sociedade de estamentos [...] [para a] sociedade de classes" ${ }^{\circledR 6}$ foi um processo lento que não prescindiu dos "instrumentos e do aparelho estamental.",57

Essas relações sociais da realidade brasileira do século XIX, que margeiam a trama narrativa, além de servirem ao autor como índice de realismo ao romance, são analisadas em relação à estética literária romântica e realista, a fim de conferir maior verossimilhança às personagens. A sua visão sobre as relações da sociedade brasileira oitocentista orienta as escolhas e atitudes das suas criações, eliminando os excessos estéticos "da cor local", do "puro domínio da imaginação" 58 , como também, a tentativa de persuasão realista. ${ }^{59}$ Machado de Assis considera a importância da psicologia das suas criações, seus "nervos, paixões, remorsos e moral"60, trabalhadas em meio à canhestra sociedade que adapta o ideário burguês ao sistema de favor e cooptação ${ }^{61}$. Sua proposta, então, é analisar a sociedade e os motivos que levariam a incipiente classe média brasileira ao conformismo e à resignação diante do sistema clientelista.

Assim é que podemos, através da sua obra ficcional (a qual, sendo obra de criação, melhor exprime as reações íntimas suscitadas pelo ambiente na sensibilidade do escritor), as modificações operadas na mentalidade reinante em seu tempo, paralelamente ao desenvolvimento econômico, político e social do País. ${ }^{62}$

Dessa maneira, o narrador demonstra que Luís Garcia aceita os préstimos de Valéria, aderindo ao sistema de dependência social, mesmo já tendo uma possibilidade mínima de automanutenção. O poder e prestígio dos Gomes são elementos de forte preponderância da vida do funcionário público. A sua aderência ao jugo do poder da matriarca evidencia seu caráter passivo o qual o narrador pretende revelar como reflexo de uma incipiente classe média conivente com o sistema de cooptação e favor. Assim,

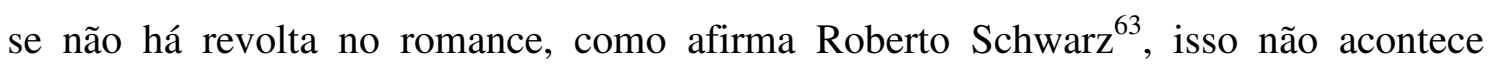
porque o narrador compactue com o sistema clientelista brasileiro; pelo contrário, ele denuncia a mediocridade da sociedade estamental, na qual a camada média prefere se

\footnotetext{
${ }^{56}$ FAORO, Raymundo. Op. cit., p. 5.

${ }^{57}$ Ibidem, p. 7.

${ }^{58}$ Cf. MACHADO DE ASSIS. Instinto de nacionalidade. In: Obra completa: crítica Literária. Organização Henrique de Campos. São Paulo: Editora Mérito, 1959, p. 129-149.

${ }^{59}$ Cf. Idem. O primo Basílio, por Eça de Queirós. Op. cit., 1959, p. 154-179.

${ }^{60}$ Ibidem, passim.

${ }^{61}$ Cf. SCHWARZ, Roberto. Op. cit.

${ }^{62}$ PEREIRA, Astrojildo. Romancista do Segundo Reinado. In: apontamento avulsos. Rio de Janeiro: Livraria São José, [1959]. p. 22. Machado de Assis: ensaios e

${ }^{63}$ Cf. SCHWARZ, Roberto. Op. cit.
} 
anular socialmente a não ter os seus interesses atendidos; conformismo figurativo do comportamento das personagens, que o narrador, na sua troca sucessiva de pontos de vista, passa a criticar.

Ao analisar o primeiro capítulo de Iaiá Garcia, pode-se observar que a escolha da abordagem narrativa no romance tende, parcialmente, a apoiar-se no discurso do narrador onisciente neutro. Porém a distância alcançada pelo narrador das personagens não permanece contínua e segura ao longo do romance, como se o escritor tateasse nesse recurso. $\mathrm{O}$ narrador, então, aparece como uma figura ambígua, porque "[...] se envolve num casulo de reticências e interrogações, para cultivar a arte dos graciosos desmentidos." ${ }^{64}$ Suas discretas intromissões confundem-se em meio à descrição neutra, que, por vezes, chocam-se com a ação da personagem, exercendo, com isso, ora um mecanismo de eleição, ora um mecanismo de rejeição desta. "Para o leitor de Machado de Assis, o problema está em avaliar o grau de distanciamento que o narrador crítico (embora, na aparência, concessivo) guarda em relação a cada personagem e a cada situação.",65

$\mathrm{Na}$ definição de Luís Garcia, isso significa dizer que o narrador não tem muita empatia pela personagem, porque, em linhas gerais, ele vale-se da condição social mediana de Garcia, enfatizando a sua aversão pelo sistema social de dependência, a fim de criar-lhe uma "máscara imóvel" só aparentemente virtuosa e resistente ao clientelismo. Ao final, esse traço ascético de personalidade, anteposto no enredo, quando aproximado do obséquio prestado à Valéria, que no futuro lhe garante o dote da filha, desmistifica o caráter severo da personagem. O narrador, então, assume um discreto ponto de vista irônico em relação ao comportamento de Garcia. Crítico, o narrador subverte a imagem da personagem como um sujeito distanciado dos entraves do sistema a sua volta.

Dessa maneira, a narrativa adota um pretenso tom "enluvado". Escamoteando-se entre a onisciência neutra e intrusiva, o narrador tende a sumarizar a história como forma de acesso à psicologia das personagens, no entanto, fingindo distanciamento, ao recuar a sua descrição e permitir à personagem se mostrar de dentro para fora, da posição ativa, ele evidencia as escolhas e desejos das suas criaturas para, em seguida, expô-las em

${ }^{64}$ MEYER, Augusto. O romance machadiano: o homem subterrâneo. In: BOSI, Alfredo (Org.) et al. Machado de Assis. São Paulo: Ática, 1982. p. 357. (Coleção Escritores Brasileiros Antologia e Estudos).

${ }^{65}$ BOSI, Alfredo. Op. cit., p. 49. 
contradição. Por meio desse intrincado mecanismo de alternância de foco, torna-se possível o alargamento da expressão psicológica das personagens, problematizando-as na estrutura do romance. Essa composição que, apesar de ainda não representar tecnicamente “[...] o narrador que personifica a multiplicidade do devir ideológico [...] ${ }^{\prime 66}$ dos romances machadianos posteriores a Iaiá Garcia, já demonstra uma tentativa de desmistificar a verdade absoluta do foco narrativo unívoco.

Machado de Assis, então, também não se vincula, como se sabe, ao realismo naturalista. Neste, a prosa de ficção é tomada como uma teoria a ser demonstrada por meio da descrição estanque, em que "um fato observado fará eclodir a idéia da experiência que deve instituir, do romance que deve escrever, para chegar ao conhecimento completo de uma verdade." ${ }^{, 67}$ Para o escritor, fazia-se necessário rever a tradição, as "doutrinas" do passado e do presente, o legado romântico e o postulado realista, aproveitando desses dois movimentos estéticos os elementos que pudessem fortalecer a arte e a manifestação da imaginação literária.

Não peço, decerto, os estafados retratos do romantismo decadente; pelo contrário, alguma coisa há no realismo que pode ser colhido em proveito da imaginação e da arte. Mas sair de um excesso para cair no outro, não é regenerar nada: é trocar o agente da corrupção. ${ }^{68}$

Como já havia anunciado na advertência de Ressurreição $o^{69}$, seu primeiro romance, Machado de Assis está em busca de uma forma literária que consiga abarcar "o contraste de dois caracteres" em uma mesma personagem e desta em relação à outra. Seu objetivo consiste em altercar as duas naturezas humanas. Ele "[...] encena o drama dos eventos internos, privilegiando as reações passionais e os conflitos emocionais dos personagens nas diversas situações dramáticas. Em seguida, porque ele concebe a ficção narrativa como encenação do drama inerente no horizonte móvel do tempo. ${ }^{70}$ Nesse procedimento, "desejo e interesse" com suas aspirações e paixões contraditórias em meio ao peso dos valores sociais.

\footnotetext{
66 SOUZA, Ronaldes de Melo e. O romance tragicômico de Machado de Assis. Rio de Janeiro: EdUERJ, 2006. p. 21.

${ }^{67}$ ZOLA, Emile. O romance experimental e o naturalismo no teatro. Tradução Italo Caroni; Célia Berrettini. 2. ed. São Paulo: Perspectiva, 1982. p. 35.

${ }^{68}$ MACHADO DE ASSIS. O primo Basílio, por Eça de Queirós. Op. cit., 1959.

${ }^{69}$ Idem, Ressurreição. Op. cit., 2008, p. 235-236.

${ }^{70}$ SOUZA, Ronaldes de Melo e. Op. cit., p. 52.

${ }^{71}$ BOSI, Alfredo. Op. cit., p. 21.
} 


\title{
CAPÍtULlO II
}

\section{ESTELA: A AUSTERIDADE EM DEFESA DA DIGNIDADE PESSOAL}

Em Iaiá Garcia, a compreensão do romance como elemento atravessado pela ambiguidade narrativa se estiliza também no binômio amor-casamento. Calcado na proposição de que na arte a trama lógica das paixões fomenta a estrutura do enredo romanesco, pois, caso contrário, ele apenas estaria associado a elementos acessórios à narrativa, ${ }^{72}$ Machado de Assis volta-se para a problematização das relações afetivas em suas diversas variações no seio social como fonte temática da literatura. Nesse sentido, a relação entre amor e casamento surge na trama narrativa como elemento de relevância por refletir sobre os paradoxos da realidade brasileira de meados do século XIX, transpondo para a obra de ficção a problemática de uma sociedade estratificada.

\begin{abstract}
Em suas diversas modulações - noivados, rompimentos, adultérios, viuvez o casamento é, como a maternidade, aquela "complicação no natural com o social" que, de Ressurreição (1872) a Memorial de Aires (1908), preocupa o narrador, define os personagens e determina a ação. São, quase sempre, as incursões do amor na placidez da família que lhe permitem desnudar, na análise dos conflitos suscitados, tanto as conveniências da moral tradicional do patriarcalismo, quanto os interesses da nova moral burguesa relativa ao amor e ao casamento, que, gradativamente, ao longo do século XIX, impuseram-se na sociedade brasileira. ${ }^{73}$
\end{abstract}

Em sua narrativa, Machado de Assis, problematiza as relações afetivas e matrimoniais, atrelando-as ao poder patrimonial, revelando, com isso, as nuances de comportamento de suas personagens. Esse duplo componente serve-lhe de base ao desdobrar, na intriga do seu texto, conflitos socioafetivos relativos aos oitocentos. Nessa mescla de imaginação e realidade, o escritor acompanha os intricados valores socioculturais presentes na escolha matrimonial, desnudando em Iaiá Garcia a gradativa mudança temporal de comportamentos e de mentalidade, em suas principais figuras femininas: Estela e Iaiá. Peças determinantes do enredo, essas personagens divergem entre si quanto à natureza dos valores pessoais, indicando no romance uma divisão entre passado e presente das relações socioafetivas.

\footnotetext{
${ }^{72}$ Cf. MACHADO DE ASSIS. O primo Basílio, por Eça de Queirós. Op. cit., 1959.

${ }^{73}$ MURICY, Katia. A razão cética: Machado de Assis e as questões do seu tempo. São Paulo: Companhia Das Letras, 1988. p. 13.
} 
Temporalmente dividido pela Guerra do Paraguai, a primeira parte do romance detémse no núcleo de relações sociais no qual Estela aparece como figura central. Agregada da casa de Valéria Gomes, ela passa os dias com a viúva, servindo-lhe de companhia e ouvindo-lhe os lamentos pessoais. O convívio entre ambas transcorre tranquilo, sem qualquer tipo de distúrbio, até o momento em que Jorge Gomes, após bacharelar-se em direito, regressa de São Paulo. A princípio os dias do rapaz são dedicados à vida mundana na rua do Ouvidor, mas, com o passar do tempo a presença da moça lhe conquista o interesse. Desde uma sessão de leitura de alguma literatura para Valéria e Estela, Jorge passa rapidamente a desejar a agregada de sua casa, sem que esta lhe retribua com qualquer sinal. Valéria, vendo o filho levar uma vida ociosa, sem um destino condizente com a reputação social da família, articula casá-lo com alguma jovem de mesma posição, mas acaba vendo seus planos beirarem o fracasso quando percebe os sentimentos do filho por Estela.

No terceiro capítulo do livro o narrador chega ao centro nevrálgico da trama, por meio de flashback, ao descrever Estela e inseri-la no contexto do drama doméstico que desencadeia os conflitos do romance. Ela é uma jovem de origem humilde que passa a viver na casa da família Gomes aos dezesseis anos de idade, após terminar seus estudos. O acolhimento pelos Gomes tem como motivo a admiração de Valéria pela jovem, no entanto, a condição de agregada já havia sido estabelecida a priori pela dependência social de seu pai, Sr. Antunes, em relação ao desembargador Gomes, como convinha ao costume da sociedade patriarcal.

\footnotetext{
Morta a mulher [de Antunes], [ele] alcançou do desembargador um enxoval completo para fazer entrar a filha num colégio, visto que até então nada aprendera, e já agora não podia deixá-la sozinha em casa. O desembargador dera o enxoval; algumas vezes pagou o ensino; as visitas amiudaram-se; a criança, que era bonita e boa, entrou manso e manso no coração de Valéria que a recebeu em casa, no dia em que a pequena concluiu os estudos. ${ }^{74}$
}

Enquanto vivia apenas sob a tutela de seu pai, Estela levava uma vida simples, sem condição financeira suficientemente boa para ter uma educação formal - privilégio para raras jovens da sua época. A infância da filha de Antunes se resumia ao lar, em torno da mãe, como era comum à tradicional educação feminina patriarcal, na qual o trabalho doméstico representava as atribuições das jovens, pois “[...] comprimida pela estrutura

\footnotetext{
${ }^{74}$ MACHADO DE ASSIS. Iaiá Garcia. Op. cit., 2008, p. 522.
} 
funcional da residência, [a mulher] era obrigada a dispensar [...] ocupações supérfluas e ocupar o tempo ocioso nos trabalhos caseiros."75 Já a educação voltada ao aprendizado “[...] das primeiras letras e das gramáticas portuguesa e francesa - 'os trabalhos de agulha e tesoura', música, canto, dança"76 nos primórdios da formação da jovem de classe média, fazem parte da vida de Estela somente após a morte de sua mãe, quando ela recebe o "enxoval” do patriarca Gomes.

A dependência da família Antunes em relação aos Gomes fica explícita na passagem em questão, pois além de dar o enxoval de Estela, o desembargador eventualmente paga pelo ensino da filha de um empregado da família. Ao tratar da educação da moça, o narrador joga luz sobre a diferença social entre as famílias, apontando a validade do poder patriarcal no seio dessa relação. A regularidade do estatuto do homem livre e pobre, subordinado e dependente do poder do homem de posses, evidência de que ambas as famílias vivem sob os valores estamentais de tradição e poder. Assim, Antunes aceita de bom grado o favor prestado pelo seu protetor, tendo em vista a melhoria da sua condição de vida e a possibilidade de dar à filha alguma educação formal, a mesma que algumas jovens, de melhor posição social, começam a receber em meados dos oitocentos. Contudo, se na companhia da mãe, na sua infância, Estela "nada aprendera", do colégio o narrador não diz qual foi a sua aprendizagem, ficando para a descrição da sua compleição física o desprendimento da sua psicologia.

Pálida era, mas sem nenhum tom de melancolia ascética. Tinha os olhos grandes, escuros, com uma expressão de virilidade moral, que dava à beleza de Estela o principal característico. Uma por uma, as feições da moça eram graciosas e delicadas, mas a impressão que deixava o todo estava longe da meiguice natural do sexo. Usualmente, trazia roupas pretas, cor que preferia a todas as outras. $\mathrm{Nu}$ de enfeites, o vestido punha-lhe em relevo o talhe esbelto, elevado e flexível. Nem usava nunca trazê-lo de outro modo, sem embargo de algum dixe ou renda com que a viúva a presenteava de quando em quando; rejeitava de si toda a sorte de ornatos; nem folhos, nem brincos, nem anéis. Ao primeiro aspecto dissera-se um Diógenes feminino, cuja capa, através das roturas, deixava entrever a vaidade da beleza que quer afirmar-se tal qual é, sem nenhum outro artifício. Mas, conhecido o caráter da moça, eram dois os motivos - um sentimento natural de simplicidade, e, mais ainda, a consideração de que os meios do pai não davam para custosos atavios, e assim não lhe convinha afeiçoar-se ao luxo. ${ }^{77}$

\footnotetext{
${ }^{75}$ COSTA, Jurandir Freire. Ordem médica norma familiar. 5. ed. Rio de Janeiro: Graal, 2004. p. 83.

${ }^{76}$ RENAULT, Delso. Rio de Janeiro: a vida da cidade refletida nos jornais (1850-1870). São Paulo: Civilização Brasileira, 1978. p. 105.

${ }^{77}$ MACHADO DE ASSIS. Iaiá Garcia. Op.cit., 2008, p. 524, grifo nosso.
} 
O primeiro traço descrito de Estela, sua palidez, busca inspiração na figura da mulher marmórea, perfil estabelecido e largamente difundido pelo romantismo. Porém, sem restringi-la à categoria do tipo, a composição físico-moral desvenda-lhe integralmente aos olhos do leitor. Como faz na descrição de Luís Garcia, o narrador logo trata de amenizar esse sinal estético da palidez, dizendo que o semblante de prostração ascética, da religiosa de comportamento devoto e submisso, não fazia parte da imagem vista em Estela. A referência à usual imagem da mulher "pálida" do movimento romântico surge como um indício, uma pista deixada como indicativo da filha de Antunes.

Com temperamento mais denso, como pretende Machado de Assis para as suas personagens, a personificação da jovem não se reduz à referência imediata do estereótipo da musa romântica. A palidez de Estela, na qual contrastam seus "grandes olhos escuros" e suas roupas negras, ressalta "a expressão de virilidade moral" que transparece em seu olhar. A oposição entre claro e escuro, presença e ausência, reforça e metaforiza a caracterização de uma figura feminina de forte princípio pessoal. Por meio da simplicidade em se vestir, sem enfeites e nem joias, a roupa negra lhe garante a beleza natural do corpo e ressalta sua força moral, pois, despida de qualquer adorno, Estela se mostra fiel a sua origem humilde.

Nesse sentido, opondo-se à "meiguice natural do sexo" que se entrega ao gosto mundano por bordados, joias e laçarotes, índices de distinção da mulher burguesa, Estela veste negro, a cor do luto, da ausência de alegria. Suas roupas metaforizam, como propõe o narrador, a capa de um Diógenes ${ }^{78}$ feminino, insígnia de resistência e valor pessoal. Preocupada em evitar o seu desprestígio, Estela afirma a sua posição mediana na estrutura social e revela o seu desinteresse em ocupar uma posição superior a sua origem. Com isso, o narrador ironiza o imaginário patriarcal da mulher como um ser passivo e fútil, porque, contrariando o recorrente discurso misógino da época, presente

\footnotetext{
78 "Filósofo grego de Siracusa, Diógenes viveu nos séculos V e IV a.C. O seu sistema filosófico consistia no desprezo das riquezas materiais e das convenções sociais, e no apreço pelas leis da Natureza; andava descalço, dormia debaixo dos pórticos embrulhado na sua única e rota capa, e tinha por domicílio habitual um tonel." ROMANCES EM HIPERTEXTO: Iaiá Garcia: Banco de dados preparado por Marta de Senna. In: FUNDAÇÃO CASA DE RUI BARBOSA. Machado de Assis.net: no ar desde 2007. Disponível em: <http://www.machadodeassis.net/hiperTx_romances/obras/iaiagarcia.htm>. Acesso em: 9 Jan. 2011.
} 
mesmo na prática jurídica do século XIX, ${ }^{79}$ Estela é descrita como uma mulher imbuída de valores pessoais distintos do estereótipo da mulher ingênua e fragilizada.

A filha de Antunes reconhece e assume a sua posição desprivilegiada na esfera social, evidenciando sua altivez em uma das primeiras cenas do romance, na qual ela é convidada a participar do jantar oferecido a "gente de fora" por Valéria Gomes. A ocasião, como mandaria o figurino da época, pede muita pompa, afinal a matriarca Gomes está recebendo visitas, e sua posição social exige mais polidez e elegância. Para Jorge Gomes, dândi da rua do Ouvidor, sem muitas preocupações com valores sociais ostentados por sua mãe, o momento serve como passatempo no qual ele pode provocar Estela e descobrir um suposto temperamento encoberto pela seriedade e sisudez da jovem diante da plateia de convidados.

No jantar, Jorge a questiona sobre o motivo pelo qual ela não usa os brincos dados por Valéria e tem como resposta: "Os presentes mais queridos guardam-se, respondeu ela olhando para a viúva." ${ }^{80} \mathrm{O}$ argumento de Estela sai em tom delicado e polido, sem insinuar o seu verdadeiro motivo, seu orgulho moral. Enquanto se dirige verbalmente ao rapaz, ela busca, com o olhar, a expressão do rosto da viúva. No seu olhar fugidio, ela denuncia a sua preocupação com a reação da sua protetora, que lhe dera o presente; não usá-lo representa, então, uma negativa de sua submissão à matriarca e, também, a expressão do orgulho pessoal. Paradoxalmente, Estela se mostra preocupada com a reação da amiga, a quem deve favores, ao mesmo tempo em que deseja ressaltar um princípio de superioridade íntima. Evitando usar a joia, índice de dependência e submissão, ela ostenta e afirma sua origem desprivilegiada, de uma mulher sem posses.

Analisando esse orgulho moral da personalidade de Estela, Alfredo Bosi, em Machado de Assis: o enigma do olhar, supõe ser mais coerente reconhecer na "virilidade moral" da personagem um perfil de comportamento que não estaria “[...] à frente das coordenadas brasileiras dos meados do século XIX". ${ }^{81}$ Estela teria um comportamento assimétrico ao da mulher burguesa às voltas com as regras sociais que pediam da mulher uma postura afável e receptiva na sala de estar, refletindo um pretenso ar de

\footnotetext{
${ }^{79}$ Cf. DUBY, Georges; PERROT, Michelle (Dir.). Histoire des femmes en Occident : le XIX ${ }^{\mathrm{e}}$ siècle. Paris : Perrin, 2002. v. IV, 765 p.

${ }^{80}$ MACHADO DE ASSIS. Iaiá Garcia. Op. cit., 2008, p. 524

${ }^{81}$ BOSI, Alfredo. Op. cit., p. 49.
} 
harmonia doméstica. Para o crítico, a conduta de Estela assemelha-se ao "[...] valor de nobreza, caro a uma vertente central da Ilustração sete-oitocentista [...] a qual começou a estender para o Terceiro Estado certas qualidades milenarmente atribuídas à aristocracia como o sentimento de honra pessoal e a dignidade do sujeito." ${ }^{~} 8$

Por outro lado, o caráter da jovem aponta para uma possível releitura de Stendhal por Machado de Assis. Na teoria do escritor francês sobre o orgulho feminino, em Do amor, durante toda a vida as mulheres estariam em contato, como ouvintes passivas, com narrativas de aventuras masculinas nas quais a temática sempre ressalta grandes desafios, empreitadas heroicas, bem recebidas pelo clamor público. Os feitos masculinos, sempre envoltos em uma aura de prestígio, tratam “[...] de assuntos pretensamente importantes, de grandes ganhos de dinheiro, de sucesso na guerra, de pessoas mortas em duelos, de vinganças atrozes ou admiráveis, etc" ${ }^{~} 83$ Organizados em um clã de atmosfera guerreira, no qual os seus atos são engrandecidos por meio do discurso uníssono masculino, os homens podem gozar de uma fama pública sobre seus atos "pretensamente" tidos por grandiosos, enaltecendo uma suposta supremacia e superioridade social do brio masculino. Nesse mundo fechado, circunscrito em uma aura autossustentada pelo domínio patriarcal, as mulheres se veem em posição de menosprezo pela restrição de seu campo de ação reduzido à vida doméstica.

Assim, "aquelas que, dentre elas, possuem uma alma altiva sentem que não podem alcançar esses objetivos, não têm condições de desenvolver um orgulho notável pela importância das coisas que apoia." ${ }^{\circledR 4}$ Mas isso para elas não significa abdicar do desejo de ver-se também como um agente ativo e honrado na sociedade. O contato com esse discurso provoca-lhes os sentimentos e desejos de reconhecimento público e a altivez de caráter, quando ainda "[...] veem o último dos homens considerar-se mais do que elas. Percebem que só podem demonstrar orgulho por pequenas coisas, ou pelo menos por coisas que só têm importância pelo sentimento, um terço das quais não pode ser julgado. $\$ 85$

\footnotetext{
${ }^{82}$ Ibidem, p. 49, grifo do autor.

${ }^{83}$ STENDHAL. Do amor. Tradução Roberto Leal Pereira. 2. ed. São Paulo: Martins Fontes, 1999. p. 63, grifo nosso.

${ }^{84}$ Ibidem, p. 63.

${ }^{85}$ Ibidem, p. 63-64.
} 
Essas mulheres, quando desprezadas pela autovalorização da figura masculina, compreendem a contradição entre "a baixeza do seu destino e a altivez de sua alma." 86 Porém, ao invés de sucumbirem ao jugo social, ao ver-se em desvantagem em relação ao homem, reforçam e elevam o seu orgulho, tornando-se austeras. Cientes do lugar inferior que a sociedade lhes reserva, o que contrasta com a sua dignidade pessoal, elas se expressam por meio do arroubo pessoal, manifestando à sociedade seus princípios íntimos de soberania. Nesse sentido, Stendhal ironiza a visão romântica do amor como circunstância atribuída ao ato guerreiro de bravura e heroísmo, porque, enquanto construção discursiva do regime patriarcal, ele apenas representa a vaidade masculina face o desprestígio da figura feminina. Assim, "certas mulheres", potencializando o seu sentimento de honra, elegem e fazem resplandecer o seu orgulho pessoal por meio de uma postura social fria e austera, minando a visão do amor cultuado na disparidade social de gênero.

Voltando-se ao passado medieval, Stendhal lança mão dos valores de honra pessoal a fim de revê-los sob a compreensão sociocultural. Na leitura dos valores corteses, a antiga "senhora" não corresponde aos anseios do homem investido da grandeza de um feito épico como testemunho do seu amor. Ciosa da sua dignidade pessoal, essa mulher reconhece e ostenta em si a dignidade de não ceder a uma relação concebida pelo discurso patriarcal, que lhe relega uma posição social inferior. Nessa análise do orgulho feminino - bem como em todos os outros tópicos abordados em Do amor - Stendhal pretende desenvolver "[...] um sistema acerca da influência dos governos sobre as paixões [...]"87 e, dessa maneira, verificar os conflitos suscitados por meio do peso social sobre os sentimentos, revendo a afetividade no decurso histórico das relações sociais no ocidente.

Já Machado de Assis, por meio da observação da particularidade da vida brasileira faz convergir em Estela a aura "magnificente" ostentada pelo caráter feminino de "algumas mulheres", alçado na teoria stendhaliana, quando a moça assume seu orgulho, e tenta impor-se socialmente. Ao recusar usar os brincos dados por Valéria, ela está claramente lutando para mostrar-se acima do clientelismo ostentado pelos Gomes. Contudo, independentemente das suas convicções pessoais, ela se liga ao poder de Valéria. Na

\footnotetext{
${ }^{86}$ Ibidem, p. 64.

${ }^{87}$ Ibidem, p. 66.
} 
cena do jantar na casa dos Gomes, a viúva intervém no diálogo entre Estela e Jorge de maneira pontual e objetiva. Aperta o queixo de Estela entre os dedos, em um ato de duplo sentido, pois, por um lado, subentende-se a relação de proximidade entre elas. Por outro, o gesto da matriarca indica o poder despótico da viúva. Valéria se refere à fala da moça como sendo um ato de "Poeta!", para, em seguida, concluir: "- Você não precisa de brincos para ser bonita, mas vá pô-los, que lhe ficam bem.." ${ }^{88}$ Outra vez a narrativa mostra uma ambiguidade de sentido, porque a fala da matriarca pode tanto indicar a maneira poética como a jovem se reporta em público, como também apenas um estado de dissimulação de Valéria que, primeiro recorre ao elogio, para em seguida emitir a ordem.

Foi a primeira e última vez que Estela os pôs. A intenção era patente demais para não ser notada, e Jorge não esqueceu nem a resposta da moça nem o constrangimento com que obedeceu. Não podia supor-lhe ingratidão, porque via a afeição com que Estela tratava a mãe. ${ }^{89}$

Ambas encenam no espaço doméstico seus papéis de proprietária e agregada, no qual a matriarca exerce o poder de coerção sobre a outra, inferiorizada pela condição de dependente. Contra-regra desse jogo social, Valéria não titubeia ao eleger e determinar a condução das relações familiares, sem jamais abrir mão de seu mando. Nesse sistema, Estela apenas figura como acompanhante da rica viúva, que lhe quer bem e lhe proporciona proteção social. Mas a estima entrelaçada de dependência não reconforta $o$ caráter da jovem. Estela não pretende ver-se subjugada e humilhada. Apesar do ultraje da cena, a jovem não perde o brio e nunca mais volta a colocar os brincos, ostentando um comportamento orgulhoso e ambíguo, porque ela faz parte desse ambiente clientelista.

O molde da "virilidade moral" de Estela ou, em outras palavras, o seu orgulho resume a grosso modo, a sua dificuldade de agir no âmbito social com igualdade de força em relação à família Gomes. Alinhada na esfera de um sistema estratificado, em uma época em que a força de trabalho era escrava, e a mulher burguesa tinha participação apenas na estrutura doméstica, ela não possui muitas alternativas para se automanter. Mulher, de família pobre, sem fonte de renda assalariada, sua vida está vinculada à dependência aos Gomes. Por isso, o seu princípio de "nobreza", a sua "elevação de sentimentos" gera

\footnotetext{
${ }^{88}$ MACHADO DE ASSIS. Iaiá Garcia. Op. cit., 2008, p. 524, grifo nosso.

${ }^{89}$ Ibidem, p. 524, grifo nosso.
} 
o seu conflito interno ao se deparar com a maneira espúria das relações sociais dominantes.

O paternalismo, ordem dominante no espaço da sociedade brasileira em meados do século XIX, materializa-se no enredo de Iaiá Garcia justamente por expor esse conflito em personagens como Estela e Luís Garcia. Ambos querem distância do sistema de cooptação, mas sendo ele a regra e a prática da sociedade, atingindo todas as camadas sociais, do escravo ao rico proprietário, Estela e Garcia ainda se sujeitam a ele como meio de automanutenção, dando assim continuidade ao ciclo da dependência. Logo, a forma de dominação vigente pela estrutura paternalista, ao menos na primeira parte do romance, está baseada na dependência do "homem livre" em relação ao homem de posses. Vivenciado desde o Brasil colônia, esse sistema social perpetuou-se ao longo da história, refletindo a precariedade da sociedade brasileira no que tange à falta de oportunidade de trabalho para o "homem livre na sociedade escravocrata". 90

Vale ressaltar que a expressão austera de Estela aponta para a maior simpatia do narrador por esta personagem quando comparada a Luís Garcia. Este, ao ser descrito como homem ascético no primeiro capítulo do romance, tem seu comportamento socialmente esquivo, mas interesseiro, debochado pelo narrador; essa compreensão é reforçada, quase no final do romance, no comentário de Estela à Iaiá: "Teu pai não tinha os mesmos sentimentos que eu; era mais tímido que orgulhoso."91 Altiva, Estela julga a postura refratária à sociedade de Garcia como resultado de uma personalidade tímida. Ao contrário dela, o marido não ostentava o orgulho de ter princípios pessoais e, dessa maneira, Luís Garcia é motivado por interesses sociais bem definidos, escondidos atrás da sua máscara avessa ao sistema de dependência. Dessa aproximação de personalidades, Estela, orgulhosamente, ratifica sua superioridade moral por meio do rigor de seu comportamento.

Na construção de Estela e Luís Garcia, o narrador projeta no romance dois caracteres que podem ser trabalhados em paralelo. Em linhas gerais, a expressão de sobriedade desenvolvida em ambas as personagens permite uma aproximação que lhes expande e reforça a personalidade. Ao descrever o temperamento de Garcia, por meio de uma

\footnotetext{
${ }^{90}$ Cf. FRANCO, Maria Sylvia de Carvalho. Op. cit.

${ }^{91}$ MACHADO DE ASSIS. Iaiá Garcia. Op. cit., 2008, p. 617.
} 
moral titubeante e reticente, e Estela pela valorização da austeridade com a qual age socialmente, o narrador, trabalhando por meio de contrastes, alarga e reforça em um e outro os propósitos pessoais. Enquanto Luís leva uma vida mediana, atravessada pelo interesse, Estela luta para se manter coerente a sua moral anticlientelista, reagindo com severidade. Com isso, o paralelo entre o futuro casal faz resplandecer a ambiguidade do comportamento de Garcia e o "estoicismo" de Estela. ${ }^{92}$

Entre Estela e Luís Garcia, a opção do narrador por criticar o caráter do viúvo ganha força de expressão, porque, ao contrário de Garcia que apenas mascara seu interesse em melhorar as condições de vida de sua filha, Estela, a despeito de também valer-se das vantagens de ser amiga de Valéria, tem um sentimento forte de dignidade. Sua honra pessoal representa, para ela, um sentimento moralmente superior à cooptação social, fazendo-a agir de maneira severa. Essa altivez da moça ganha mais relevo quando o narrador afirma que ela "era o vivo contraste do pai". 93

O sr. Antunes, que não era de extremas filosofias, tinha a convicção de que debaixo do sol, nem tudo são vaidades, como quer o Eclesiastes, nem tudo perfeições, como opina o dr. Pangloss; entendia que há larga ponderação de males e bens, e que a arte de viver consiste em tirar o maior bem do maior mal. ${ }^{94}$

Contrariamente à filha, Sr. Antunes assume um posicionamento social desprovido de dignidade pessoal, e se ele possui honra, esses sentimentos não se sobrepõem à proteção pessoal cedida pelos Gomes. Aderindo à intrincada rede da sociedade patriarcal, ele vê os princípios morais do sujeito austero como teoria vã no plano da prática clientelista. $\mathrm{Na}$ visão sarcástica do narrador, Antunes "entendia que há larga ponderação de males e bens", mas ele prefere simplificar, deixar a filosofia da moral humana à margem de si, e encontrar as vantagens pessoais oferecidas, os bens auferidos, por meio da submissão aos desmandos patriarcais. Sua motivação pessoal de ordem prática afasta-se do orgulho pessoal de sua filha, recoberto de um temperamento severo. Antunes preocupa-se mesmo com seu bem-estar, uma vida tranquila e sem esforços, submetendo-se, assim, ao poder da ordem clientelista.

\footnotetext{
${ }^{92}$ Cf. BOSI, Alfredo. Op. cit.

${ }^{93}$ MACHADO DE ASSIS. Iaiá Garcia. Op. cit., 2008, p. 525.

${ }^{94}$ Ibidem, p. 522.
} 
Já a postura severa da filha de Antunes, representada com ênfase pelo narrador, estrutura a compreensão da personagem enquanto um sujeito em conflito íntimo. Estela possui um comportamento incompatível com a estrutura patriarcal fortemente presente no romance. ${ }^{95}$ A diferença entre sua postura rígida e as relações de cooptação e favor do espaço social em que vive causa-lhe uma contradição íntima, pois ela quer preservar seu princípio moral, seu valor pessoal, mas vive nas malhas da relação de dependência para com os Gomes. Esse conflito pessoal intensifica-se, sobretudo, após se apaixonar pelo herdeiro Gomes, um representante da classe proprietária cujo poder contraria o rígido princípio moral da jovem.

Atenta a sua origem e, sobretudo, participando da intimidade da família Gomes, Estela conhece a postura e a mentalidade patriarcal de Jorge, a qual o narrador expõe claramente apenas no quarto capítulo do romance no momento em que o rapaz reflete sobre a possibilidade de um matrimônio com a filha de Antunes. "Não ias descer; ias fazê-la subir." 96 Dessa reflexão íntima de Jorge, ressalta-se a sua posição de "senhor", homem de posses, que enxerga Estela como a "agregada da casa". Na concepção do herdeiro Gomes, a jovem de origem humilde deve aceitar as suas investidas, ceder ao seu desejo de possuí-la, porque ele representa um homem de estrato superior. O seu status social, o seu poder supostamente legitimado pela distinção, então, é o elemento pelo qual ele age, imbuído pela ideia de prestar um favor à mulher desejada, que, pobre, deveria aceitá-lo como marido e submeter-se ao seu mando.

Dessa maneira, a rigidez de princípio da personalidade de Estela não aceita a postura de Jorge. Relacionar-se com um homem que a vê pela óptica da "mera agregada", dando continuidade à relação de dependência entre ela e os Gomes, soa-lhe como uma injúria. Os obséquios prestados por tal família já lhe são suficientes, "sua taça de gratidão estava cheia". ${ }^{97}$ No pensamento de Estela, se cedesse a Jorge, ela entraria em uma relação baseada na desigualdade de estrato social, não apenas reiterando sua dependência aos Gomes, como também forçando-a a assumir uma postura social dissimulada na posição de esposa de um rico herdeiro. Essa interpretação do pensamento de Estela pode ser comprovada no romance quando ela tece algumas considerações sobre sua relação com Luís Garcia à Iaiá: "Não vi nenhuma porta abrir-

\footnotetext{
${ }^{95}$ Cf. SCHWARZ, Roberto. Op. cit.

${ }^{96}$ MACHADO DE ASSIS. Iaiá Garcia. Op. cit., 2008, p. 532.

${ }^{97}$ Ibidem, p. 525.
} 
se-me por obséquio, nenhuma mão apertou a minha por simples condescendência. Não conheci a polidez humilhante nem a afabilidade sem calor."98 Apesar do seu casamento com Garcia ser um arranjo social (questão tratada mais adiante), nele Estela não se sente socialmente humilhada e nem fica devendo algum favor ao marido, já que ambos pertencem ao mesmo estrato social. No entanto, a despeito de escolher Luís a Jorge, Estela se envolve afetivamente com o herdeiro dos Gomes.

\begin{abstract}
Estela amava-o. No instante que descobriu esse sentimento em si mesma, pareceu-lhe que o futuro se lhe rasgava largo e luminoso; mas foi só nesse instante. Tão depressa descobriu o sentimento, como tratou de o estrangular ou dissimular - trancá-lo ao menos no mais escuro do coração, como se fora uma vergonha ou um pecado.

"Nunca!" jurou ela a si mesma." 99
\end{abstract}

Neste excerto do romance, Machado de Assis dialoga com o ideal amoroso proposto pelo romantismo. Na concepção deste movimento estético, o amor é considerado “[...] um valor em si, independente de ligações com quaisquer outros interesses humanos ou mundanos."100 O sujeito apaixonado venera o seu sentimento como um elemento superior à racionalidade humana e, também, uma força subjetiva distinta do desejo carnal. Opondo-se ao desejo, à posse, o amor torna-se elegia metafísica de um sentimento incorruptível na sua essência, porque, sendo um elemento espontâneo da subjetividade humana, não se deixa envolver pela prática cotidiana ou necessidade física do homem. O sujeito do amor romântico, tendo o sentimento como fim em si mesmo, acabou por dissociar a alma do corpo, o amor do sexo, por acreditar na dualidade bem versus mal. ${ }^{101}$

Essa idealização amorosa corresponde à descrição do comportamento de Estela ao se perceber apaixonada por Jorge. Mesmo conhecendo a maneira patriarcal com a qual o filho de Valéria a vê e a deseja, o sentimento da filha de Antunes é descrito incisivamente pelo narrador onisciente: "amava-o"; e essa disposição emocional representa um valor espontâneo, nobre, superior às relações sociais inscritas nas atitudes e visão que faz Jorge da relação afetiva. Assim, mesmo consciente da possibilidade de concretizar a sua paixão pelo rapaz, Estela prefere trancafiar o sentimento "no mais

\footnotetext{
${ }^{98}$ Ibidem, p. 617.

${ }^{99}$ Ibidem, p. 525.

${ }^{100}$ COSTA, Jurandir Freire. Sem fraude nem favor: estudos sobre o amor romântico. Rio de Janeiro: Rocco, 1998. p. 36.

${ }^{101}$ Cf. LEITE, Dante Moreira. Lucíola: teoria romântica do amor. In: outros temas. 2. ed. São Paulo: Editora Nacional / Edusp, 1979. p. 54-58. O amor romântico e
} 
fundo do coração", a fim de não descaracterizá-lo como algo sublime, "luminoso". Consoante à idealização afetiva do movimento romântico, no qual o amor é entendido como um sentimento imanente ao homem, ${ }^{102}$ a jovem vê na possível relação com Jorge somente "vergonha ou um pecado".

Frente a esse comportamento de Estela, o narrador não será irônico, crítico ou galhofeiro, porque, no decurso da narrativa, nenhuma outra personagem, ou mesmo as atitudes da filha de Antunes, depõem contra o amor da jovem, declarado pelo narrador onisciente. Pelo contrário, o narrador ratifica o ideal amoroso da personagem no final do romance quando sumariza o diálogo entre Antunes e Estela, no qual ela diz ao seu pai seu motivo para ir morar em São Paulo. "[...] contou-lhe [ao pai] a paixão de Jorge [...]; mostrou-lhe com calor, com eloqüência, que, recusando ceder à paixão de Jorge, sacrificara algumas vantagens ao seu próprio decoro; sacrifício tanto mais digno de respeito, quanto que ela amava naquele tempo o filho de Valéria." ${ }^{, 103}$ A personalidade rígida de Estela supervaloriza o amor, optando por preservá-lo das relações usurpadas do clientelismo. Assim, ela permanece firme e determinada no seu princípio de não permitir que o seu afeto deixe-se corromper e, como saída final, muda-se do Rio de Janeiro para ainda resguardá-lo. Nessas circunstâncias, o estoicismo ${ }^{104}$ vale a ela como "broquel de diamante", que lhe preserva a dignidade moral diante do autoritarismo com o qual Jorge lhe tenta dominar.

Dessa maneira, vivendo na dependência social dos Gomes, ela aceita os benefícios prestados por essa família e, somente após um beijo roubado por Jorge, sua "injúria máxima”, ela decide se afastar da casa dele; situação temporária, porque, com a partida do rapaz à Guerra, ela volta a conviver com Valéria Gomes. Contudo, amando Jorge, Estela se sente ofendida ao compreender que a contrapartida do rapaz se sustenta no dispositivo social de diferença classe. $\mathrm{Na}$ mentalidade da filha de Antunes, essa constatação nutre e insufla a segunda força atuante no espírito da jovem: sua moral. Ela não aceita ser humilhada pela sua condição social, assim como supervaloriza o seu

\footnotetext{
${ }^{102}$ Cf. COSTA, Jurandir Freire. Op. cit., 1998.

${ }^{103}$ MACHADO DE ASSIS. Iaiá Garcia. Op. cit., 2008, p. 621.

${ }^{104}$ Cf. BOSI, Alfredo. Op. cit.
} 
amor, uma "[...] conduta [que] tem um coisa canina e comovente, que não quer ser judiada, não quer morder e não quer também sair de perto."

Conhecendo o desejo de Jorge por si, Estela preocupa-se ainda com a atitude desfavorável da matriarca Gomes ao desconfiar dos anseios do filho. A relação de intimidade com a viúva dá à jovem a possibilidade de compreender que Valéria jamais aceitaria ter por nora uma jovem de outra classe social e nem ela se indisporia com a protetora por conta de uma paixão. Consciente a respeito da estratificação social em que vive, e, nesse sentido, consciente também do posicionamento da mãe de Jorge, Estela demonstra conhecer bem a sua situação de "simples agregada". Nessa posição, ela prefere evitar a presença de Jorge a concretizar os seus sentimentos, dando margem de manobra à Valéria, que trabalha pela manutenção do prestígio familiar planejando o casamento do filho.

Definido pela autoridade paterna, o casamento até meados do século XIX era um mecanismo que preservava o poder patrimonial da família e, consequentemente, o status social. A união de um homem e uma mulher dava-se pelo intercâmbio da riqueza entre as famílias. Casar significava transferir posses, repassar o patrimônio, e neste caso a mulher representava um problema de ordem econômica, pois, supostamente passiva e inferior ao homem, ela deveria ser acolhida pela família do futuro marido, levando consigo um dote como forma de pagamento pelos seus custos. A fim de reduzir as perdas patrimoniais, muitos patriarcas reduziam as uniões conjugais ao círculo parental. Assim, casamentos consanguíneos, às vezes com grande desproporção de idade entre os noivos, representaram uma prática predominante nas famílias de algum poder e privilégio. $^{106}$

Com esse propósito, após uma excursão à propriedade da família na Tijuca, onde Jorge beijara Estela, Valéria percebe o acanhamento do filho e o abatimento da "agregada" e logo conjectura: “[...] se a moça lhe amasse o filho: ou seria a queda de Estela, que a viúva estimava muito, ou o consórcio dos dois, solução que repugnava aos sentimentos, idéias e projetos. Jamais consentiria em semelhante aliança. Urgia pronto remédio." ${ }^{107}$ Seguindo o modelo matrimonial patrimonialista, no qual o chefe do agrupamento

\footnotetext{
${ }^{105}$ SCHWARZ, Roberto. Op. cit., p. 186.

${ }^{106}$ Cf. COSTA, Jurandir Freire. Op. cit., 2004.

${ }^{107}$ MACHADO DE ASSIS. Iaiá Garcia. Op. cit., 2008, p. 529.
} 
familiar designa a escolha dos novos casais, Valéria sugere ao filho um casamento com a parenta distante da família (Eulália), como prescrevia o discurso patriarcal. ${ }^{108}$ Diante da negativa do rapaz, ela pensa na separação física de Jorge e Estela e, após enviá-lo à guerra, usa o seu domínio pessoal sobre Estela para articular e orientar o casamento da moça com Luís Garcia, com o fim único de satisfazer um capricho pessoal. Na posição de proprietária, ela quer preservar o prestígio familiar, extirpando qualquer ligação entre o filho e a "agregada".

Depois de cooptar Antunes com a oferta do dote à filha, Valéria intimida Estela sobre a necessidade do casamento impondo-se à jovem: "Meteu-se-me em cabeça que hei de descobrir uma jóia. Se eu encontrar, que farás tu?" "109 Mesmo resistindo por algum tempo, alegando que não ama ninguém, Estela cede à imposição da viúva, mas sem deixar de ressaltar que seu casamento sustentar-se-ia em "um pouco de estima, certo interesse...". Esses valores atribuídos ao possível relacionamento orquestrado por Valéria reforçam o laço social entre as duas, porque, afirmando-os, Estela dissimula o seu sentimento, o seu amor por Jorge, e ratifica as convenções sociais da protetora. Na concepção da viúva, "estima e interesse" têm um caráter menos inglório, porque o sentimento amoroso para ela nasce a partir desses dois valores que representam, na união conjugal, a "semente do amor". Para Valéria o amor não significa a valorização do sentimento, mas um aspecto delimitado pelo interesse social.

$\mathrm{Na}$ afirmação de Estela de que para o matrimônio era-lhe necessário apenas "um pouco de estima, certo interesse", nota-se o cuidado da moça ao se dirigir à amiga. Sua resposta evidencia a contrariedade de seu temperamento ao ouvir a sugestão de casamento ofertada por Valéria, afinal a opinião de Estela sobre o amor diverge amplamente da opinião da amiga. A filha de Antunes não está disposta a absorver de um só golpe as convenções sociais sustentadas pela outra e abstrair sua honra pessoal e sua crença no amor. Entretanto, a jovem cede à pressão da matriarca, confirmando sua dependência em relação à amiga, bem como, aceita um casamento acordado sob as regras patrimonialistas manipuladas por Valéria, que lhe paga pelo casamento dando-lhe um dote.

\footnotetext{
${ }^{108}$ Cf. COSTA, Jurandir Freire. Op. cit., 2004.

${ }^{109}$ MACHADO DE ASSIS. Iaiá Garcia. Op. cit., 2008, p. 540-541, grifo nosso.
} 
Por sua vez, este obséquio desagrada Estela, que o recebe com uma expressão apática, porque ela compreendia-o como um benefício vindo da "mesma bolsa" da origem da afronta; “[...] uma espécie de perdas e danos que a mãe de Jorge liberalmente lhe pagava, uma água virtuosa que lhe lavaria os lábios dos beijos que ela forcejava por extinguir [...]" ${ }^{110}$ Ao fim e ao cabo, a filha de Antunes se vê humilhada, porque o dote representa um mecanismo ao qual ela se submete para mudar de vida, rebaixando o princípio altivo de exaltação do seu valor pessoal. Contudo, tanto Estela como Valéria dissimulam seus comportamentos a fim de evitar tratar do desgosto da moça, que fica em um segundo plano, obscuro e silencioso. Assim, o interesse de Valéria em dar curso a sua vontade de separar definitivamente o filho da "agregada" repercute na convivência com Estela que, querendo afastar Jorge de si, encontra no casamento arranjado pela amiga uma possibilidade de automanutenção.

O empenho de Valéria em forçar o matrimônio da filha de Antunes ganha sustentáculo quando a moça diz ter achado "um projeto de marido" em Luís Garcia e, imediatamente, a viúva assume as rédeas da situação e afirma à outra: “- Não deves fazer nada; incumbo-me de tudo." 111 Portanto, essa união efetiva-se por meio do domínio e do capricho de Valéria, tanto sobre a jovem, quanto sobre Luís Garcia, cabendo a Estela apenas a indicação do marido, que se dá pelo frio julgamento da apreciação da figura de Garcia: "De tudo o que observava [nele] concluía que a sobriedade era a lei moral desse homem, e que à taça da vida não pedia mais do que alguns goles, poucos." ${ }^{\text {,12 }} \mathrm{O}$ eleito podia não ser semelhante a ela, "[...] mas Estela podia fiar do tempo que ajusta contrastes", ${ }^{113}$ porque se a sobriedade de Garcia poderia não ser equivalente à rígida moral dela, porém, sendo do mesmo nível social, não lhe ficaria devendo o obséquio da ascensão, portanto o matrimônio para ambos "foi escolha da razão, e por isso acertada". 114

- Creio que nenhuma paixão nos cega, e se nos casamos é por nos julgarmos friamente dignos um do outro.

- Uma paixão de sua parte, em relação à minha pessoa, seria inverossímil, confessou Luís Garcia; não lha atribuo. Pelo que me toca, era igualmente inverossímil um sentimento dessa natureza, não porque a senhora o não pudesse inspirar, mas porque eu já o não poderia ter.

\footnotetext{
${ }^{110}$ Ibidem, p. 540, grifo nosso.

${ }^{111}$ Ibidem, p. 543.

112 Ibidem, p. 542-543.

${ }^{113}$ Ibidem, p. 543.

${ }^{114}$ Ibidem, p. 617.
} 
- Tanto melhor, concluiu Estela; estamos na mesma situação e vamos começar uma viagem com os olhos abertos e o coração tranqüilo. Parece que em geral os casamentos começam pelo amor e acabam pela estima; nós começamos pela estima; é muito mais seguro. ${ }^{115}$

A relação estabelecida entre Estela e o futuro marido pauta-se pela igualdade social, mostrando-se esse "acerto", sem privilegiar a ligação sentimental, conveniente para ambas as partes: Estela consegue impor uma barreira entre si e Jorge por meio de um casamento que lhe garante o conforto social, sem colocar em relevo a sua origem humilde; enquanto Garcia consegue uma esposa dedicada e, ao aceitar o compromisso orquestrado por Valéria, conquista o dote para Iaiá. Nessas circunstâncias, a união de Estela e Jorge representa um problema de conjectura social, porque ambos confirmam a "inverossimilhança" do laço afetivo. Entre eles interpõe-se a força da estratificação social e a submissão ao mando da matriarca Gomes.

No entanto, na decisão de casar-se com Luís Garcia, Estela não apenas aceita as convenções sociais; sua escolha explicita a contradição encerrada na sua personalidade, pois ao querer afastar-se do obséquio prestado por Jorge, negando-lhe a correspondência afetiva, ela aceita o favor prestado por Valéria, que lhe dá o dote. Mesmo se esforçando, posteriormente, para manter seu princípio de honra pessoal quando doa esse benefício da viúva para a afilhada, prova de seu desinteresse e desapego, Estela não se desliga das relações de cooptação e, sobretudo, deixa entrever no seu comportamento a relação baseada na conveniência. Ela aceita o casamento como instrumento de fuga do amor e respaldo social. ${ }^{116}$

A fim de ressaltar a personalidade de Estela, é importante, também, deter-se na visão de Garcia sobre a futura esposa. Refletindo sobre o modo como se comporta a jovem, ele depura a compleição de Estela por meio de um aspecto que reafirma-lhe o traço romântico já descrito pelo narrador, e tratado anteriormente neste mesmo capítulo. Sem minúcia de descrição, ele apenas sinaliza para o que parece ser a aparência física da jovem. O "ar de tristeza habitual""117 de quem "devia padecer ou ter padecido alguma vez"118 atribuía ao perfil de Estela uma moldura das donzelas cloróticas, de semblante sofrido. Garcia, então, a vê por meio da óptica de um romantismo melancólico, cujo

\footnotetext{
${ }^{115}$ Ibidem, p. 546.

${ }^{116}$ Cf. BOSI, Alfredo. Op. cit.

${ }^{117}$ MACHADO DE ASSIS. Iaiá Garcia. Op. cit., 2008, p. 545.

${ }^{118}$ Ibidem, p. 545.
} 
sofrimento pessoal torna-se uma característica singular "[...] das personagens bem definidas, moral e psicologicamente bem organizadas"119 do romantismo brasileiro.

Nesse semblante de tristeza de Estela soma-se a qualidade moral do "[...] resguardo com que ela procedia, sem ostentar a intimidade de Valéria, nem cair nos ademanes da servilidade." ${ }^{120}$ Esse comportamento da jovem soa verdadeiro para Garcia, porque, conhecendo-a no convívio da casa dos Gomes, ele pode compreender e acreditar nas maneiras dela. Porém, para ele, os valores da filha de Antunes eram contrário à época em que viviam, soando-lhe "caduco". A sua futura esposa teria uma severidade de comportamento atípico, uma postura de honra e princípio moral em desarmonia com o meio social clientelista, no qual os valores margeados pela coerção do poder proprietário usurpam as escolhas pessoais.

Assim, Machado de Assis problematiza a vida da personagem Estela, porque apesar de desejar realizar seu amor pelo homem amado, ela se depara com o obstáculo da estrutura patrimonialista. Ao fim, sua escolha pelo casamento arranjado entra em consonância com o princípio da sociedade patriarcal, na qual "o casamento não celebrava [...] o reconhecimento social da união amorosa entre indivíduos. O amor não era um pressuposto necessário à ligação conjugal. Como, aliás, a atração física, cuja ausência ou presença em nada alterava a composição da aliança." ${ }^{121}$ Nesse sentido, Estela prefere preservar o seu sentimento, negando o seu amor por Jorge, ainda quando pressionada diretamente por Valéria, a quem a jovem guarda certa consideração pela proteção outorgada.

Ao preterir Jorge a Luís Garcia, a troca do sentimento pela razão, ela não fere a sua autoestima. $\mathrm{O}$ amor não se realiza, e a conveniência prevalece na escolha da relação conjugal. Apesar de querer ostentar uma "virilidade moral", Estela não consegue romper com as amarras sociais, e a sua severidade moral, voltada para a supervalorização do sentimento como um bem a ser preservado, mostra-se ineficiente e "caduca". Estela ainda acredita na nobreza de uma "virtude inteiriça"122, cujo caráter austero não permitisse a invasão das convenções sociais, o conflito do mundo exterior.

\footnotetext{
${ }^{119}$ LEITE, Dante Moreira. Op. cit., p. 54.

${ }^{120}$ MACHADO DE ASSIS. Iaiá Garcia. Op. cit., 2008, p. 545.

${ }^{121}$ COSTA, Jurandir Freire. Op. cit., 2004. p. 216.

${ }^{122}$ MACHADO DE ASSIS. Iaiá Garcia. Op. cit., 2008, p. 572.
} 
Porém, no contexto de uma sociedade norteada pelas relações de dependência e pelo patrimônio, o amor (idealizado por certo romantismo) e o matrimônio se excluem mutuamente. Assim, a cooptação tende a dar um forte impulso nas relações entre os indivíduos, levando-os à frustração amorosa, o que Estela confirma ao responder à dúvida de Iaiá sobre se deveria casar-se com um homem amando a outro: "Não deves casar, se o amor pode ser satisfeito sem obstáculo. No caso contrário, o casamento é uma simples escolha da razão: sacrifica-te."123

Em tempo, para compreender o "drama que o romance pretende narrar" 124 , a relação afetiva entre os pares Estela e Jorge e Jorge e Iaiá Garcia, cumpre-se detalhar o processo progressivo do desejo de Jorge por Estela. Nesse sentido, após concluir os seus estudos de direito em São Paulo, ele volta a morar na casa materna, onde encontra a moça inserida como agregada, e "a fantasia sensual no primeiro instante" provoca-lhe o instinto sexual. Jorge, então, “[...] fala-lhe com olhos - linguagem que a moça não entendia, ou fingia não entender."125 Assim, Estela procura evitá-lo fazendo-se de desentendida, como se não compreendesse o olhar voraz de Jorge que não desiste do seu intento de possuí-la. Astuto e irredutível no seu desejo, ele tenta convencer Valéria a evitar a presença da "agregada da casa", alegando ter a moça "boas qualidades", mas ser um "tropeço" para a família por ser "uma pessoa estranha metida"126 entre eles. Com isso, o rapaz dissimula o seu interesse pela jovem, a fim de conseguir espaço para assediá-la, como conclui o narrador:

O que [Jorge] acabava de dizer não passava de uma tentativa sincera, mas frouxa, para arredar Estela da casa; era o imposto pago à consciência. Quite com ela entregou-se aos acontecimentos, confessando a si mesmo que o perigo não era tão grave, nem o remédio tão urgente; finalmente, que ele era homem. ${ }^{127}$

A atitude de afastar a "agregada" da casa encerra a motivação de Jorge, que enxerga a mulher somente como um objeto sexual. Vendo-a pelo filtro do instinto e da mentalidade patriarcal, afinal "ele era homem", o herdeiro dos Gomes coloca a execução dos seus desejos acima de qualquer outra regra e, quando conversa com Valéria, ele apenas mostra a sua face de proprietário. Ao alertar a sua mãe da

\footnotetext{
${ }^{123}$ Ibidem, p. 569.

${ }^{124}$ Ibidem, p. 524.

${ }^{125}$ Ibidem, p. 524, grifo nosso.

${ }^{126}$ Ibidem, p. 525.

${ }^{127}$ Ibidem, p. 525.
} 
necessidade de banir a jovem da casa, ele reforça a diferença de estrato social entre a sua família e Estela. No entanto, "o remédio não era urgente", porque ele não pretendia afastar-se da jovem. Ele apenas finge um sentimento contrário ao seu desejo; o narrador, por sua vez, irônico, dá o tom à cena ao dizer que a atitude de Jorge "era [lhe] o imposto pago à consciência".

Vagando uma propriedade da família Gomes na Tijuca, Valéria, Jorge e Estela vão visitar o imóvel, onde o rapaz consegue passar algum tempo sozinho com a moça. Enquanto a viúva confere com o pedreiro os danos causados pelo antigo inquilino, Jorge aproveita para, interpondo-se entre Estela e a saída da varanda onde estão, interpelar a moça no intuito de conseguir uma resposta afirmativa sobre o amor que supostamente existiria entre ambos. Impulsivo e ávido por tê-la como um mero objeto, ele a acusa de "disfarçada", como se ela dissimulasse o próprio sentimento, do qual ele não esta seguro uma vez que Estela age friamente: "Deixe-me passar - disse ela sem cólera nem súplica." Se à investida do olhar de Jorge, Estela conseguia fazer-se de desentendida, agora, com a postura de mando do rapaz, ela precisa ser mais objetiva e, segura de si, ignorando-lhe a ordem.

\footnotetext{
Não insistiu Estela, mas ficou diante dele, quieta e sem arrogância, como esperando ser obedecida. Jorge quisera-a suplicante ou desvairada; a tranqüilidade feria-lhe o amor-próprio, fazendo-lhe ver que o perigo era nenhum, e revelando, em todo caso, a mais dura indiferença. Quem era ela para o afrontar assim? Era a segunda vez que formulava essa pergunta; tinha-a feito antes nas primeiras auroras da paixão. Mas desta vez a resposta foi deplorável. ${ }^{128}$
}

Como sua mãe, Jorge se baseia na sua "autoridade senhorial" e não mede esforços para conquistar o que deseja, pretendendo, assim, ser o senhor da "agregada". Imperativo, ele tenta intimidar Estela, ameaçando-a com a possibilidade de uma futura represália por sua recusa. "Cravando os olhos em Estela, disse com voz trêmula, mas imperiosa: 'Não há de sair daqui, sem me dizer se gosta de mim. Vamos; responda! Não sabe o que lhe pode custar esse silêncio?'[...] saiba também que posso tirar vingança de seus desprezos, e chegarei a ser cruel, se for necessário." ${ }^{, 129} \mathrm{Na}$ sua expressão de ira, despeito diante da atitude negativa e de superioridade moral da mulher desejada, confirma-se a sua visão sobre Estela como sendo de condição inferior, de estrato social diferente, na qual ele se

\footnotetext{
${ }^{128}$ Ibidem, p. 527, grifo nosso.

${ }^{129}$ Ibidem, p. 527.
} 
baseia para tê-la como posse da família. A princípio, é esse sentimento que o leva a querer a filha de Antunes, como objeto, ficando explícita a inexistência de um traço afetivo em seu temperamento.

Em outro traço do modo de ação de Jorge, a sua personalidade autoritária coaduna-se com sua capacidade imaginativa, nomeada pelo narrador de "grão de romanesco"130. A faculdade de abstrair-se completamente da realidade em função do provável, do verossímil, ao definir suas escolhas afetivas. Assim, "Estela freqüentava-lhe tenazmente a memória; e na rua, no teatro, nas assembléias a que ia, o perfil severo da moça vinha meter-se entre ele e a realidade." ${ }^{131}$ Tomado por essa fixação na imagem da jovem e respaldando-se na sua suposta superioridade social Jorge, em busca da satisfação física, rouba um beijo de Estela. A esse ato abusivo, sua "máxima injúria", a jovem reage friamente em defesa de seus princípios. Austera, ela evitava os olhares insinuantes do rapaz. A determinação moral com a qual a moça age diante dessas investidas levam Jorge ao fascínio por ela. Por fim, a indiferença de Estela intensifica paulatinamente o pendor imaginativo de Jorge, porque, da sua posição autoritária, ele não compreende o motivo das negações de Estela, passando, então, a cultivar na sua imaginação o "mistério" do comportamento da filha de Antunes.

Essa tendência de Jorge em dar margem à imaginação se desenvolve progressivamente na narrativa, sobretudo depois que, aviltada pelo ato de desonra cometido pelo rapaz, Estela decide regressar à casa paterna. "A separação não valia nada ou valia cousa pior; fez recrudescer o amor de Jorge, por isso mesmo que entre um e outro rasgava espaço à imaginação. Duas forças reagiram no coração do rapaz; o obstáculo, que tornava mais intenso o amor, e o remorso que o fazia respeitoso." ${ }^{132}$ Nesse sentido, a distância imposta pela filha de Antunes não dilui o interesse de Jorge, pelo contrário, serve-lhe como mecanismo de impulsão ao amor. Ele compreende a afronta que o beijo forçado representou para o temperamento de Estela, porque ela, supostamente, esperava dele uma atitude cortês, um gesto de amor cavalheiresco. Por meio dessa compreensão, o rapaz começa a mudar a índole do seu sentimento, tornando-se "respeitoso" e idealizando a imagem da mulher a qual ele começa a amar.

\footnotetext{
${ }^{130}$ Ibidem, p. 523.

${ }^{131}$ Ibidem, p. 524-525, grifo nosso.

${ }^{132}$ Ibidem, p. 529, grifo nosso.
} 
A figura severa da filha de Antunes ocupa a memória de Jorge que passa a desenvolver uma idealização crescente e vigorosa da moça. Ele fantasia a sua figura de acordo com o modelo de mulher de índole cortês. Para Jorge, Estela quer ser cortejada por um homem socialmente ilustre, de atos nobres, que viria a conquistá-la por meio de uma declaração de amor grandiosa, como um feito de amor guerreiro à moda medieval. Nessa perspectiva, a mentalidade do herdeiro Gomes se associa à construção do amor como um feito masculino, legitimado pelo discurso patriarcal. Nesse intuito, a proposta de sua mãe ao querer vê-lo nas frentes de batalha da Guerra do Paraguai torna-se para ele uma motivação capaz de sensibilizar a postura severa de Estela.

Da sua perspectiva social, ele não compreende que o temperamento determinado de Estela é uma resposta à sua condição social de agregada, sem relações com a autoestima de Jorge como um homem imponente, nobre cavalheiro romantizado. No momento em que ele a procura para dizer-lhe a sua resolução de ir à Guerra, apenas ouve em tom irônico: “- O senhor é um tonto." 133 Atordoado, e sem compreender a resposta da filha de Antunes, a quem ele imaginava ter vencido a personalidade com a proposta de lutar bravamente por ela, o rapaz volta para casa. "O coração batia-lhe rijo na arca do peito; de quando em quando o corpo era tomado de calafrios. Ia despeitado, humilhado, com um dente de remorso no coração."134 O sentimento de amor, o coração batendo-lhe no peito, suplantara o antigo desejo sensual. A idealização da jovem como a mulher a ser esposada ocupara um lugar mais nobre, distante da atração sensual provocada pela primeira impressão. Assim, a negativa de Estela não lhe soa como afronta ao status social, mas como menosprezo do sentimento amoroso.

Com um "espírito elástico e móbil"135, Jorge espanta-se com as firmes negativas de Estela e se lança na Guerra, vendo no perigo “[...] não a morte obscura ou ainda gloriosa, mas o triunfo e o laureado regresso." ${ }^{, 136}$ Dessa maneira, a Guerra para Jorge não representa apenas a conquista do amor de Estela, mas também o "brilho" social de uma futura patente. Por meio de cálculo, ele conjectura que se Estela não lhe retribuísse o "feito heroico" correspondendo-lhe afetivamente, ele ao menos conquistaria uma

\footnotetext{
${ }^{133}$ Ibidem, p. 531.

${ }^{134}$ Ibidem, p. 532.

${ }^{135}$ Ibidem, p. 534.

${ }^{136}$ Ibidem, p. 534.
} 
patente de oficial, reafirmando-lhe o status social. Isto é, ao decidir participar dessa empreitada guerreira, Jorge age racionalmente em nome do amor e do interesse pessoal.

Contudo, durante a batalha no Paraguai, "[...] o coração de Jorge padecera grande transformação." 137 O limite imposto entre si e Estela pela Guerra leva o espírito do rapaz a aumentar ainda mais o seu amor, o que é relatado da seguinte forma em carta a Luís Garcia.

\begin{abstract}
A paixão veio comigo apesar do que lhe ouvi na véspera de embarcar; e se não cresceu, é porque não podia crescer. Mas transformou-se. De criança tonta, que era, fez-se homem de juízo. Uma crise, algumas léguas de permeio, poucos meses de intervalo, foram bastantes a operar o milagre.

[...] Se a vir, ignoro os sentimentos com que ela me receberá. Mas de um ou de outro modo, este amor morrerá comigo, e o seu nome será a última palavra que há de sair de meus lábios.

Meu amor não sabe já o que seja impaciência ou ciúme ou exclusivismo: é uma fé religiosa, que pode viver inteira em muitos corações. Talvez o senhor me não compreenda. [...] Eu mesmo não sei explicar o que sinto, mas sinto alguma coisa nova, uma saudade sem esperança, mas também sem desespero: é o que me basta. ${ }^{138}$
\end{abstract}

Isolado do universo fluminense, a sua admiração pela moça transforma-se em adoração. Após longo período afastado de Estela, sua capacidade imaginativa impulsiona e insufla sua admiração por ela. Durante o período de Guerra, no espaço vago deixado pela distância da jovem, cria-se uma imagem calcada na sobreposição das lembranças. A admiração por Estela recrudesce e infunde-se no espírito de Jorge. Como um cavalheiro de uma novela medieval, isolado na Guerra, Jorge tem a sua mente e coração voltados para a mulher amada como "uma fé religiosa". Num movimento progressivo, o sentimento de Jorge por Estela inicia-se com o impulso sexual, alterna-se em idealização, cedendo espaço ao culto da imagem de "donzela", até desembocar em adoração mística.

No Paraguai, Jorge sonha acordado, quando não está em batalha, traçando estrelas no chão com a ponta da espada à luz do meio-dia. Metaforicamente, os seus desenhos simbolizam a moça, quer pela semelhança da grafia entre estrela e Estela, quer pela aproximação de uma posição constelada e inatingível ocupada pelo corpo celeste. "Jorge era, não só taciturno, mas desigual, ora dócil, ora ríspido, muitas vezes distraído

\footnotetext{
${ }^{137}$ Ibidem, p. 535.

${ }^{138}$ Ibidem, p. 535-536, grifo do autor.
} 
e absorto"139 e a sua maneira de ver Estela converte-se "[...] em uma espécie de adoração mística, sentimento profundo e forte, que parecia respirar atmosfera mais alta que a do resto da criação." ${ }^{140}$ Assim, ele já não ama uma mulher, mas o ideal da mulher erigido em sua mente, como se ela fosse um modelo a ser cultuado; ideal descrito por Stendhal como o "amor-gosto", que "é um quadro em que tudo, até as sombras, deve ser cor-de-rosa, onde nada de desagradável deve entrar sob nenhum pretexto e sob pena de pecar contra os costumes, o bom-tom, a delicadeza, etc."141

Nesse momento da narrativa, Machado de Assis desdenha a figura romântica sonhadora e apaixonada, como faria anos depois em Quincas Borba, na cena em que Rubião contempla "a lua [que] era magnífica" 142 acompanhado da bela Sofia no jardim da casa da jovem. Completamente envolvido por ela, "Rubião lembrou-se de uma comparação velha, mui velha, apanhada em não sei que décima de 1850, ou qualquer outra página em prosa de todos os tempos. Chamou aos olhos de Sofia as estrelas da terra, e às estrelas, os olhos do céu. Tudo isso baixinho e trêmulo." 143 Porém, Sofia, que não ignora o sentido "das finezas do homem"144, apenas quer tê-lo longe de si. "Mas confessar que entendia, e não despedi-lo de casa, eis aí o ponto melindroso"145 já que ela está interessada nas posses do amigo. Situação que a idealização do sonhador Rubião não lhe permite nem ao menos imaginar.

Para determinar as motivações que levam Jorge a se apaixonar por Estela, Machado de Assis dialoga com a visão do amor proposta por Stendhal, na qual esse sentimento afetivo se desenvolve a partir de uma eleição pessoal, uma motivação de interesse particular do homem que, intensificado pela ausência ou negação da mulher preterida, cristaliza o amor por meio da capacidade de fantasiar a realidade. Nesse pressuposto, o sujeito apaixonado "[...] já não a vê tal qual ela é realmente, mas sim tal como lhe convém que ela seja." ${ }^{146}$ Partindo da imaginação romântica como elemento para compreender o amor, Stendhal redefine-o pelo nome de cristalização ao explicar a sensação de estar apaixonado.

\footnotetext{
${ }^{139}$ Ibidem, p. 535, grifo nosso.

${ }^{140}$ Ibidem, p. 535.

${ }^{141}$ STENDHAL. Op. cit., p. 3.

${ }^{142}$ MACHADO DE ASSIS. Quincas Borba. Op. cit., 2008, p. 790.

${ }^{143}$ Ibidem, p. 790.

${ }^{144}$ Ibidem, p. 791.

${ }^{145}$ Ibidem, p. 791.

${ }^{146}$ STENDHAL. Op. cit., p. 323, grifo do autor.
} 
Sentimos prazer em ornar de mil perfeições uma mulher de cujo amor temos certeza; passamos em revista toda a nossa felicidade com uma complacência infinita. Isso se resume em exagerar uma propriedade soberba, que acaba de nos cair do céu, que não conhecemos e cuja nos é assegurado.

Deixem a cabeça do amante funcionar durante vinte e quatro horas e eis o que encontrarão. ${ }^{147}$

Dessa proposição de Stendhal, pode-se afirmar que Jorge cristaliza o amor por Estela, pois em princípio ele a deseja carnalmente e supõe que a jovem o esteja amando, quando, um pouco antes de beijá-la, afirma que ela “disfarça!” o seu sentimento por ele. $\mathrm{Na}$ mentalidade patriarcal e sonhadora do rapaz, a negação da moça desencadeia o processo de cristalização da figura de Estela durante o período entre o primeiro contato entre eles até passagem de Jorge pela guerra. Superdimensionando a imagem da mulher amada, Jorge, então, valoriza a expressão afetiva que ela supostamente faria dele e, nesse sentido, seu foco não é mais a mulher como mero objeto sexual, mas a idealização do sentimento por ele mesmo. Em outras palavras, a noção pessoal do sujeito em busca do prazer se amplia no homem civilizado, a ponto de tornar-se um sentimento egoísta.

Depois de quatro anos na Guerra do Paraguai, ele volta para o Rio de Janeiro, sabendo, por meio da correspondência trocada com Luís Garcia, que este se casara com Estela. "Não se sentia feliz nem infeliz, mas nesse estado médio, que é a condição vulgar da vida humana." 148 O então tenente-coronel Gomes "trazia os olhos no passado e no presente; deixou ao tempo os casos do futuro." ${ }^{149}$ Tinha ele patente e uma posição social de prestígio, como já previa o narrador. A sua esperança em relacionar-se com Estela reascende quando, chamado à casa de Luís Garcia, descobre que este estava doente, tinha um problema cardíaco.

Com a doença do amigo, Jorge novamente se aproxima de Estela e, sobretudo, vislumbra a possibilidade de tê-la por esposa, presumindo a morte de Garcia. Instantaneamente o tenente-coronel ascende a sua ilusão adormecida, a sua fixação pela jovem, como também, mostra, novamente, sua face patriarcal. Ele "pensava muitas vezes na consequência de herdar em breve prazo a esposa de Luís Garcia [...]" ${ }^{\text {150 }}$ como se, a mulher de origem humilde fosse um bem a ser recebido. Uma joia idealizada na sua mente e que agora poderia, enfim, vir-lhe às mãos. Para Jorge, a sua união com

\footnotetext{
${ }^{147}$ Ibidem, p. 6-7.

${ }^{148}$ MACHADO DE ASSIS. Iaiá Garcia. Op. cit., 2008, p. 538.

${ }^{149}$ Ibidem, p. 538.

${ }^{150}$ Ibidem, p. 560.
} 
Estela seria uma reparação de ambas as partes: Estela compensa-lhe do tratamento frio com o qual o tratara, e ele repararia o "mal que lhe fizera" 151 forçando-lhe o beijo. Ao fim e cabo, seu pensamento sobre o matrimônio reafirma a ideia fixa de ter Estela e, nesse sentido, deixa entrever, novamente, a face do proprietário pensando binariamente em perdas e ganhos.

No pensamento de Jorge opera-se um processo delirante. Ignorando a frieza com a qual a amada o trata, ele chega à conclusão, ironizada por Stendhal, da posse do objeto amado como instrumento de autossatisfação: "Ela é minha."152 Estela representa para ele a insígnia da perfeição de mulher a ser esposada, um ser concebido e cultuado imaginariamente sob dois eixos: o do proprietário patriarcal e do sujeito sonhador. Nessa dupla vertente da psicologia de Jorge, Machado de Assis revê criticamente o uso proeminente, pelo movimento romântico, da idealização amorosa. Afinal, Jorge não muda a sua autoconstituição a partir da sua condição de patrimonialista e quer a todo custo possuir a amada, em uma mistura de estima e dependência social. $\mathrm{O}$ seu ato cavalheiresco de partir para a Guerra e o amor que lhe rompe na alma são o produto de uma supervalorização da sua faculdade imaginativa, devaneio que, no decorrer do enredo, dará à sagaz Iaiá Garcia a oportunidade de fisgá-lo em outro amor.

${ }^{151}$ Ibidem, p. 560.

${ }^{152}$ STENDHAL. Op. cit., p. 7. 


\section{CAPÍtULO III}

\section{IAIÁ: A AÇÃO RACIONALMENTE ORIENTADA}

Com o final da Guerra do Paraguai e a volta de Jorge ao Rio de Janeiro, Iaiá Garcia aponta, na segunda metade do livro, para novos arranjos afetivos e sociais. Após o fim da batalha, o poder patriarcal ostentado pela matriarca Gomes consegue satisfazer os seus caprichos. A ligação sentimental entre Estela e Jorge rompe-se e cada qual assume o seu lugar pré-determinado na escala social: a jovem se casa com alguém do seu nível social, e Jorge condecora o nome familiar com a titulação honorífica. A partir dessa disposição das personagens, o narrador detém-se sobre o amadurecimento de Lina Garcia e sua evolução no drama familiar.

No lugar da mulher de postura altiva e inflexível na defesa do seu caráter, firmados no comportamento de Estela, o escritor desenvolve a personalidade temperamental e perspicaz da jovem Lina Garcia e, com isso, a sua posição diante do amor e do casamento. Para melhor compreender a personalidade da filha de Luís Garcia, faz-se necessário voltar à primeira parte do romance a fim de tecer alguns comentários sobre a sua infância. Órfã de mãe, ela foi educada em um colégio para moças do centro do Rio de Janeiro e apenas tinha a companhia paterna aos finais de semana, quando regressava ao seu lar. O curto período ao lado do pai lhe rendia a efusão de afagos e carinhos de Luís Garcia, que, juntamente com Raimundo, multiplicava o afeto e zelo pela criança, tornando "o domingo [...] o dia mais festivo da semana."

Raimundo oferecia à menina jogos de adivinha, ou alguma "lembrança". "Era às vezes um confeito, outras uma fruta, um inseto esquisito, um molho de flores" $154 \mathrm{e}$, em se tratando de "[...] uma fruta ou um doce, a menina trincava-o logo, a olhar e a rir para o preto, a gesticular, e a interromper-se de quando em quando: - Muito bom! Raimundo é amigo de Iaiá... Viva Raimundo!" ${ }^{155}$ Se os agrados de Raimundo resumem-se à simplicidade da sua condição de vida, os de Luís Garcia irrompem às vezes em

\footnotetext{
${ }^{153}$ MACHADO DE ASSIS. Iaiá Garcia. Op. cit., 2008, p. 511.

${ }^{154}$ Ibidem, p. 512.

155 Ibidem, p. 512.
} 
excessos, como o piano comprado com recursos da herança da filha, após vê-la tocar um instrumento imaginário. A compra do móvel serve de parâmetro para demonstrar a personalidade de Lina Garcia.

O presente de Garcia no primeiro instante causa nela alegria, mas cede espaço, em seguida, à percepção da condição econômica da família. "Entre duas notas, Iaiá parou, olhou para o pai, para o piano, para os outros móveis; depois descaiu-lhe rosto, disse que tinha uma vertigem." ${ }^{156}$ A casa pobre, de móveis velhos e puídos, desperta o seu sentimento de constrangimento ao ver o pai despender dinheiro com um objeto caro no contexto aquisitivo familiar. Sua alegria "intensa, mas curta" ${ }^{157}$, apenas a leva a tocar o piano com notas frouxas, sem energia. No lugar de tocá-lo com a vibração entusiástica de quem acabou de realizar um grandioso sonho, ela sintetiza nas notas tiradas do teclado o abatimento de seu estado de desconforto ao ter um objeto de valor superior às posses da sua família. Dessa situação, ressalta-se na personalidade da menina a inteligência rápida, a vivacidade de espírito capaz de, por meio da observação atenta, comparar e deduzir a difícil situação econômica familiar.

Contrastando a realização do seu desejo com a vida modesta de seu pai, Iaiá deixa "descair-lhe o rosto" e diz a Garcia ter uma "vertigem". ${ }^{158}$ Com essa atitude, ela reconhece o esforço paterno em atender-lhe aos desejos pessoais ou mesmo deixar-lhe uma "herança". Iaiá compreende que o piano significa um objeto de luxo para a família, pois, do padrão social mediano em que vivem, em uma casa com móveis velhos, seu pai usufrui a mínima parte possível das suas condições, beneficiando-a com a renda poupada em banco. Por ela, Garcia decide comprar ou gastar o necessário, mesmo que para isso ele precise usar as economias, a fim de vê-la feliz. Nesse sentido, a reflexão sobre a disparidade entre o ambiente doméstico e o "lustroso piano" causa-lhe a suposta "vertigem", expressão da desordem interior provocada por essa constatação.

Porém, o desconforto que cedo penetra a alma de Iaiá, logo "passou! Bem depressa"159 e curto foi o seu instante de perturbação íntima. A aflição e a consciência da jovem deixam passar o instante de desassossego para tornar os domingos de Raimundo e

\footnotetext{
${ }^{156}$ Ibidem, p. 513.

${ }^{157}$ Ibidem, p. 513.

${ }^{158}$ Ibidem, p. 513.

${ }^{159}$ Ibidem, p. 513.
} 
Garcia novamente alegrados pela jovialidade da garota. Assim, mesmo ciente das dificuldades financeiras da sua casa, Iaiá supera rapidamente o momento de desconforto com a compra do piano e segue feliz com ele. Sempre adulada por Garcia e Raimundo, ela logo se esquece do empenho paterno em garantir-lhe um futuro seguro, retornando à alegria habitual e ao entretenimento com o instrumento musical, mostrando, com isso, um indício do que virá a ser sua personalidade voluntariosa.

Nesse momento da narrativa, Lina Garcia "contava onze anos [...] Era alta, delgada, travessa; possuía os movimentos súbitos e incoerentes da andorinha. A boca desabrochava facilmente em riso - um riso que ainda não toldavam as dissimulações da vida nem ensurdeciam as ironias de outra idade."160 Sua tenra idade reflete o comportamento travesso na medida usual de uma criança, com movimentos agitados e desarmônicos. A esse perfil acresce-se-lhe o riso fácil, ingênuo, sem disfarces; sincero, representando a sua alegria. A descrição de Iaiá distende-se, assim, compelindo um conjunto de adjetivos cristalinos que demonstram a faceirice da menina. Seu riso espontâneo e sincero, como afirma o narrador, não possui o artifício da dissimulação, o que não significa, porém, que o viço da primeira idade fizesse-a ingênua; ela "ainda" não compreende as articulações e ademanes apregoados no convívio social e, por extensão de sentido, seu amadurecimento na sociedade se encarregaria de desenvolver nela as artimanhas da dissimulação.

Em sentindo contrário à corrente discursiva dominante durante o século XIX, na qual a mulher era percebida como instrumento de reprodução da espécie, passivo e superficial e, nessa óptica, inferior ao homem ${ }^{161}$, Machado de Assis dota a sua personagem com agudeza de raciocínio. Em criança, ela já se torna apta a reconhecer as contradições sociais, supostamente distante da puerilidade. A essa característica pessoal soma-se o contexto no qual ela vive. Iaiá estuda em colégio para meninas onde recebe a educação voltada às jovens da elite fluminense. $\mathrm{O}$ aprendizado e a vivência com tantas iaiás parecem fazer diferença no comportamento da jovem, pois ela volta para casa iniciada na arte pianística. Assim, tocando um piano de "teclas ausentes", ela insinua ao pai o seu desejo pelo instrumento musical, no que é prontamente atendida e, somente algumas

\footnotetext{
${ }^{160}$ Ibidem, p. 511, grifo nosso.

${ }^{161}$ Cf. DUBY, Georges; PERROT, Michelle. Op. cit.
} 
linhas adiante no romance, o narrador esclarece o ato de Garcia: "Iaiá confiou um dia ao pai a idéia que tinha de ser mestra de piano."162

O piano - considerado como o "haxixe das mulheres" pelo escritor oitocentista francês Edmond de Goncourt - representa um ícone da elite, sobretudo como expressão de feminilidade no imaginário masculino. ${ }^{163}$ Saber dedilhar o teclado além de ser uma vocação estético-musical, passa também a mover e a articular a vida das jovens aspirantes ao matrimônio. "Tocar bem piano estabelece uma reputação juvenil, demonstra em público uma esmerada educação. O virtuosismo artístico entra na estratégia matrimonial, ao lado do 'dote estético'."164 A beleza da jovem, aliada ao domínio da técnica da musical, fortalece seus atrativos no ato de conquista do seu pretendente, porque resumem nela a insígnia de distinção social almejada pelo homem da camada dominante.

Sob os dedos inocentes da jovenzinha ignorante, o teclado traduz as pulsações que a linguagem não saberia exprimir. [...] Este aparece como exutório privilegiado da timidez; o que permite o surgimento da cena literária em que a moça, acreditando-se só, revela ao indiscreto anseios [sic] tanto mais insuspeitados, já que o instrumento tem ainda o privilégio de elevar a alma até o ideal. ${ }^{165}$

Na constituição de Lina Garcia, essa referência aproximada da personagem de ficção a certo padrão de comportamento social confere-lhe traço de realidade. Como parte das moças do seu tempo, ela possui uma formação voltada para o matrimônio. As aulas de piano agregam-lhe valor do ponto de vista social, o que a fala de Luís Garcia vem a confirmar: "Iaiá tinha por si a beleza e a instrução [...]"166 , mas isso "[...] podia não ser bastante para lhe dar casamento e família." ${ }^{167}$ Ao cabo, Garcia sintetiza o seu desejo primeiro, a preocupação íntima paterna: o de ver a filha casada e com uma posição social segura e confortável; meta de difícil alcance, porque, vivendo em uma sociedade em transição, o dote, que Iaiá não possui, ainda é um elemento de forte relevância para o aceite do compromisso de casamento.

\footnotetext{
${ }^{162}$ MACHADO DE ASSIS. Iaiá Garcia. Op. cit., 2008, p. 513.

${ }^{163}$ ARIÈS, Philippe; DUBY, Georges (Dir.). História da vida privada: da revolução francesa à Primeira Guerra. Tradução Bernardo Joffily; Denise Bottmann. São Paulo: Companhia De Bolso, 2009. v. 4, cap. 4, p. 453.

${ }^{164}$ Ibidem, p. 454.

${ }^{165}$ Ibidem, p. 454.

${ }^{166}$ MACHADO DE ASSIS. Iaiá Garcia. Op. cit., 2008, p. 513.

${ }^{167}$ Ibidem, p. 513.
} 
Vendo a filha privada dos recursos financeiros para cobrir os termos de um contrato conjugal, Garcia se "sacrifica" para pagar-lhe os estudos e dar-lhe as mesmas condições de vida das outras "iaiás". Nesse esforço, coadunam, naturalmente, o carinho paterno e o interesse pessoal de ver a filha prosperar socialmente; e, efetivamente, no final, Iaiá consegue realizar todos os seus desejos. Perspicaz, ela sugere ao pai o sonho de ser professora de piano e, com isso, Garcia se estimula a comprar o instrumento como uma possibilidade de vê-la assegurada por meio de uma profissão, caso ela não consiga o respaldo econômico de um matrimônio.

Portanto, do plano simbólico do objeto, pode-se dizer que ele reflete o desejo da menina pela posse de um bem superior às suas condições. Nesse sentido, sua tristeza ao comparar os móveis da casa ao presente é tão súbita quanto rápida, porque a sua vontade, a satisfação pessoal, prevalece sobre a dificuldade familiar. O caráter da criança se desenha por meio de uma tendência à astúcia, como também, indica que sua educação está voltada para a satisfação dos seus caprichos, evidenciando o culto de um comportamento individualizado. Essa maneira de proceder de Iaiá, disposta a conquistar o seu desejo, ganha mais relevo a partir do momento em que ela começa a frequentar a casa da matriarca Gomes.

[...] Iaiá entrara na intimidade da casa, menos ainda pelo que podia haver - e havia - de simpático e atraente em sua pessoa, do que pelo esforço próprio. A sagacidade da menina era a sua qualidade mestra: assim viu depressa o que era menos agradável, para evitá-lo, e o que era mais, para cumpri-lo. Essa qualidade ensinava-lhe a sintaxe da vida, quando outras ainda não passam do abecedário, onde morrem muita vez. Obtida a chave do caráter de Valéria, Iaiá abriu a porta sem grande esforço. 168

A personalidade atraente de Lina Garcia, que o narrador já havia anunciado desde o início da caracterização da personagem, retorna neste excerto como maneira de explicitar um traço natural da menina e que lhe rende um artifício na conquista das pessoas a sua volta. Articulando a natural alegria, a espontaneidade de ser, ela conquista a amizade de Valéria e assume um lugar na intimidade da casa da rica viúva, sem despender grande esforço. Nesse sentido, ao desejar fazer parte da vida da matriarca, pode-se inferir que a garota esteja fisgada pelo poder e prestígio de Valéria. De todo modo, a força preponderante de Iaiá na conquista da amizade de Valéria se fundamenta na esperteza da garota em mostrar-se simpática aos olhos da outra.

\footnotetext{
${ }^{168}$ Ibidem, p. 541-542.
} 
Essa postura de Lina Garcia evidencia-se no enredo a partir do uso da sua "sagacidade" ao desejar fazer parte de um círculo social do qual sua posição a põe à margem. Como afirma o narrador, a perspicácia da menina "ensinava-lhe a sintaxe da vida" e, no percurso do seu aprendizado do convívio em sociedade, ela adere rapidamente a subordinação à protetora na finalidade de não lhe desagradar, no que "[...] outras ainda não passam do abecedário, onde morrem muita vez." Então, enquanto Estela manifesta seu temperamento austero na relação de dependência à matriarca Gomes, Iaiá entra na intimidade da viúva adaptando-se facilmente ao convívio da sua casa e, nesse momento, à sua desenvoltura de personalidade vem somar o aprendizado das regras do favor e cooptação.

Na casa dos Gomes, a filha de Garcia se aproxima e deixa-se envolver pela dependência e, por meio da sua perspicácia, compreende os hábitos da viúva Gomes, seu gosto por ver em Estela a obediência sem ademanes de servilidade, comportando-se como uma "amiga da matriarca". A relação de dependência entre Estela e Valéria e a proteção desta para com a sua "agregada" servem à Iaiá como meio de aprendizado sobre como agir diante da viúva. Com a descoberta dessa estrutura forjada na disparidade de poder e de posse, ao compreender a moral clientelista, a adolescente não precisou de mais nada para ter a "chave" necessária para conquistar a amizade da matriarca. Aprendidas as regras do sistema do favor e da cooptação, ela torna-se, também, uma agregada da viúva e, por consequência, ela estreita o laço de amizade com Estela. A partir disso, o narrador passa a trabalhar a personalidade da adolescente em relação a sua nova amiga.

[Na intimidade da casa de Valéria], a presença de Estela tornou ainda mais aprazíveis à mocinha aquelas visitas, e, dentro de pouco tempo, era a afeição de Estela que mais lhe ocupava o coração.

A lei dos contrastes tinha ligado essas duas criaturas, porque tão petulante e juvenil era a filha de Luís Garcia, como refletida e plácida a filha do sr. Antunes. Uma ia para o futuro, enquanto a outra vinha já do passado; $[\ldots]^{169}$

Por meio dessa divisão temporal entre passado e futuro, o narrador recupera o reconhecimento das "qualidades morais" de Estela como "caducas" por Luís Garcia e orienta a compreensão do caráter de Iaiá Garcia. Assim, a primeira liga-se ao passado da relações sociais cujo valor pessoal e a dignidade do indivíduo põem-se como meio de reconhecimento do sujeito na sociedade patriarcal. Já a segunda, indo para o futuro,

${ }^{169}$ Ibidem, p. 542, grifo nosso. 
representa os novos tempos, a flexibilização do modo de vida patriarcal, pois sua "ação social" é movida pela argúcia, calculada e "racionalmente orientada". ${ }^{170} \mathrm{O}$ seu propósito pessoal, o fim do seu modo de agir visando um objetivo racional, fomenta uma conduta que corresponde ao comportamento próprio das sociedades burguesas.

Afirmando essa dicotomia entre passado e futuro, o narrador direciona e reforça a compreensão do temperamento das duas mulheres: Estela, a jovem que preza absolutamente por sua dignidade diante das relações de favor; e Iaiá, que tem a vivacidade de espírito de quem pretende alçar vôos mais altos, movida pela perspicácia, mecanismo que resulta no seu alinhamento ao poder da proprietária. Logo, a aproximação entre a jovem Estela e a adolescente Iaiá Garcia na casa de Valéria lança luz sobre a diferença de postura e inflexão moral de ambas as personagens, e o enredo que se desenvolvia sobre o rígido caráter moral de Estela, encoberto pela força do sistema de cooptação e favor, cede espaço à personalidade simpática e, ao mesmo tempo, astuta de Iaiá Garcia.

No primeiro encontro dessas personalidades discrepantes na casa de Valéria "houve um instante de hesitação entre as duas;" ${ }^{171}$ como reflexo dessa diferença de temperamento, sobretudo na adolescente que se sente "acanhada" ao ver a figura severa de Estela. No entanto, na mesma medida em que abstrai as dificuldades financeiras da sua casa ao confrontá-las com o piano, o acanhamento de Iaiá não dura um instante e logo se torna em "afeição imediata". ${ }^{172}$ A adolescente de raciocínio rápido, logo vê a "gravidade" de Estela como um elemento de fácil transposição. "Iaiá sentia instintivamente que havia em Estela alguma coisa que sarar ou consolar." ${ }^{173}$ Assim, a menina compreende que o ar severo da filha de Antunes corresponde apenas a uma postura social. Em outras palavras, Lina supõe conseguir vencer a rigidez da amiga por meio da habitual simpatia que já lhe houvera aberto as portas da casa de Valéria. Já Estela deixa-se envolver pelo comportamento naturalmente alegre, ondulante e atraente da nova amiga, porque "[...] tinha necessidade de temperar a sua atmosfera moral com um raio da adolescência da outra [...]"174 A juventude radiante e sincera de Iaiá, que destoa, por exemplo, do

\footnotetext{
${ }^{170}$ Cf. WEBER, Max. Economia e sociedade: fundamentos da sociologia compreensiva. Tradução Regis Barbosa e Karen Elsabe Barbosa. 5 ed. Brasília: UnB, 2009.

${ }_{172}^{171}$ MACHADO DE ASSIS. Iaiá Garcia. Op. cit., 2008, p. 541.

${ }^{172}$ Ibidem, p. 541.

${ }^{173}$ Ibidem, p. 542.

${ }^{174}$ Ibidem, p. 542.
} 
comportamento dissimulado de Valéria, encontra um espaço vago onde ecoar na personalidade estóica de Estela.

Por meio desse encontro, o narrador introduz um novo elemento no "drama" romanesco, o casamento de Estela, que permite, no decorrer da história, acompanhar o processo de amadurecimento e arrematar o perfil da filha de Garcia. Assim, um dia a adolescente encontra a amiga Estela contemplando um antigo álbum de fotos de Valéria, no qual podem ser vistos em cada uma das páginas Jorge Gomes e Luís Garcia. “A moça estava tão embebida, que só deu pela presença de Iaiá quando esta parou do outro lado da mesa e inclinou os olhos para o álbum. Estela teve um pequeno sobressalto, mas dominou-se logo." 175 Tentando disfarçar o olhar contemplativo sobre a foto de Jorge, ela se recompõe rapidamente e, em tempo, dirige-se a Iaiá dizendo ter Garcia "uma fisionomia de bom coração" 176 , comentário recebido com naturalidade pela menina, "que adorava o pai." "177 Entretanto, Estela tenta disfarçar o constrangimento de ter sido flagrada admirando a foto de Jorge, e "depressa fecha o álbum com a mão trêmula", "178, mas Iaiá apenas consegue ter olhos para a foto paterna. $\mathrm{O}$ amor filial da garota não permite que ela perceba o sobressalto da amiga, quanto menos dê alguma importância à foto de Jorge, pois, sua destreza de raciocínio segue por outro caminho. Após ouvir o comentário de Estela, Iaiá chega à resolução de ver o pai casado com a amiga, comunicando imediatamente a ideia: “- A senhora podia casar-se com papai - disse a menina depois de olhar algum tempo a outra." ${ }^{\prime 19}$

Lina Garcia tinha igual afeição pelo pai e por Estela e, ao ouvir da amiga que ele tinha "bom coração", expressão que conduz ao entendimento do caráter afetivo, Iaiá, na sua agudez de raciocínio, conjectura a possibilidade de consumação dessa união. A expressão usada por Estela cria-lhe a esperança de ver nascer a relação afetiva entre a amiga e o pai. Nesse sentido, Iaiá trabalha no que viria a ser o casamento de seu pai e Estela, acreditando nessa futura união possivelmente sentimental. A menina ainda não compreende que o matrimônio pode ser pautado apenas na conveniência dos membros da relação, ou também, um ato manipulado pelo interesse da autoridade parental.

\footnotetext{
${ }^{175}$ Ibidem, p. 542.

${ }^{176}$ Ibidem, p. 542.

${ }^{177}$ Ibidem, p. 542.

${ }^{178}$ Ibidem, p. 542.

${ }^{179}$ Ibidem, p. 542.
} 
O resto foi obra de Iaiá, obra dividida em duas partes, uma voluntária, outra inconsciente. Voluntária, porque também a menina, no silêncio laborioso de seu cérebro, construíra o projeto de os unir, e o dissera mais de uma vez a um e a outro. Inconsciente, porque o amor que a ligava a Estela foi a mais poderosa força que modificou o pai. Era uma afeição intensa a dessas duas criaturas; ao passo que Iaiá dava a Estela uma porção de ternura de filha, Estela achava no amor da menina uma antecipação dos prazeres da maternidade. $^{180}$

Nesse sentido, somente após alguns da união entre seu pai e Estela, período que coincide com o final da Guerra do Paraguai e a volta de Jorge Gomes ao Rio ao Janeiro, Iaiá enxerga que o casamento não passou de um ato de conveniência. Essa percepção da jovem permite ao narrador marcar um novo traço no perfil da personagem, frisando a sua entrada na vida adulta a partir da cena em que Luís Garcia decide liquidar os papéis antigos do seu escritório. Revolvendo as gavetas da "secretária", Garcia depara-se com uma carta enviada por Jorge no período de Guerra, lastimando a distância e indiferença da mulher amada. Após reler a missiva, ele passa-a às mãos da esposa. Estela, ao ler as primeiras linhas, terrifica-se, porque seu marido poderia conhecer-lhe o passado com o herdeiro da família Gomes. No entanto, submerso nos papéis a serem deitados no lixo, Garcia não percebe o desconserto da esposa e, sorrindo, conclui: “- Que poesia, hem!" 181 Já a perspicaz adolescente, que a tudo assiste com atenção, não precisou mais que o comentário paterno para compreender a tensão da madrasta. "Iaiá olhou [Estela] a princípio com curiosidade, depois com espanto, até que os olhos luziram de sagacidade e penetração. O estilete que eles escondiam desdobrou a ponta aguda e fina, e estendeuse até ir ao fundo da consciência de Estela."182

Ao presenciar o abatimento da madrasta lendo a carta de Jorge, Iaiá adivinha todo o passado amoroso entre os dois, "[...] mas adivinhou demais [assegura o narrador]. Galgou a realidade até cair no possível. Supôs um vínculo anterior ao casamento, roto contra a vontade de ambos, talvez persistente, mau grado aos tempos e às coisas." ${ }^{183} \mathrm{Na}$ mente da filha de Garcia, o amor de Jorge e Estela era um sentimento ainda vivo, forte e superior à relação de Estela e Garcia. Para a adolescente, a madrasta tinha uma paixão supostamente adúltera, uma ligação de forte apelo sentimental com Jorge e por isso reagira nervosamente ao ler a carta de amor guardada por Luís Garcia. Na ponderação

\footnotetext{
${ }^{180}$ Ibidem, p. 545.

${ }^{181}$ Ibidem, p. 566.

${ }^{182}$ Ibidem, p. 566-567.

${ }^{183}$ Ibidem, p. 567.
} 
de Iaiá, esse amor, talvez ainda presente, representa uma ameaça a seu pai e contra a felicidade familiar. A força dessa descoberta termina por findar os gestos travessos e a inocência adolescente. A menina mimada de outrora é arrebatada do seu mundo infantil ao se defrontar com essa descoberta, porque "[...] não conhecia as vicissitudes do coração. Jardim fechado, como a esposa do Cântico, viu subitamente rasgar-se-lhe uma porta [...]" ${ }^{\prime 184}$ Outra vez irônico, o narrador decalca o discurso de amor à Sulamites, por seu noivo, em Cântico dos $\operatorname{Cânticos}^{185}$, a Iaiá, que somente conhece a afeição paterna. A porta que se lhe rasga, então, não é um convite para viver a ventura amorosa, mas a compreensão do casamento como uma escolha racional, não afetiva e na qual ela esperava ver o pai.

Temendo a desventura paterna, a descoberta causa-lhe a desordem pessoal. Mesmo tendo compreendido a relação entre a carta de Jorge e a reação de Estela, Iaiá busca um subterfúgio que lhe garanta alguma segurança em relação ao sentimento da madrasta pelo pai e, recordando a figura pálida e ascética de Estela, por um instante a consciência fez "as pazes com a malícia." 186 Incrédula na sua dedução do amor da madrasta por outro homem, Iaiá recorre ao semblante severo de Estela, como se quisesse, em uma luta íntima, desacreditar no pensamento mal que lhe brotara na mente, porque, ao aceitálo "os primeiros germes da ciência do mal" "187 penetravam-lhe na alma e corrompiamlhe a crença do amor como um sentimento natural. Entretanto, a "sagacidade" da adolescente vence o apelo à imagem da amiga. Iaiá compreende a equação sentimental do universo adulto e esquemático, no qual o casamento não passa de um arranjo social, sem a valorização sentimental despida de conveniência ou interesse. Assim, se "não conhecia a hipocrisia, [...] acabava de suspeitá-la; começava talvez a aprendê-la."

A despeito da pouca experiência de vida de Iaiá, a partir de sua luta íntima compreende o antigo envolvimento da madrasta com o filho de Valéria. Assim, por meio da descoberta desse vínculo afetivo de Estela, Iaiá aprende a "hipocrisia" da vida adulta e

\footnotetext{
${ }^{184}$ Ibidem, p. 567.

185 "A alusão ao Cântico dos Cânticos (4:12), cujo tema é o amor entre homem e mulher, que trocam juras de amor." ROMANCES EM HIPERTEXTO: Iaiá Garcia: Banco de dados preparado por Marta de Senna. In: FUNDAÇÃO CASA DE RUI BARBOSA. Machado de Assis.net: no ar desde 2007. Disponível em: <http://www.machadodeassis.net/hiperTx_romances/obras/iaiagarcia.htm> Acesso em: 9 Jan. 2011.

${ }^{186}$ MACHADO DE ASSIS. Iaiá Garcia. Op. cit., 2008, p. 567.

${ }^{187}$ Ibidem, p. 567.

${ }^{188}$ Ibidem, p. 568.
} 
“a criança acabara; principiara a mulher."189 A partir de então, a sua perspicácia garante-lhe a compreensão de que, em sociedade, os indivíduos ponderam emoções em favor da conveniência pessoal, minando, com isso, a expressão espontânea e sincera de sentimentos. Dessa compreensão social, do amadurecimento de Lina, nasce uma mulher temerosa e decidida a evitar o esfacelamento familiar. Imbuída desse ânimo, a filha de Garcia assume uma personalidade dissimulada à qual vem somar força à sagacidade da adolescente, ensejando uma postura feminina madura e autocentrada.

A primeira evidência desse novo aprendizado aparece pouco tempo depois do episódio da carta de Jorge. Refugiada em seu quarto, onde chora pelo pai, Lina é surpreendida pela madrasta que, desconhecendo a razão da enteada, supõe vê-la chorar pelo amigo da família, Procópio Dias. À sugestão de Estela, Iaiá “afivela a máscara da tranquilidade" 190 , confirmando a sua plena adaptação ao recurso do fingimento social. Para destituir a madrasta de uma possível ideia de um vínculo com o negociante Procópio Dias, logo diz: "Pois bem, vou confiar-lhe uma coisa... não... suponha... é melhor supor... tenho vergonha de dizer a verdade. Suponha que tive um amor de colégio..." ${ }^{191}$ A frase reticente da jovem evidencia a construção momentânea e ainda desajeitada do mecanismo da dissimulação, mas o seu argumento mostra-se claramente contrário à inferência de Estela sobre o amor da enteada pelo quinquagenário negociante. Como não se sente atraída por ele, Iaiá rejeita prontamente o comentário da madrasta a fim evitar o desdobramento dessa dedução em um matrimônio orquestrado pelos pais e por isso afirma ter "um amor de colégio".

No entanto, após expressar esse desinteresse por Procópio Dias, Lina Garcia se surpreende com o comentário de Estela para quem o "amor era uma simples escolha da razão". ${ }^{192}$ Iaiá recebe outro golpe, o mesmo de quando supôs todo o passado de sua madrasta com Jorge. A filha de Antunes nega seus sentimento tanto pelo tenentecoronel como por Luís Garcia, assumindo que seu casamento foi uma mera escolha de propósitos racionais. “[...] Iaiá empalideceu. Ao último gesto de Estela respondeu com um sorriso forçado e sem cor." ${ }^{193}$ Nesse momento, a frieza e a sinceridade da madrasta

\footnotetext{
${ }^{189}$ Ibidem, p. 567.

${ }^{190}$ Ibidem, p. 569.

${ }^{191}$ Ibidem, p. 569.

192 Ibidem, p. 569.

${ }^{193}$ Ibidem, p. 570.
} 
arrebatam-lhe qualquer esperança em um relacionamento firmado pelo sentimento. Para além da sua suposição inicial, quando inferiu a antiga relação amorosa entre Estela e Jorge, essa fala soa a Iaiá como uma sentença dura e final sobre as relações matrimoniais.

Doravante, Iaiá tem a pretensão particular de vencer o amor de Estela e Jorge e, na presença de Jorge, ela pronuncia frases "mais longas” e "deduzidas”, “[...] [indo] até o fim do pensamento, sem as interrupções e saltos do costume." ${ }^{194}$ Iaiá assume a sociabilidade de salão onde a mulher age com o decoro necessário para manter as aparências, o status familiar, dissimulando o repúdio pela figura e presença de Jorge em sua casa, recebendo-o cordialmente. "Não vinha alegre decerto; serena, sim, daquela serenidade com que o caçador do sertão se dispõe a encarar a onça."195 Munida desse autocontrole, Iaiá caminha em direção ao futuro das relações sociais mediadas pelo comportamento enluvado da sala de estar. A menina lépida cede lugar à mulher que, acompanhando com os olhos as conversas, as relações travadas e as posturas assumidas dentro do seu lar, transforma-se em uma figura centrada, pronta a enfrentar as adversidades da vida adulta. Ela, então, usará de estratagemas de sedução e malícia para por em curso a atração de Jorge Gomes e, a princípio, desvendar-lhe as intenções em relação a Estela.

Nesse propósito, Iaiá começa a acompanhar de perto as visitas do tenente-coronel a Luís Garcia. Logo no primeiro encontro, Lina “[...] sentou-se ao pé dos dois para vê-los jogar; fincou os cotovelos na mesa e encostou o queixo nas mãos; queria aprender, dizia ela, em três semanas." ${ }^{196}$ A sua vontade de aprender um jogo com inúmeros lances e estratégias, em pouco tempo, metaforiza a intenção da menina em busca de um artifício capaz de atrair Jorge para si. Como afirma Luís Garcia, "Iaiá possuía [...] vista pronta e paciência beneditina; qualidades preciosas na vida, que também é um xadrez, com seus problemas e partidas [...]"197 Essa comparação entre o jogo e a vida, subtraída pelo narrador da fala de Garcia, evidencia a astúcia de Iaiá ao investir sobre a presença de Jorge na sua casa. Apesar da petulância em querer aprender regras complexas em pouco

\footnotetext{
${ }^{194}$ Ibidem, p. 570.

195 Ibidem, p. 570.

${ }^{196}$ Ibidem, p. 557.

${ }^{197}$ Ibidem, p. 577.
} 
tempo, ela já tem perspicácia e paciência, "qualidades preciosas” para jogar o xadrez e "as partidas" da vida adulta.

Agindo habilmente como uma jogadora, Iaiá decide ser parte ativa nas relações sociais da família. Metaforicamente, ao aprender as regras do xadrez ela pretende adquirir condições de vencer Jorge, seu adversário na manutenção da felicidade paterna. Esse comportamento incisivo ao posicionar-se em relação à vida familiar desacredita a corrente discursiva patriarcal do meados do século XIX, a qual sustentava o estereótipo da conduta ingênua, frágil e submissa como predicativos comuns ao gênero feminino. ${ }^{198}$ Do ponto de vista do adversário, essa caracterização da jovem avessa ao modelo da donzela ingênua surte um efeito de encantamento. A incompreensão do comportamento imprevisto de Iaiá despertam a atenção de Jorge. Observando-a, ele nota que "uma ou duas vezes, Iaiá lhe pareceu singularmente áspera, sem motivo, nem duração. Esses assomos, porém, eram logo compensados por uma afabilidade, que parecia mais viva, e mais ruidosa, talvez um pouco importuna." 199 O tratamento abrupto com o qual ela se dirige a ele, alternando rispidez e simpatia, amuo e alegria, dão-lhe a indicação de um temperamento caprichoso e multifacetado. A percepção da conduta camaleônica de Iaiá aos poucos instiga-lhe a mente e, logo, prende-lhe a atenção. Ao dissimular o seu comportamento de forma inteligente, Lina cria, na percepção de Jorge, o mistério ecoado da personalidade feminina, o "véu em que [Iaiá] trazia envolto o pensamento"200 e que provoca a fértil imaginação do tenente-coronel.

Apesar de ter o seu interesse despertado pelo caráter da moça, Jorge tem um acordo de cavalheiros com Procópio Dias que, fazendo uma viagem à Argentina, pede ao amigo para tomar conta de Lina Garcia. A princípio, essa designação de Jorge se converte em transtorno a Iaiá, porque, sabendo da atribuição do tenente-coronel, ela compreende, outra vez, a sugestão de um matrimônio com Procópio Dias posta em seu caminho. A simples ideia de lhe ofertarem esta união lhe causa repulsa. Assim, mesmo com Jorge, com quem principia uma conversa velada pelo interesse de sondar-lhe seus sentimentos sobre Estela, não seria diferente; pelo contrário, ela se torna rude e nervosa, dizendo-lhe que ele se fazia "ridículo" ao prestar-se a ajudar Procópio Dias.

\footnotetext{
${ }^{198}$ Cf. DUBY, Georges; PERROT, Michelle (Dir.). Op. cit.

${ }^{199}$ MACHADO DE ASSIS. Iaiá Garcia. Op. cit., 2008, p. 578.

${ }^{200}$ Ibidem, p. 589.
} 
Jorge enfiou um pouco; mas a um homem de sociedade, Iaiá não parecia de força a fazer perder o equilíbrio. Sorriu levemente, e retorquiu sem azedume:

- Não é ridículo ser afetuoso; eu cuidava responder à linguagem de seu coração.

- Supunha que a ausência de Procópio Dias me deixava saudades...

- Supunha.

- Que tem o senhor com isso?

A resposta de Jorge foi um simples gesto negativo. Contudo, não pôde zangar-se, porque sentia tremer o braço da moça, e olhando de esguelha para ela via-a pálida e com os olhos no chão. Se a palidez e o tremor eram de cólera, não chegou a sabê-lo; mas provavelmente não era outra coisa, porque ao cabo de três a quatro minutos, Iaiá ergueu os olhos e estendeu-lhe a mão, dizendo:

- Façamos as pazes.

- Nunca estivemos em guerra, acho eu.

- Talvez em véspera de guerra.

- Não por culpa minha...

- Nem minha - acudiu a moça. [...] $]^{201}$

Debutante da vida adulta, embora se irrite com Jorge, ela se esforça em omitir o seu dissabor de estreitar relações com ele, dando "uma risadinha seca e forçada". Logo declara o armistício entre ambos. Para Jorge, a jovem representa não mais que uma atração desprovida de sentimentos ou desejos pungentes. Ele se sente atraído justamente por essa oscilação no comportamento da filha de Garcia, e ela passa a ocupar a sua mente como um epigrama o qual ele não se cansa em querer entender. $\mathrm{O}$ misterioso comportamento da jovem avança sobre a mente imaginativa de Jorge, e estende-se progressivamente ao longo do contato entre eles. A paz requerida por Lina Garcia vem acompanhada de um falar mais doce, com os olhos baixos, indicadores da estratégia pessoal de conquista.

Atiçado pela faceirice da moça, ele aceita o armistício de uma guerra que nunca conhecera e, como consequência dessa trégua, Jorge se predispõe a jogar uma partida de xadrez na casa de sua nova "amiga". A sós e de frente para o tabuleiro, Iaiá se sente à vontade e disposta a executar manobras mais ousadas, mas que não se prestavam à lógica do xadrez. Assim, quando Jorge diz ser a vez dela na partida, "Iaiá não obedeceu ao convite. Olhava para ele, com ar inquieto. - Dá-me sua palavra de honra de que me não negará o que lhe vou perguntar? - disse ela ao cabo de alguns instantes de silêncio. ${ }^{202}$ Com esse comportamento, Iaiá cria um clima de relativo suspense ao pedir a palavra de honra de Jorge em nome do segredo que pretende lhe contar. Como se possuísse uma confidência, uma revelação impactante, amplia o mistério da sua figura e

\footnotetext{
${ }^{201}$ Ibidem, p. 579.

${ }^{202}$ Ibidem, p. 580.
} 
provoca ainda mais a curiosidade de Jorge. Nesse sentido, o narrador sugere que a filha de Garcia suspeite que Jorge seja um homem de mente fantasiosa, porque, desde então, ela trabalha na linha do suspense para chamar a sua atenção.

Nesse jogo de sedução, Iaiá confidencia seu amor por Procópio Dias a Jorge, que reage efusivamente: "Jorge estendeu-lhe a mão: - Magnífico - disse ele alegre -; não é preciso mais. Uma vez que se amam, virão naturalmente a..." ${ }^{203}$ Antes de concluir a sentença, Jorge foi interrompido por Iaiá que abruptamente se levantara ao inferir, pela lógica do confidente, a palavra casamento. Embora não pretenda se ligar a Procópio Dias, ela se vale da intenção deste homem em esposá-la, criando, com isso, uma motivação para se confidenciar a Jorge. Cria então um vínculo de intimidade com o tenente-coronel. Atraindo-o para perto de si, Iaiá pode instigar a mente dele por meio de um jogo de negação e aproximação. Ela pede a Jorge para ser seu confidente e, no entanto, quando lhe revela o segredo, mostra-se arredia à solução por ele proposta.

Metaforizando a luta íntima da mulher a fim de domar a sua emoção, o narrador informa: “[...] o tacão de Iaiá [...] feria o ladrilho do chão, com um movimento precipitado e nervoso. Durou isso cinco minutos". ${ }^{204}$ A jovem voluntariosa organiza a sua mente com rapidez e admite ter tido uma reação "estouvada" ao comentário de Jorge e volta a comportar-se com serenidade e brandura. Esse jogo traçado de maneira sinuosa, no qual ela se demonstra dúbia, novamente acende o interesse de Jorge que não se atreve a questioná-la, temendo a sua reação, mas permanece na mesa para mais uma partida.

Essa maneira de agir de Jorge, curioso, mas sem ceder de vez ao encanto que a jovem lhe desperta, aos poucos, para Iaiá torna-se um elemento irritante. Voluntariosa, pode-se dizer que ela entende o comportamento do adversário como "pirraça", compreendendose, por meio desse substantivo, a definição de Stendhal sobre um dos meios para se chegar ao amor. Para o crítico francês, a "pirraça" surge como uma estratégia social de conquista amorosa cujo procedimento consiste em provocar o orgulho da pessoa amada, insinuando-lhe o interesse afetivo para, logo em seguida, dissimular tal interesse. Nesse jogo, o sujeito do foco amoroso sentir-se-á provocado na sua vaidade por meio da

\footnotetext{
${ }^{203}$ Ibidem, p. 581.

${ }^{204}$ Ibidem, p. 581.
} 
suposta rejeição do seu admirador, que, com isso, alcançará a admiração da pessoa amada.

\begin{abstract}
[Para Stendhal] a pirraça triunfa no amor-gosto, constituindo seu destino. É a experiência pela qual melhor diferenciamos o amor-gosto do amor-paixão. Uma velha máxima de guerra ensinada aos jovens quando chegam ao regimento diz que, se temos duas irmãs e queremos ser amados por uma delas, devemos cortejar a outra. Junto à maior parte das espanholas jovens, e que fazem amor, se você quiser ser amado, basta demonstrar boa-fé e com modéstia que não tem nada no coração pela dona da casa. [...] É a maneira mais perigosa de atacar o amor-paixão. ${ }^{205}$
\end{abstract}

Apesar de não armar uma estratégia para conquistar o amor de Iaiá, ao aceitar fazer parte do jogo de xadrez com a garota e, sobretudo, insistir na relação dela com Procópio Dias, indiretamente, Jorge aciona esse mecanismo afetivo proposto da teoria stendhaliana, pois Iaiá compreende essa intervenção a favor de Procópio como uma provocação. Afinal, Jorge parece negar o seu fascínio pelo comportamento de Iaiá ao se fazer de desinteressado pelo jogo de sedução que ela elabora, confirmando o seu amor por Estela na mentalidade de Iaiá. Assim, a energia empenhada na tarefa de seduzir o jovem ampliava a necessidade de conquistá-lo, como se ele, mirando a Estela, despertasse a paixão de Iaiá. Então, o estouvamento da jovem em relação à afronta de Jorge sinaliza para início da construção sentimental pelo seu adversário.

O jogo de xadrez propriamente falando passa a ser apenas o pretexto para que ambos possam permanecer mais tempo juntos com a finalidade única de vencer a máscara social imposta por um e outro no jogo das aparências como descreve o narrador: "Entre eles o xadrez não podia oferecer interesse, mas dado que o pudesse, não seria naquela ocasião. Um e outro estavam distraídos e preocupados. A primeira partida foi concluída em pouco tempo, quase sem cálculo." ${ }^{206} \mathrm{Na}$ verdade, o xadrez mascara o interesse de Jorge em descobrir a mulher escondida por trás daquela sinuosidade de comportamento envolvente, como também, o objetivo de Iaiá em descobrir o sentimento do seu adversário em relação à madrasta. Cada qual tem seu objetivo específico e não jogam em "boa paz”. Ambos blefam em relação às suas intenções, mas, por fim, representam bem como atores o jogo social cortês. Porém, essa aproximação leva-os ao amadurecimento do sentimento amoroso e na segunda partida do xadrez, o clima já é de mútua admiração.

\footnotetext{
205 STENDHAL. Op. cit., p. 107, grifo do autor.

${ }^{206}$ MACHADO DE ASSIS. Iaiá Garcia. Op. cit., p. 581, grifo nosso.
} 
[Iaiá] Quando falava, era moderada e dócil. Essa alternativa e contraste de maneiras interessava naquele momento o espírito de Jorge. Que espécie de mulher fosse, imperiosa como uma matrona, travessa como uma criança, incoerente e enigmática, era coisa que ele não podia em tão pouco tempo descobrir; mas o enigma aguçava-lhe a atenção. Enquanto ela tinha os olhos no tabuleiro, Jorge buscava ler-lhe a alma na fronte lisa e cândida; mas não via a alma, via só uns fiapos castanhos de cabelo, que lhe caíam sobre a testa e esvoaçavam levemente ao sopro da aragem que entrava pela janela, e lhe davam um ar de puerícia. A boca fina e pensativa corrigia aquela expressão da cabeça; era a primeira vez que ele lhe descobria um forte indício de energia e tenacidade.

Quando era a vez de Jorge, Iaiá afastava o busto, reclinava-se no espaldar da cadeira e ficava a olhar para ele, como ele havia olhado para ela. Mas nesse olhar não cintilava curiosidade; era uma luz velada e baça, como alheia ao mundo exterior. Encontravam-se assim os olhos de um e de outro, e a partida continuava, até chegar ao fim sem novo incidente. ${ }^{207}$

Sem palavras, apenas com os olhares, a concentração e a paciência exigidas no jogo de xadrez levam Iaiá e Jorge a abstraírem-se um do outro. Como consequência do caráter misterioso da moça, Jorge se sente inebriado e apenas consegue contemplá-la fisicamente. O cabelo caído sobre o rosto, a descrição dos lábios, o movimento da cabeça, insinuam a pulsão sexual descrita de maneira velada nas referências corporais da jovem. Jorge enxerga-a como mulher, por meio do desejo físico, do mesmo modo como desenvolvera o seu amor por Estela, iniciado a partir da pulsão sensual sobre a mulher de estrato inferior. Nesse propósito, John Gledson ${ }^{208}$, analisando a sexualidade nos romances Casa Velha e Dom Casmurro, sustenta a teoria de que Machado de Assis, para além da teoria naturalista de hereditariedade, vê na pulsão sexual um instrumento das relações humanas.

Os relacionamentos sexuais são sempre vistos como um reflexo de outros, aos quais são análogos, sem desempenhar, eles mesmos, um papel fundamental causal. $\mathrm{O}$ que se transmite aqui de uma geração para a seguinte não é, por assim dizer, material genético, mas uma relação de poder e opressão. Em última instância, o que talvez seja notável é que Machado sentisse que a intensidade dessa repressão só podia ser transmitida através da referência a um evento tão extraordinário. ${ }^{209}$

Iaiá, por sua vez, apesar de também se deter sobre a figura do filho de Valéria, não o focaliza tendo em vista a mera compleição masculina. O olhar da moça, sem curiosidade, encobre-se de uma "luz velada e baça" por meio da qual o narrador direciona a reflexão de Iaiá sobre aquela situação, como se, presenciando o interesse

\footnotetext{
${ }^{207}$ Ibidem, p. 582.

${ }^{208}$ GLEDSON, John. Machado de Assis e Graciliano Ramos: especulações sobre sexo e sexualidade. In: Por um novo Machado de Assis: ensaios. Tradução Frederico Dentello. São Paulo: Companhia Das Letras. 2006. cap. 11, p. 312-334.

${ }^{209}$ Ibidem, p. 325, grifo nosso.
} 
crescente do tenente-coronel por ela, algum pensamento ou sentimento a despertasse para uma nova realidade. "Alheia ao mundo exterior", isto é, abstraindo a sua motivação em conhecer as intenções de Jorge sobre Estela, Iaiá se deixa envolver pelo clima de sedução, iniciando seu sentimento amoroso por Jorge. Nesse sentido, ela deriva, da relação entre a madrasta e o pai, o aprendizado do matrimônio por conveniência e, na partida do jogo social, ela desperta para atração sentimental.

O processo de "cristalização" 210 amorosa, antes dirigido a Estela, parece refazer-se em Jorge e dar a primeira florada em Lina Garcia, pois ambos tornam-se admiradores mútuos. A jovem, que até então não conhecia o amor de um homem, desperta para um sentimento novo. O anterior objetivo de Iaiá de salvar o relacionamento paterno, começa a ter definições mais tênues, pois o seu repúdio inicial ao contato com Jorge começa a minar. O antigo adversário passa a ser visto de maneira complacente. A afabilidade com a qual trata Jorge já não representa então apenas a face da mulher interessada em preservar a felicidade paterna, mas também o princípio do amor.

Essa paixão aflorada na jovem vai ao encontro da proposta do sentimento como "amorgosto" em Stendhal. Para o autor, esta categoria sentimental nasce a partir da vaidade dos pares amorosos, que sabem conduzir os ademanes sociais em função da conquista afetiva, isto é, relação íntima perpetuada pela manipulação e sedução do homem ou da mulher é o elemento fundamental desse estado amoroso. Nessas circunstâncias, a conquista do amante se faz por meio da dissimulação do comportamento social, no qual o interesse e a malícia contam como guias de direcionamento ao estado afetivo de modo a ser ele uma construção sociocultural.

Um homem de bom nascimento sabe de antemão todos os procedimentos que deve ter e encontrar nas diversas fases desse amor; nada tendo de paixão ou de imprevisto, não raro ele tem mais delicadeza do que o amor verdadeiro, pois tem sempre muito espírito; é uma fria e linda miniatura comparada a um quadro de Carraches, e, enquanto o amor-paixão arrebata-nos contra todos os nossos interesses, o amor-gosto sabe sempre se adaptar a eles. ${ }^{211}$

Da mesma maneira, partindo do repúdio inicial pela figura de Jorge, Iaiá passa a tratar o tenente-coronel com maneiras corteses, e logo eles passam a adotar um comportamento reciprocamente amável e sedutor, que permite ao narrador, em se tratando de Iaiá

\footnotetext{
${ }^{210}$ Cf. STENDHAL. Op. cit.

${ }^{211}$ Ibidem, p. 3-4.
} 
Garcia, apostar na teoria de que o amor pode resultar da convivência e da confluência entre interesse e sentimento. Afinal, ela se aproxima de Jorge para defender a felicidade paterna e, em seguida, deixando-se envolver pelo tenente-coronel, adota um comportamento caracterizado por um misto de interesse e dedicação. Assim, "Iaiá atirou-se ao xadrez com um ardor incompreensível, e dizendo-lhe Jorge que era preciso ler alguns tratados, ela pediu-lhe um, e porque ele só os tivesse em inglês, Iaiá pediu que lhe ensinasse inglês." 212 Se em princípio ela tenta atrair Jorge desempenhando uma postura misteriosa, após o jogo, o "ardor incompreensível" com o qual ela se dedica ao xadrez indica que ela pretende tê-lo definitivamente para si.

Essa compreensão do desejo de Iaiá é reforçada quando, uma noite, “[...] recolhida aos seus aposentos, a moça deu largas a dois sentimentos opostos. Entrou ali prostrada. Que estou eu fazendo? - disse ela apertando a cabeça entre os punhos." ${ }^{213}$ Em meio à confusão dos seus pensamentos, Iaiá abre a veneziana de seu quarto e vê "a noite clara e serena" 214 , na qual "[...] os milhões de estrelas pareciam rir dos milhões de angústias da terra. Duas delas despegaram-se e mergulharam na escuridão[...]”215. Iaiá logo pensa que seria ela a próxima a mergulhar ali também. "Uma voz parecia dizer-lhe: Prossegue a tua obra; sacrifica-te; salva a paz doméstica. [...] Quando abriu de novo os olhos, não foi para interrogar, mas para afirmar - para dizer à noite que naquele corpo franzino e tenro havia uma alma capaz de encravar a roda do destino."216

Como bem observa Ronaldes de Melo e Souza ${ }^{217}$, nesta cena de Iaiá Garcia, o narrador ironiza a vida de Iaiá quando "[...] manifesta na análise contrastiva do universo celestial e do reino humano"218 o conflito íntimo vivenciado pela jovem. Diante do olhar contemplativo de Lina, que roga ajuda ao céu, os bilhões de estrelas parecem rir de sua aflição, do seu empenho em nome do pai, desacreditado durante o sono. Nesse momento, o pensamento recôndito da jovem revela-se durante o sonho no qual uma mulher com mãos de ferro the empurra da beira de um abismo. "Pálida, com o olhar desvairado, a boca irônica, essa mulher sorria, de um sorriso triunfante e mau;

\footnotetext{
${ }^{212}$ MACHADO DE ASSIS. Iaiá Garcia. Op. cit., 2008, p. 583.

${ }^{213}$ Ibidem, p. 586.

${ }^{214}$ Ibidem, p. 586.

${ }^{215}$ Ibidem, p. 586.

${ }^{216}$ Ibidem, p. 586-587.

${ }^{217}$ Cf. SOUZA, Ronaldes de Melo e. Op. cit.

${ }^{218}$ Ibidem, p. 104.
} 
murmurava algumas frases truncadas que ela não entendia. Iaiá bradou-lhe em alta voz: - Dize-me que não me amas e eu te amarei como te amava!"219 Acordada pela madrasta, Iaiá tem um grande sobressalto e afasta-se imediatamente. Perturbada, ela teme pela revelação que poderia ter feito a Estela durante seu pesadelo. Talvez tivesse revelado, em sonho, seu intento de conquistar Jorge. No sonho, era sua madrasta, sua adversária no amor de Jorge, quem a atirava no abismo; poderia ter revelado também a sua descoberta do antigo amor entre Estela e Jorge, resumindo o seu drama, a angústia que lhe espreitava todos os dias.

\begin{abstract}
A justaposição da cena do sonho ao litígio dos dois sentimentos opostos intensifica o drama de caracteres em ação na interioridade anímica de Iaiá Garcia. [...] As pulsões subterrâneas, que se enraízam no subsolo da vida psíquica e se realizam no sonho, denunciam que os móveis recônditos do comportamento de Iaiá Garcia são acionados pelo desejo amoroso da posse exclusiva de Jorge. ${ }^{220}$
\end{abstract}

Iaiá traz para o campo da afetividade o interesse em se aproximar de Jorge, unindo as duas "naturezas humanas", o caráter da jovem torna-se mais complexo, porque ela coaduna, em um mesmo objeto, a motivação subjetiva da atração por Jorge e o racional, deliberado pela manutenção do casamento paterno. Com isso, ela chega a síntese declarada à Maria das Dores, sua ama de leite, que, supondo ser Jorge namorado da moça, deseja saber quando se casam: “- O dia não sei. - E depois de uma pausa: - Mas que se há de fazer é certo. Ou eu não sou quem sou." ${ }^{221}$. Estendendo a relação de interesse para o mundo afetivo, ela assume de vez um comportamento determinado e incisivo. Porém, por trás dessa atitude racional e resoluta, interligam-se e perpassam-se o interesse e o desejo e, dessa maneira, o narrador prossegue na descrição da personagem atravessada por distintas motivações.

\footnotetext{
A força da paixão é um dado nuclear na construção dessas personagens. Desprovidas de seu ímpeto e garra, decairiam à condição unilateral de tipos interesseiros. Pois elas não têm apenas interesses: têm desejos; e assim como o narrador não cairá no naturalismo grotesco das caricaturas de Aluísio, tampouco retomará o estereótipo ultra-romântico da donzela frágil e assexuada peculiar à geração literária que precedeu à [...] estréia de romancista [de Machado de Assis]. ${ }^{222}$
}

\footnotetext{
${ }^{219}$ MACHADO DE ASSIS. Iaiá Garcia. Op. cit., 2008, p. 587.

${ }^{220}$ SOUZA, Ronaldes de Melo e. Op. cit., p. 104.

${ }^{221}$ MACHADO DE ASSIS. Iaiá Garcia. Op. cit., 2008, p. 595.

${ }^{222}$ BOSI, Alfredo. Op. cit., p. 21.
} 
Apesar da disposição em fincar os seus cotovelos no tabuleiro do jogo social, a figura de Iaiá não representa o estereótipo da mulher fria e exclusivamente interesseira. Nela há sentimentos, desejos, pulsão pessoal que, muitas vezes, a fazem oscilar entre o temperamento puramente interesseiro, protegido pela máscara da compostura social, e os arroubos momentâneos, nos quais a confusão toma-lhe a mente e os atos. Dessa maneira, ela se lança com veemência aos seus projetos, evidenciando um caráter antitético à moral severa de Estela. Vencer no projeto afetivo ou social, torna-se um objetivo para a astuciosa Iaiá, no que a sua adaptação rápida ao aprendizado da estrutura de dependência serve-lhe de instrumento na renovação do seu comportamento, que a leva a um matrimônio cujo valor se baseia na confluência de interesse e desejo, ou seja, de razão e sentimento. 


\section{CONSIDERAÇÕES FINAIS}

A abordagem escolhida pelo narrador ao estruturar o romance Iaiá Garcia demonstra que ainda que mantenha a onisciência, o seu ponto de vista se mostra dúbio. Machado de Assis parece estar em busca de uma forma capaz de expressar múltiplos pontos de vista em conflito no jogo social. A despeito de seu julgamento de valor em alguns momentos da narrativa e da visível simpatia por uma personagem em relação à outra, ao final, o narrador consegue, por oposição, descrever a diferença de comportamentos ao longo do processo histórico, estabelecendo um panorama social da época na qual transcorre a história de Iaiá Garcia; uma sociedade patriarcal que lentamente se movimenta em direção da sociedade de classes.

Nesse contexto, a caracterização e a oposição das personagens, em especial de Estela e Iaiá Garcia, corroboram a compreensão da transição histórica por que passa o sistema social e econômico do Brasil oitocentista. Trabalhando a análise psicológica e os conflitos das personagens, o narrador evidencia o passado patriarcal e o futuro que tende a adaptar o ideário burguês ao quadro clientelista local. ${ }^{223}$ As motivações que determinam a escolha dessas duas mulheres por seus pares amorosos desvendam a lógica que rege a instituição do casamento na sociedade oitocentista: a "[...] concepção que têm os personagens machadianos do que sejam o amor e o casamento e, por outro lado, do que sejam eles diante dos delicados jogos de mari-vaudage que o homem e a mulher têm de representar para se poder chegar à união.",224

Ao tratar das razões que levam os indivíduos a se casar, Machado de Assis joga com três diferentes códigos matrimoniais: a escolha paterna, a escolha pessoal baseada na motivação afetiva e a escolha fundamentada nos interesses pessoais do casal. Confrontando um código ao outro, por meio da rede afetiva urdida entre Estela, Jorge e Iaiá Garcia, o narrador capta a atmosfera clientelista da época e discute a sua influência na vida íntima das personagens. Assim, Estela e Jorge deixam-se atrair um pelo outro, aparentemente, movidos pelo princípio sentimental, como já prescrevia o amor

${ }^{223}$ Cf. SCHWARZ, Roberto. Op. cit.

224 SANTIAGO, Silviano. Retórica da verossimilhança. In.: Uma literatura nos trópicos: ensaios sobre dependência cultural. 2. ed. Rio de Janeiro: Rocco, 2000. p. 30-31. 
romântico. Porém, ela aceita casar-se com Luís Garcia, convenientemente movida pela necessidade de preservar a sua dignidade e integridade, acabando, no entanto, por se submeter a uma união orquestrada por Valéria e, com isso, reproduzindo as razões do casamento patriarcal. Já Jorge se interessa primeiro por Estela e depois por Iaiá, deixando-se atrair por mulheres de comportamento aparentemente misterioso, mas também impelido pelo desejo de possuir a figura da agregada e, assim, perpetuando as relações de favor no interior das relações afetivas. Iaiá, por sua vez, ao investir na conquista racionalmente direcionada de Jorge, apaixona-se por ele, com quem se casa unindo interesse e afeto.

Na expressão de Silviano Santiago, o jogo de mari-vaudage empregado por Machado de Assis no romance destaca o casamento como uma mera convenção social que restringe a expansão dos sentimentos. Se casar-se nessa época representava a "aspiração modelar da maior parte das moças" ${ }^{225}$, como sustenta Ingrid Stein, isso significa dizer que a união civil, ao menos para Iaiá Garcia, é uma forma asséptica e rígida, porque, ao final, tanto Estela como Iaiá, decidem-se pelo casamento a partir de uma motivação de interesse social, a despeito serem figuras de temperamentos opostos. Assim, mesmo que a escolha do par amoroso já seja livre, passível de ser feita por vias sentimentais, há sempre algum interesse sob a expressão supostamente espontânea do amor.

O ponto de vista de Machado de Assis, então, confluiu com as observações de Stendhal $^{226}$, que vê no amor um sentimento oriundo do processo social. Para o crítico francês, o amor é o resultado de uma vida que favorece a imaginação, ou ainda, a dissimulação dos sentimentos, isto é, qualquer forma de amar implica decifrar os valores e códigos sociais do sujeito apaixonado. A partir desse princípio, pode-se verificar em Estela a concepção romântica do amor “[...] como algo grandioso, mágico, que atravessa o tempo e o espaço com a força de um bem extra-humano e extramundano"227 e que, na prática, não condiz com os valores de uma sociedade pautada pelo sistema de favor e cooptação. Já em Iaiá, como afirma Bosi, “desejo e interesse não se dissociam. A natural candura e a perfeita dissimulação aparecem juntas [...]"228 na mulher que age racionalmente orientada para a conquista de algum objetivo,

\footnotetext{
${ }^{225}$ STEIN. Ingrid. Op. cit., p. 31.

${ }^{226}$ Cf. STENDHAL. Op. cit.

${ }^{227}$ COSTA, Jurandir Freire. Op. cit., 1998, p. 13.

${ }^{228}$ BOSI, Alfredo. Op. cit.
} 
mas que, por essa via, descobre o amor. Logo, a partir da postura adotada pelas personagens, Machado de Assis sugere que o amor romântico como pressuposto natural ao homem ${ }^{229}$ é uma construção cultural, e, por isso, a convenção moral pode intensificar ou mesmo diluir o sentimento sustentado sobre valores histórico-culturais.

${ }^{229}$ Cf. GAY, Peter. Op.cit. 


\section{REFERÊNCIA BIBLIOGRÁFICA}

ARIÈS, Philippe; DUBY, Georges (Dir.). História da vida privada: da revolução francesa à Primeira Guerra. Tradução Bernardo Joffily; Denise Bottmann. São Paulo: Companhia De Bolso, 2009. v. 4, cap. 4, p. 620.

BOSI, Alfredo. Machado de Assis: o enigma do olhar. São Paulo: Ática, 1999. 228 p.

COSTA, Jurandir Freire. Ordem médica e norma familiar. 5. ed. Rio de Janeiro: Graal, 2004. 282 p.

Sem fraude nem favor: estudos sobre o amor romântico. Rio de Janeiro: Rocco, 1998. 221 p.

DUBY, Georges; PERROT, Michelle (Dir.). Histoire des femmes en Occident : le XIX $^{\mathrm{e}}$ siècle. Paris : Perrin, 2002. v. IV, 765 p.

FAORO, Raymundo. Machado de Assis: a pirâmide e o trapézio. 2. ed. São Paulo: Editora Nacional, 1976. 505 p.

FRANCO, Maria Sylvia de Carvalho. Homens livres na ordem escravocrata. 3. ed. São Paulo: Livraria Kairós, 1983. 235 p.

GAY, Peter. As duas correntes do amor. In. A paixão terna: a experiência burguesa da rainha Vitória a Freud. Tradução Sérgio Flaksman. São Paulo: Companhia Das Letras, 2000. v. 2, p. 45-87.

GLEDSON, John. Machado de Assis e Graciliano Ramos: especulações sobre sexo e sexualidade. In: Por um novo Machado de Assis: ensaios. Tradução Frederico Dentello. São Paulo: Companhia Das Letras. 2006. cap. 11, p. 312-334.

LEITE, Dante Moreira. Lucíola: teoria romântica do amor. In: O amor romântico e outros temas. 2. ed. São Paulo: Editora Nacional / Edusp, 1979. p. 54-58.

MACHADO DE ASSIS. Machado de Assis: obra completa em quatro volumes. Organização Aluizio Leite et al. 2. ed. Rio de Janeiro: Nova Aguilar, 2008. v. 1, 1340 p. (Fortuna Crítica / Romances). 
Instinto de nacionalidade. In:

Obra completa: crítica literária.

Organização Henrique de Campos. São Paulo: Editora Mérito, 1959. p. 129-141.

O primo Basílio, por Eça de Queirós. In:

Obra completa: crítica

literária. Organização Henrique de Campos. São Paulo: Editora Mérito, 1959. p. 154179.

MURICY, Katia. A razão cética: Machado de Assis e as questões do seu tempo. São Paulo: Companhia Das Letras, 1988. 140 p.

PEREIRA, Astrojildo. Romancista do Segundo Reinado. In: Machado de Assis: ensaios e apontamento avulsos. Rio de Janeiro: Livraria São José, [1959]. p. $11-42$.

RENAULT, Delso. Rio de Janeiro: a vida da cidade refletida nos jornais (18501870). São Paulo: Civilização Brasileira, 1978. 317 p.

ROMANCES EM HIPERTEXTO: Iaiá Garcia: Banco de dados preparado por Marta de Senna. In: FUNDAÇÃO CASA DE RUI BARBOSA. Machado de Assis.net: no ar desde $2007 . \quad$ Disponível em: <http://www.machadodeassis.net/hiperTx_romances/obras/iaiagarcia.htm> Acesso em: 9 Jan. 2011.

SCHWARZ, Roberto. Ao vencedor as batatas: forma literária e processo social nos inícios do romance brasileiro. 5. ed. São Paulo: Livraria Duas Cidades / Editora 34, 2000. 236 p. (Coleção Espírito Crítico).

SOUZA, Ronaldes de Melo e. O romance tragicômico de Machado de Assis. Rio de Janeiro: EdUERJ, 2006. 192 p.

STAËL-HOLSTEIN, Anne Louise Germaine de. De la littérature : considérée dans ses rapports avec les instituitions sociales. [Paris: s.n.], 1800. 398 p. (Livro digitalizado a partir do original da Oxford Universtiy). Disponível em: $<$ http://books.google.com.br/books?id=EnAGAAAAQAAJ\&printsec=frontcover\&dq= De+La+litt\%C3\%A9rature+:+consid\%C3\%A9r\%C3\%A9e+dans+les+rapports+avec+le s+institutions+sociales\&hl=pt-BR\&ei $=1$ -

FETen2DozJcZvkpYEO\&sa $=X \&$ oi=book result\&ct $=$ result\&resnum $=2 \& v e d=0 C C 4 Q 6$ AEwAQ\#v=onepage\&q\&f=false $>$ Acesso em: 4 Fev. 2011.

STEIN, Ingrid. Figuras femininas em Machado de Assis. Rio de Janeiro: Paz e Terra, 1984. 146 p. (Coleção Literatura e Teoria Literária). 
STENDHAL. Do amor. Tradução Roberto Leal Pereira. 2. ed. São Paulo: Martins Fontes, 1999. 379 p.

WEBER, Max. Economia e sociedade: fundamentos da sociologia compreensiva. Tradução Regis Barbosa e Karen Elsabe Barbosa. 5 ed. Brasília: UnB, 2009.

ZOLA, Emile. O romance experimental e o naturalismo no teatro. Tradução Italo Caroni; Célia Berrettini. 2. ed. São Paulo: Perspectiva, 1982. 138 p. 